\author{
UNIVERSIDADE DE SÃO PAULO \\ ESCOLA DE ENGENHARIA DE SÃO CARLOS \\ DEPARTAMENTO DE HIDRÁULICA E SANEAMENTO \\ PROGRAMA DE PÓS-GRADUAÇÃO EM CIÊNCIAS DA ENGENHARIA \\ AMBIENTAL
}

\title{
“AVALIAÇÃO DA QUALIDADE DE SEDIMENTOS DOS RIOS TIETÊ E PIRACICABA NOS SEUS COMPARTIMENTOS DE ENTRADA NO RESERVATÓRIO DE BARRA BONITA, SP ."
}

\section{Julieta Bramorski}

Dissertação apresentada à Escola de Engenharia de São Carlos, da Universidade de São Paulo, como parte dos requisitos para a obtenção do título de Mestre em Ciências da Engenharia Ambiental

Orientador: Prof. Dr. Swami Marcondes Villela

São Carlos-SP

2004 
Dedico:

Aos meus pais, Claudio e Aurea Bramorski, pelo amor e compreensão 


\section{AGRADECIMENTOS}

Ao Prof. Dr. Swami Marcondes Villela, pelos ensinamentos, pela ajuda constante, pela amizade e, principalmente pela confiança na realização deste trabalho.

Ao Prof. Dr. Adilson Pinheiro, que sempre acreditou em mim e me ensinou os primeiros "passos" do universo científico, e pelas grandes sugestões que mudaram (para melhor) a minha vida.

Aos professores Dr. Evaldo Luiz Gaeta Espíndola e Dr. Sílvio Crestana, membros da banca de qualificação, pelas valiosas contribuições. Em particular ao Prof. Dr. Evaldo Luiz Gaeta Espíndola, pelo auxílio na realização da coleta de campo e outros tantos auxílios ao trabalho em geral. Ao Prof. Dr. Luís Daniel, pela ajuda prestada na realização das análises microbiológicas.

Ao CNPq, pela bolsa de estudos.

À FAPESP, pelo auxílio à pesquisa (Processo 2003/01301-2).

À Financiadora de Estudos e Projetos (FINEP) através do Projeto CT-HIDRO 2001, que financiou parte das atividades de coleta de dados e análise de laboratório - Convênio FINEP com a FIPAI (Fundação de Incremento à Pesquisa e o Aperfeiçoamento Industrial), processo: 23.01.0606.00.

Ao Prof. Dr. Antônio Mozeto, que cedeu as instalações do laboratório para a realização da análise de cronologia e ao Dr. Raul Cazotti pela realização das mesmas e auxílios na discussão dos resultados.

Aos técnicos do CRHEA: Amândio Menezes Nogueira, Marcelo Menezes Nogueira e Luci A. Queiroz.

Aos companheiros de coleta: Alessandro Minillo, Viviane Faria de Miranda e ao técnico Valdomiro Antônio Filho. 
Aos amigos: Érica, Andréia, Dayani, Vivi, Aline, Ricardo, Domingos, Vitinho, King, entre tantos outros, que fizeram estes dois anos de trabalho muito mais agradáveis. Agradeço por tudo: pela companhia, ajuda, festas, desabafos, etc.

Aos amigos companheiros de moradia, Carol e Maurício, pela amizade, pela ajuda na dissertação e por proporcionar um lar tão harmonioso, muito importante para a conclusão deste trabalho.

À Samuel Coelho Rodrigues, pelo amor, carinho, respeito, compreensão, paciência... 


\section{SUMÁRIO}

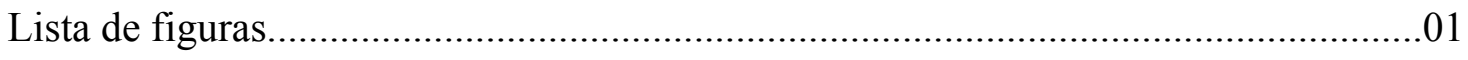

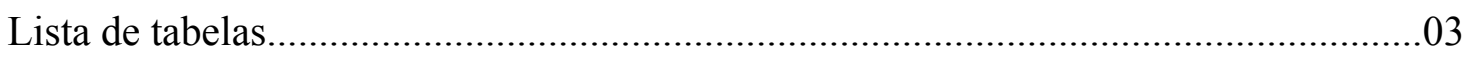

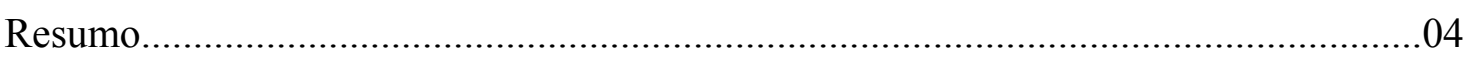

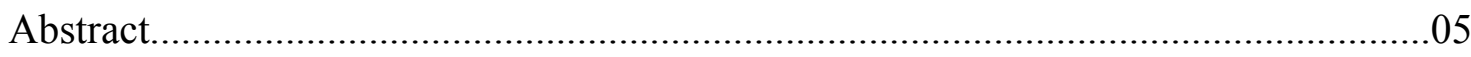

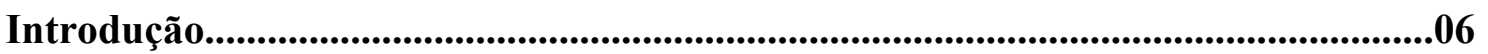

Capítulo 1...................................................................................................................................11

Caracterização geral da área de estudo

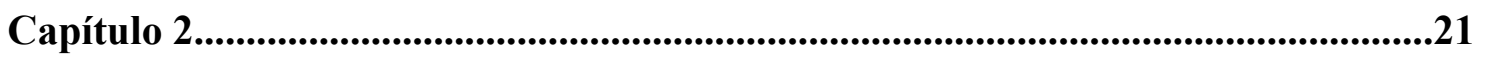

Contaminação dos sedimentos por metais nos rios Tietê e Piracicaba, nos seus compartimentos de entrada no Reservatório de Barra Bonita- SP.

Capítulo 3

Estoque de nutrientes (nitrogênio e fósforo total) nos sedimentos

dos rios Tietê e Piracicaba, nos seus compartimentos de entrada no Reservatório de Barra Bonita-SP

Capítulo 4 . .88

Avaliação ecotoxicológica dos sedimentos dos rios Tietê e Piracicaba, nos seus compartimentos de entrada no Reservatório de Barra Bonita- SP

Capítulo 5

Densidade de microorganismos de interesse público (Coliformes fecais) em sedimentos recentes dos rios Tietê e Piracicaba, nos seus compartimentos de entrada no reservatório de Barra Bonita- SP.

Capítulo 6.

Considerações finais 


\section{LISTA DE FIGURAS}

Figura 01: Bacia Hidrográfica do Médio Tietê Superior (SP) e suas sub-bacias.............16

Figura 02: Mapa de localização do Reservatório de Barra Bonita-SP ............................17

Figura 03: Vista de jusante da barragem do Reservatório de Barra Bonita....................18

Figura 04: Concentração de Ferro total no perfil de sedimento, nas diferentes estações de coleta.

Figura 05: Concentração de Manganês total no perfil de sedimento, nas diferentes estações de coleta.

Figura 06: Concentração de Cobre total no perfil de sedimento, nas diferentes estações de coleta.

Figura07: Concentração de Cádmio total no perfil de sedimento, nas diferentes estações de coleta.

Figura 08: Concentração de chumbo total no perfil de sedimento, nas diferentes estações de coleta.

Figura 09: Concentração de níquel total no perfil de sedimento, nas diferentes estações de coleta.

Figura 10: Concentração de ferro potencialmente biodisponível no perfil de sedimento, nas diferentes estações de coleta. .40

Figura 11: Concentração de manganês potencialmente biodisponível no perfil de sedimento, nas diferentes estações de coleta.

Figura 12: Concentração de zinco potencialmente biodisponível no perfil de sedimento, nas diferentes estações de coleta.

Figura 13: Concentração de cobre potencialmente biodisponível no perfil de sedimento, nas diferentes estações de coleta.

Figura 14: Concentração de cádmio potencialmente biodisponível no perfil de sedimento, nas diferentes estações de coleta.

Figura 15: Concentração de cromo potencialmente biodisponível no perfil de sedimento, nas diferentes estações de coleta.

Figura 16: Concentração de chumbo potencialmente biodisponível no perfil de sedimento, nas diferentes estações de coleta.

Figura 17: Concentração de níquel potencialmente biodisponível no perfil de sedimento, nas diferentes estações de coleta. .56 
Figura 18: Cluster formado a partir do agrupamento das amostras de acordo com a biodisponibilização de metais. .60

Figura 19: Rendimento de ${ }^{210} \mathrm{~Pb}$, em função da profundidade, no perfil de sedimento da estação 5 (rio Tietê). .63

Figura 20 : Geocronologia do perfil de sedimentos da Estação 5 (rio Tietê). .63

Figura 21: Concentração de nitrogênio total no perfil dos sedimentos dos compartimentos iniciais do Reservatório de Barra Bonita (rio Piracicaba e Tietê).......78

Figura 22: Concentração de fósforo total no perfil dos sedimentos dos compartimentos iniciais do Reservatório de Barra Bonita (rio Piracicaba e Tietê)..................................80

Figura 23: Daphnia similis (2,0- 2,7 mm), (Cladocera, Crustaceo).............................91

Figura 24: Chironomus xanthus (Chironomidae, Diptera)..........................................92 Figura 25: Densidade de bactérias nos sedimentos das diferentes estações de coleta...106 Figura 26: Abundância relativa de microrganismos nos sedimentos das diferentes estações de coleta. 108

Figura 27: Cluster da densidade de microrganismos presentes nos sedimentos, em cada estação de coleta 110 


\section{LISTA DE TABELAS}

Tabela 01: Características gerais do Reservatório de Barra Bonita 14

Tabela 02: Municípios selecionados para a pesquisa de uso e ocupação dos solos ao longo dos rios Piracicaba e Tietê

Tabela 03: Relação entre as concentrações de ferro total e potencialmente biodisponível obtidas em amostras de sedimento do Reservatório de Barra Bonita.

Tabela 04: Relação entre as concentrações de manganês total e potencialmente biodisponível obtidas em amostras de sedimento do Reservatório de Barra Bonita.......44 Tabela 05: Relação entre as concentrações de cádmio total e potencialmente biodisponível obtidas em amostras de sedimento do Reservatório de Barra Bonita........50 Tabela 06: Relação entre as concentrações de chumbo total e potencialmente biodisponível obtidas em amostras de sedimento do Reservatório de Barra Bonita.......54 Tabela 07: Relação entre as concentrações de níquel total e potencialmente biodisponível obtidas em amostras de sedimento do Reservatório de Barra Bonita.......57 Tabela 08: Relação dos principais componentes da análise de PCA, e percentual da variância explicada...... .58

Tabela 09: Data correspondente de cada camada de sedimento no perfil da estação 5 (rio Tietê).

Tabela 10 - Teste de toxicidade aguda com Daphnia similis com sedimento solubilizado. .93

Tabela 11: Teste de toxicidade aguda com Chironomus xanthus com sedimento total. 


\section{RESUMO}

BRAMORSKI,J. Avaliação da qualidade de sedimentos dos rios Tietê e Piracicaba no compartimento de entrada do Reservatório de Barra Bonita, SP." São Carlos 2004.135p. Dissertação (mestrado)- Escola de Engenharia de São Carlos, Universidade de São Paulo.

Ao longo das últimas décadas, o Reservatório de Barra Bonita vem sofrendo com a degradação da qualidade de suas águas, uma vez que os seus principais tributários (rios Piracicaba e Tietê) estão inseridos em regiões de alto desenvolvimento antrópico. O monitoramento da qualidade das águas vem sofrendo mudanças substanciais, ao considerar o sedimento como um sítio integrador dos processos ocorridos na coluna d'água e uma fonte contínua de poluição, já que em algumas condições pode haver ressuspensão de poluentes e/ou contaminantes. Neste sentido, este trabalho teve por objetivo a avaliação qualitativa dos sedimentos dos principais compartimentos iniciais (rios Piracicaba e Tietê), sob aspectos físicos, químicos e biológicos, considerando a destinação da água para abastecimento público e produção de energia elétrica e a inserção destes compartimentos no ecossistema do reservatório. Foram coletadas amostras ao longo de cada tributário desde o início do represamento até a região de confluência, e analisadas as concentrações de metais totais e biodisponíveis, nutrientes, matéria orgânica, granulometria, efeito tóxico sobre organismos-teste, densidade de microrganismos de interesse público e levantamento do uso e ocupação dos solos da bacia, a partir de 1960. Verificou-se, a partir da implantação do reservatório, intensas mudanças no cenário urbano, resultante do êxodo rural, com acelerado processo de industrialização nas regiões de influência do reservatório. Os resultados indicam o rio Tietê como sendo o mais intensamente afetado por estas atividades, apresentando altas concentrações de nutrientes, alta densidades de indicadores de contaminação de origem fecal, alta poluição por metais $(\mathrm{Mn}, \mathrm{Cd}, \mathrm{Pb}$ e $\mathrm{Ni})$ sendo grande parte deste de alta mobilidade, ou seja, fracamente aderidos as partículas de sedimento, representando toxicidade para os organismos teste utilizados (Daphnia similis e Chironomus xanthus). Desta forma, os sedimentos representam uma fonte contínua de degradação da qualidade das águas deste sistema, causando prejuízos de ordem social, econômica e ambiental.

Palavras-chave: Reservatório de Barra Bonita, rio Tietê, rio Piracicaba, qualidade de sedimentos. 


\begin{abstract}
BRAMORSKI, J. "Sediments quality evaluation of Tietê and Piracicaba rivers in the entrance compartments of Barra Bonita reservoir's." São Carlos 2004.135p.
\end{abstract} Dissertation (master's degree) - Escola de Engenharia de São Carlos, Universidade de São Paulo

Along the last decades, Barra Bonita reservoir has been suffering with its water quality degradation, once its major's tributaries (Piracicaba and Tietê rivers) are inserted in high anthropic development regions. The monitoring of the water quality has suffered substancial changes, when considering the sediment as an integrator site of the processes ocurred in the water column and as a continued form of polution, since in some conditions there may be polutents and/or contaminents ressuspension. In this way, the work had as an objective the sediments qualitative evaluation of the major initial compartments (Piracicaba and Tietê rivers), under physical, chemical and biological aspects, considering the destination of the water public supply and the electrical energy production and these compartments insertion into the reservoir's ecosystem. Samples were colected along each tributary from the begining of the restraining area until the confluence region, and analysed the total and bioavailable metals, nutrients, organic matter, granulating metry, toxicant effect over test-organisms, public interest microrganisms density and recognization of the basin soil's use and occupation, since 1960. It was found, that due to the reservoir implantation, intense changes in the urban scenery, resulting from rural exodus, with accelerated industrialization process in the reservoir influence regions. The results indicate river Tietê as being the most intensively affected by these activities, presenting high nutrients concentration, high density of fecal origem contaminators indicators, high polution by metals $(\mathrm{Mn}, \mathrm{Cd}, \mathrm{Pb}, \mathrm{Ni})$, being in the greater part of high mobility ones, so, weakly adhered to sediment particles, representing toxicity to the test-organisms used (Daphnia similis and Chironomus xanthus). This way, the sediments represent a continuous source of the system water quality degradation, causing damage to social, economical and enviromental orders.

Key-words: Barra Bonita reservoir, Tietê river, Piracicaba river, sediments quality 


\section{INTRODUÇÃO}

No contexto nacional, o Estado de São Paulo tem ocupado posição de destaque no que tange ao desenvolvimento, em relação aos outros estados. Além disso, destaca-se também no que se refere à qualidade das ciências desenvolvidas em seu território, tendo servido como modelo para diversas regiões do país.

No entanto, devido ao progresso acelerado surgiram necessidades reais de alguns procedimentos que assegurassem a sustentabilidade ambiental de seus ecossistemas. Desta forma, diversas obras de engenharia foram implantadas com o intuito de satisfazer a demanda necessária à sobrevivência e ao desenvolvimento da região. Neste âmbito, destacam-se os inúmeros reservatórios construídos no estado, sendo que, muitos destes, acabaram não passando por um planejamento adequado, alheio a realidade circundante.

Todos os reservatórios formados por represas no Estado de São Paulo são recentes, a maioria deles com menos de 50 anos, destacando-se por sua importância os reservatórios de: Barra Bonita, Bariri, Ibitinga, Três Irmãos, Jupiá, Ilha Solteira, Porto Primavera, Salto Grande, Lobo, Guarapiranga, entre outros.

A vida útil de um reservatório varia desde alguns poucos anos até centenas de anos, sendo o fator determinante para tal variação o seu enchimento por sedimentos. Um estudo do Banco Mundial mostrou que a vida útil média dos reservatórios existentes em todos os países no mundo decresceu de 100 para 22 anos, tendo sido avaliado em 6 bilhões de dólares anuais o custo para promover a remoção dos volumes que vão sendo assoreados. Ficou demonstrado também que a perda média anual de volume dos reservatórios devido ao depósito de sedimentos era de $1 \%$, sendo variável de um país para outro, bem como de região para região (MAHMOOD,1987, apud CARVALHO, 2000). A perda anual de capacidade de armazenamento dos reservatórios brasileiros é de aproximadamente $0,5 \%$. Constata-se ainda que a erosão no país tem aumentado com o crescimento da população e do uso do solo (CARVALHO, 1994). Assim, o planejamento do reservatório deve prever a viabilidade da obra em função do seu uso.

A construção de reservatórios altera o fluxo dos rios no qual é implantado, gerando transformações tanto no ecossistema aquático como no ecossistema terrestre, 
de forma efetiva. No entanto, traz benefícios como a reserva de água para hidroeletricidade, irrigação, navegação e abastecimento público.

Ao longo da década de 50, o industrialismo firmou-se como ideologia dominante na América Latina, constituindo-se no argumento central de um conjunto heterogêneo de forças sociais favoráveis ao desenvolvimento capitalista. O fortalecimento da indústria de energia era condição indispensável para que os demais investimentos fossem viabilizados (construção de rodovias, industrialização), com vistas ao desenvolvimento (VALÊNCIO et al., 1999).

Desta forma, em 1956 foi apresentado o projeto de construção da Usina Hidroelétrica de Barra Bonita, vindo a cumprir a missão do desenvolvimento regional, tão ensejado pelo Estado. Em 1963, no dia 20 de maio deu-se início ao funcionamento da usina.

Concomitantes ao desenvolvimento, novos arranjos de uso e ocupação dos solos foram se estabelecendo na região de Médio Tietê Superior e bacia do rio Piracicaba. As práticas agrícolas sofreram mudanças substanciais, já que com a mecanização do campo o êxodo rural se intensificou e o cenário urbano transformou-se nitidamente. $\mathrm{O}$ desenvolvimento industrial inseriu grande quantidade de compostos e resíduos sintéticos ao meio ambiente (POSTEL, 1987) e os centros urbanos passaram a contribuir com altas cargas de despejos domésticos, sendo os recursos hídricos os principais destinatários e os mais intensamente afetados.

Ao longo das últimas décadas, o Reservatório de Barra Bonita vem sofrendo com a degradação da qualidade de suas águas. O acelerado grau de eutrofização do reservatório deprecia os terrenos marginais (poluição visual e mau cheiro), compromete a recreação e gera prejuízos ao funcionamento da usina hidroelétrica, além dos problemas ambientais originários deste processo (inviabilização da vida aquática). De acordo com MOZETO (2001), a avaliação da qualidade da água tem sofrido grandes transformações do ponto de vista da concepção de programas de monitoramento. Essa mudança de paradigma que, fundamentalmente vem ocorrendo, adota uma nova abordagem que inclui a avaliação da qualidade dos sedimentos, um compartimento que era, até pouco tempo, apenas considerado como um acumulador de nutrientes e contaminantes.

O compartimento sedimento é o sítio integrador de vários processos que ocorrem na coluna d'água e a determinação de sua qualidade torna-se de fundamental importância em estudos ambientais. O corpo hídrico é reflexo de sua bacia de drenagem 
e os impactos gerados hoje repercutirão por muitos anos (PAIVA \& PAIVA,2001), considerando que os sedimentos do fundo de rios, lagos e reservatórios atuam como depósito de substâncias muitas vezes nocivas ao ecossistema aquático e que se processam, transformam e podem, efetivamente, retornar a coluna d'água. $\mathrm{O}$ depósito sedimentar pode fornecer dados históricos de atividades ocorridas na bacia circundante em função do seu uso e ocupação (SALOMONS \& FORSTNER ,1984). Apesar da importância dos depósitos de sedimentos na qualidade dos recursos hídricos, apenas recentemente este compartimento vem sendo considerado de alta prioridade em estudos ambientais.

Reservatórios são sistemas híbridos entre rios e lagos e seu estudo deve levar em consideração esta característica (THORNTON et al., 1990). Além disso, no Brasil, grande parte dos reservatórios apresentam padrão morfométrico do tipo dentritico, acarretando a formação de braços laterais. Segundo OLIVEIRA (1993), estes braços, na maioria das vezes, atuam como compartimentos distintos e, como sub-sistemas, apresentam características próprias que devem ser consideradas, já que confere ao sistema um maior grau de heterogeneidade espacial. O reservatório de Barra Bonita apresenta estas características e seus principais tributários, os rios Piracicaba e Tietê, atuam como grandes compartimentos distintos, mas que possuem relação direta com o corpo hídrico central. Estes rios percorrem uma das regiões mais populosas e desenvolvidas do Estado de São Paulo, e são os principais responsáveis pela degradação da qualidade das águas do reservatório.

Desta forma, a investigação da qualidade dos sedimentos destes tributários, nos compartimentos iniciais do reservatório de Barra Bonita, fornece um diagnóstico atual da contaminação ambiental, identificando os locais mais críticos, podendo subsidiar programas de recuperação e monitoramento da qualidade da água.

O presente estudo teve por objetivo a avaliação qualitativa dos sedimentos dos principais compartimentos iniciais do reservatório de Barra Bonita (rios Piracicaba e Tietê), considerando variáveis físicas, químicas e biológicas, considerando a destinação da água para abastecimento público, a produção de energia elétrica e a inserção destes compartimentos no reservatório. 


\section{ESTRUTURA DO TRABALHO}

Este trabalho foi organizado em 6 seções, de modo a apresentar o universo de dados obtidos de forma mais precisa e organizada.

No capítulo 1 apresenta-se uma descrição detalhada sobre a área de estudo, caracterizando a região do Médio Tietê Superior, a bacia do rio Piracicaba e o próprio reservatório, considerando o reflexo que as áreas de entorno representam sobre a qualidade dos recursos hídricos e, consequentemente sobre sedimentos de fundo de ambientes aquáticos.

No capítulo 2 procurou-se caracterizar os sedimentos quanto a presença e concentração de metais aderidos fortemente às partículas ou na forma lábil, juntamente com uma análise detalhada sobre o uso e ocupação dos solos após a implantação do reservatório, mostrando as transformações nas áreas urbanas e rurais e o crescimento industrial de alguns municípios da região.

O capítulo 3 consiste na determinação dos estoques de nutrientes nas camadas sedimentares, considerando o acelerado e evidente processo de eutrofização das águas do reservatório. A possibilidade de identificação dos locais mais influenciados pelos despejos domésticos e sua relação com o crescimento demográfico das últimas décadas, fornece dados importantes e necessários em planos de manejo integrado neste sistema.

No capítulo 4 procurou-se abordar os estudos ecotoxicológicos dos sedimentos do reservatório de Barra Bonita, por meio da utilização de organismos-teste. Estes dados comprovam a existência, ou não, de níveis de poluentes potencialmente deletérios para a biota aquática.

O capítulo 5 consiste na determinação da densidade de alguns microorganismos de interesse público nos sedimentos, abordando ainda suas relações com a coluna d'água e a saúde humana.

Uma síntese das informações e conclusões obtidas nos capítulos anteriores e suas inter-relações, integrando os resultados de modo a apresentar conectividade entre os assuntos abordados, visando o objetivo proposto, é apresentado no capítulo 6 . 


\section{REFERÊNCIAS BIBLIOGRÁFICAS}

CARVALHO, N. O. (1994). Hidrossedimentologia prática. CPRM, Eletrobrás. Rio de Janeiro, RJ.

CARVALHO, N. O. (2000). Guia de práticas sedimentométricas. Brasília:ANEEL, Superintendência de estudos e informações hidrológicas. 154p.

MOZETO, A. A (2001). Workshop de avaliação do projeto qualised: bases técnicocientíficas para o desenvolvimento de critérios de qualidade de sedimentosexperimentos de campo e laboratório. São Carlos: UFSCAR 69p.

OLIVEIRA, H. T.(1993). Avaliação das condições limnológicas de um compartimento (Braço do Rio Capivara) e sua interação com o reservatório de Barra Bonita, SP., com ênfase na comunidade fitoplantônica. Tese (Doutorado), EESC/USP,328p.

PAIVA, E. M. C. D; PAIVA, J. B. D. (2001) Caracterização quali-quantitativa da produção de sedimentos. Santa Maria: ABRH: UFSM, 436 p.

POSTEL, S. (1987). Defusing the toxics threat: controlling pesticides and industrial waste. Worldwatch paper 79. Worldwatch institute, Washington,D.C. 69p.

SALOMONS, W. \& FORSTNER, U. (1984). Metals in the hidrocycle. SpringerVerlag, Berlin.349 p.

THORNTON, K. W; KIMMEL, L. B; FONEST, E. P. (1990). Reservoir limnology: ecological perspectives. New York, John Wiley. 246p.

VALÊNCIO, N. F. L. S; GONÇALVES, J. C; VIDAL, K. C; MARTINS, R. C;

RIGOLIN, M. V; LOURENÇO, L. C; MENDONÇA, S. A. T.; LEME, A. A. (1999).

O papel das hidroelétricas no processo de interiorização paulista: o caso das usinas hidroelétricas de Barra Bonia e Jurumirim. In: HENRY, R. Ecologia de reservatórios: estrutura, função e aspectos sociais. Botucatu: FUNDBIO:FAPESP, $626 \mathrm{p}$. 


\section{Capítulo 1}

\section{"Caracterização geral da área de estudo"}

\section{LOCAL DE ESTUDO}

A área de estudo abrange os principais compartimentos iniciais do reservatório de Barra Bonita, representados pelo rio Piracicaba (Bacia do rio Piracicaba) e rio Tietê (Bacia do Médio Tietê Superior). O interesse está direcionado para a região de transição entre os ambientes lóticos dos rios e o ambiente lêntico, gerado pelo represamento das águas próximo ao local de confluência dos rios Piracicaba e Tietê, dentro do Reservatório de Barra Bonita.

Utilizando-se os estudos de OLIVEIRA (1993), ESPÍNDOLA (1994). OISHI (1996) e COSTA (2001), procurou-se caracterizar a área de estudo.

\subsection{BACIA DO MÉDIO TIETÊ SUPERIOR}

A bacia hidrográfica em questão abrange o trecho do rio Tietê desde o Reservatório de Pirapora do Bom Jesus até o Reservatório de Barra Bonita (Figura 01), percorrendo uma extensão de $270 \mathrm{~km}$ (até a barragem). Estima-se que grande parte da contaminação das águas do Médio Tietê seja proveniente do transporte de poluentes da 
Bacia do Alto Tietê. Existem inúmeros afluentes ao longo de seu curso, podendo-se citar os rios do Peixe, Capivara e Aguapé.

Quanto ao uso do solo, divide-se entre os típicos de áreas urbanas e as atividades rurais (encontram-se plantações de cana de açúcar, café, Citrus, hortaliças e frutas, pastagens cultivadas e pastagens naturais; matas, capoeiras, reflorestamento e atividades granjeiras). As principais atividades industriais poluentes são: têxteis, de papel e papelão, engenhos e usina de açúcar e álcool, entre outros. A água dos rios é utilizada para abastecimento público, afastamento de efluentes domésticos, abastecimento industriais e lançamentos de efluentes industriais (CETESB, 1999).

No reservatório de Barra Bonita ocorre a extração de areia para construção civil e argila. Quase toda a área inundada pelo reservatório é atingida por esta atividade. Esta extração é feita por meio de dragagem do leito do rio e bombeamento do material para tanques colocados nas margens.

\subsection{BACIA DO RIO PIRACICABA}

A bacia do rio Piracicaba (Figura 01) engloba grandes centros urbanos, dos quais destacam-se os municípios de Americana, Limeira e Campinas. Seus principais afluentes são os rios Atibaia, Jaguari e Piracicaba. O rio Piracicaba, objeto de análise neste estudo, encontra-se com o rio Tietê onde formam o Reservatório de Barra Bonita, após percorrer $115 \mathrm{Km}$ (até a barragem). Apresenta alto desenvolvimento industrial, entre as quais indústrias de papel e celulose, têxteis, metalúrgicas, usinas de álcool, entre outras.

Entre as principais causas de sua poluição, além daquela gerada pelos municípios que engloba, deve-se considerar a geração de poluentes pelos rios Atibaia e Jaguari, além do processo de reversão de suas águas para a cidade de São Paulo (THAME, 1998 apud COSTA, 2001). 


\section{O RESERVATÓRIO DE BARRA BONITA}

O reservatório de Barra Bonita (Figura 02) é o primeiro da série de reservatórios construídos em cascata no rio Tietê, localizando-se em uma das regiões mais populosas e desenvolvidas do interior do Estado de São Paulo. A barragem foi construída na década de 60, com funcionamento a partir de 20 de maio de 1963. De acordo com CALIJURI (1988), a barragem localiza-se a 22²9’S e $48^{\circ} 34^{\prime} \mathrm{W}$, entre os municípios de Barra Bonita e Igaraçu, na bacia do médio Tietê, a 430 metros de altitude. A sua formação ocorreu a partir do represamento das águas dos rios Tietê e Piracicaba, além de inúmeros tributários que drenam suas águas para esses dois rios de maior importância.

A região está inserida em uma área de transição entre os climas tropical e subtropical, não apresentando estações climáticas bem definidas, sendo os marcadores sazonais mais nítidos o período chuvoso (verão) e seco (inverno), conforme mencionado por CALIJURI (1998).

O reservatório de Barra Bonita, além de ser um importante recurso hídricoenergético, é destinada a múltiplos fins, tais como transporte fluvial, irrigação, piscicultura, recreação e abastecimento de água. O reservatório também é utilizado como corpo receptor dos despejos domésticos e industriais, principalmente do beneficiamento da cana-de-açúcar. Quanto à vegetação, predomina a monocultura 
intensiva de cana-de-açúcar no entorno do reservatório, contribuindo para o carreamento de material particulado para dentro da represa (ESPÍNDOLA,1994)

De acordo com COSTA (2001), a partir de 1983 observou-se um significativo aumento no processo de eutrofização do reservatório, quando se optou pelo menor recalque dos esgotos da cidade de São Paulo para a Represa Billings (através da inversão do Rio Pinheiros) e o lançamento destes no Tietê.

Algumas informações gerais do reservatório de Barra Bonita sãp apresenatdos na Tabela 01.

Tabela 01: Características gerais do Reservatório de Barra Bonita.

\begin{tabular}{|l|l|}
\hline Extensão da barragem & $480 \mathrm{~m}$ \\
\hline Área do reservatório & $329,12 \mathrm{Km}^{2}$ \\
\hline Volume total do reservatório & $3.160 \times 106 \mathrm{~m}^{3}$ \\
\hline Descarga total do vertedouro & $4.200 \mathrm{~m}^{3} / \mathrm{s}$ \\
\hline Superfície da Bacia Hidrográfica & $32.330 \mathrm{Km}^{2}$ \\
\hline Área inundada & $324,84 \mathrm{Km}^{2}$ \\
\hline Perímetro aproximado & $525 \mathrm{Km}$ \\
\hline Profundidade máxima & $25 \mathrm{~m}$ \\
\hline Profundidade média & $10,2 \mathrm{~m}$ \\
\hline Volume útil & $2.600 \times 10^{6} \mathrm{~m}^{3}$. \\
\hline
\end{tabular}

Em relação às características limnológicas, o reservatório apresenta padrão de circulação do tipo polimítico, com curtos períodos de estratificação, encontrando-se em adiantado estado de eutrofização. O tempo médio de retenção da águas é de 30 dias no verão e 6 meses no inverno (TUNDISI \& MATSUMURA-TUNDISI, 1990). 
Dentre os diversos tributários do sistema, os rios Piracicaba e Tietê são os principais responsáveis pelo estado trófico do reservatório, fornecendo altas cargas de nutrientes e metais através dos despejos domésticos e industriais (OISHI, 1996 e COSTA, 2001).

Devido a elevada carga de nutrientes, extensos bancos de macrófitas aquáticas (Eichornia sp, Paspalum sp e Pistia sp) são encontrados no reservatório, o que é uma característica de ambientes eutrofizados, sendo que as plantas exercem efeito adicional na dinâmica do sistema. PETRACCO (1995), por exemplo, realizando estudos em bancos de duas espécies de macrófitas no reservatório, verificou diferenças acentuadas dentro e fora dos bancos: a estratificação térmica da coluna de água apresentou valores mais baixos de oxigênio dissolvido dentro dos bancos, assim como material em suspensão orgânico e total mais elevado. As concentrações de nitrato e amônio foram em geral superiores na água de fora dos bancos, ocorrendo o inverso com a concentração de fósforo total. Este estudo demonstrou a relevância das macrófitas no metabolismo de reservatórios, especialmente em relação à qualidade da água e à carga interna de nutrientes no sistema.

Fatores hidrológicos e meteorológicos influenciam fortemente a dinâmica e a ecologia do reservatório. De acordo com SANDES (1998), por meio de estudos sobre os fatores responsáveis pelo desencadeamento do florescimento de Mycrocystis aeruginos, a velocidade e direção do vento, o vento associado e outros fatores, como a alta temperatura do ar e alto tempo de residência hidráulica foram determinantes para o florescimento. MARQUISÁ (1998), verificou através de um estudo comparativo entre dois reservatórios (Broa e Barra Bonita), que a composição do material sedimentar varia em função das diferentes características das bacias e estado trófico dos reservatórios.

\subsection{ATIVIDADES DE PESQUISA}

O reservatório de Barra Bonita (Figura 03) está entre os sistemas mais intensivamente estudados no país, com início das pesquisas em 1979. Entre os primeiros trabalhos destaca-se o projeto "Tipologia de Represas do Estado de São Paulo", financiado pela FAPESP- Fundação de Amparo à Pesquisa do Estado de São Paulo 
(MATSUMURA-TUNDISI,1983). Vários outros trabalhos foram desenvolvidos a partir desta data, como os de: TUNDISI (1981), HENRY et al (1983), ESPÍNDOLA (1994), e MARQUISÁ (1998). 


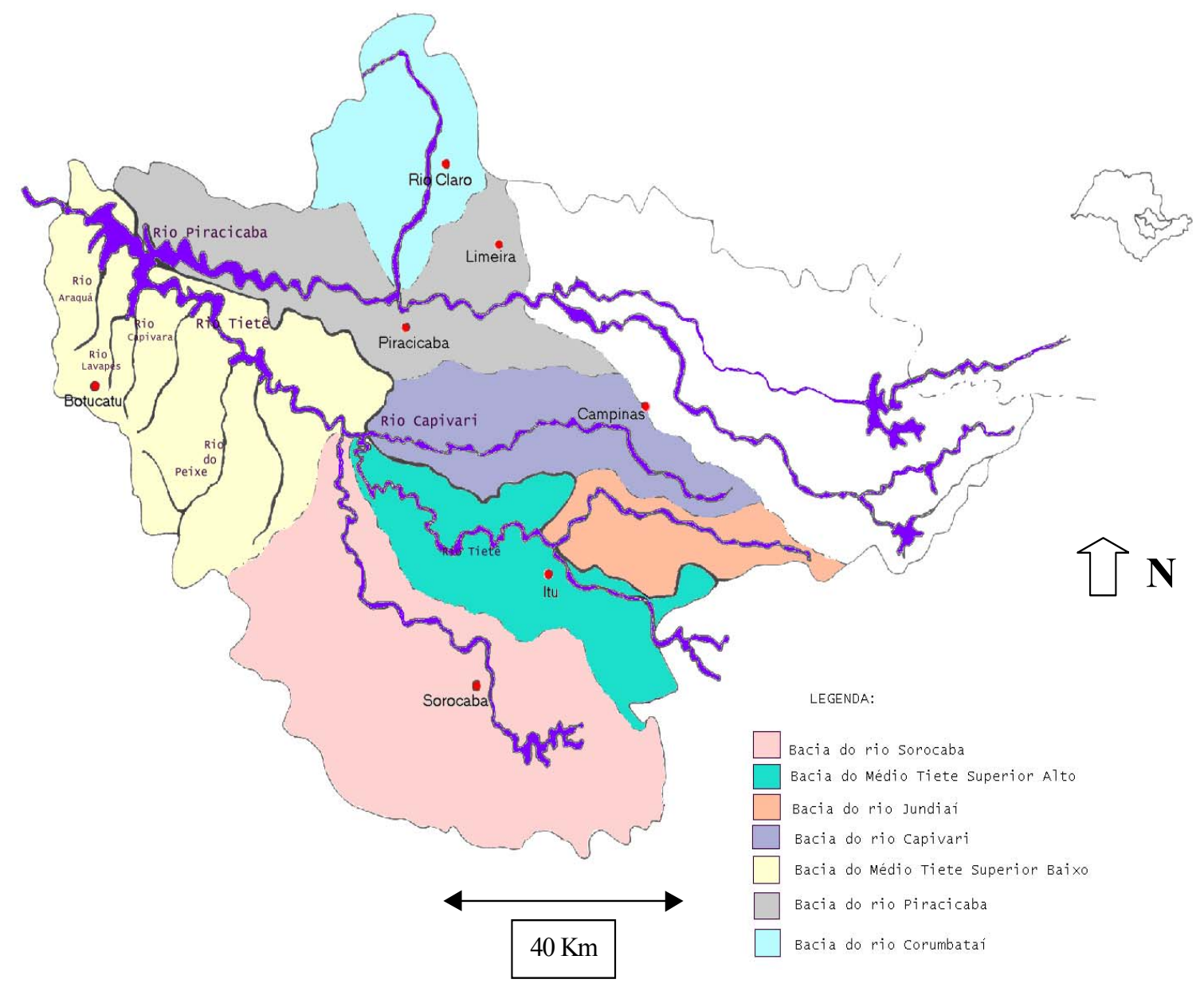

Figura 01: Bacia hidrográfica do Médio Tietê Superior (SP) e suas sub-bacias (Modificado de Sema, 1999 por Costa, 2001). 


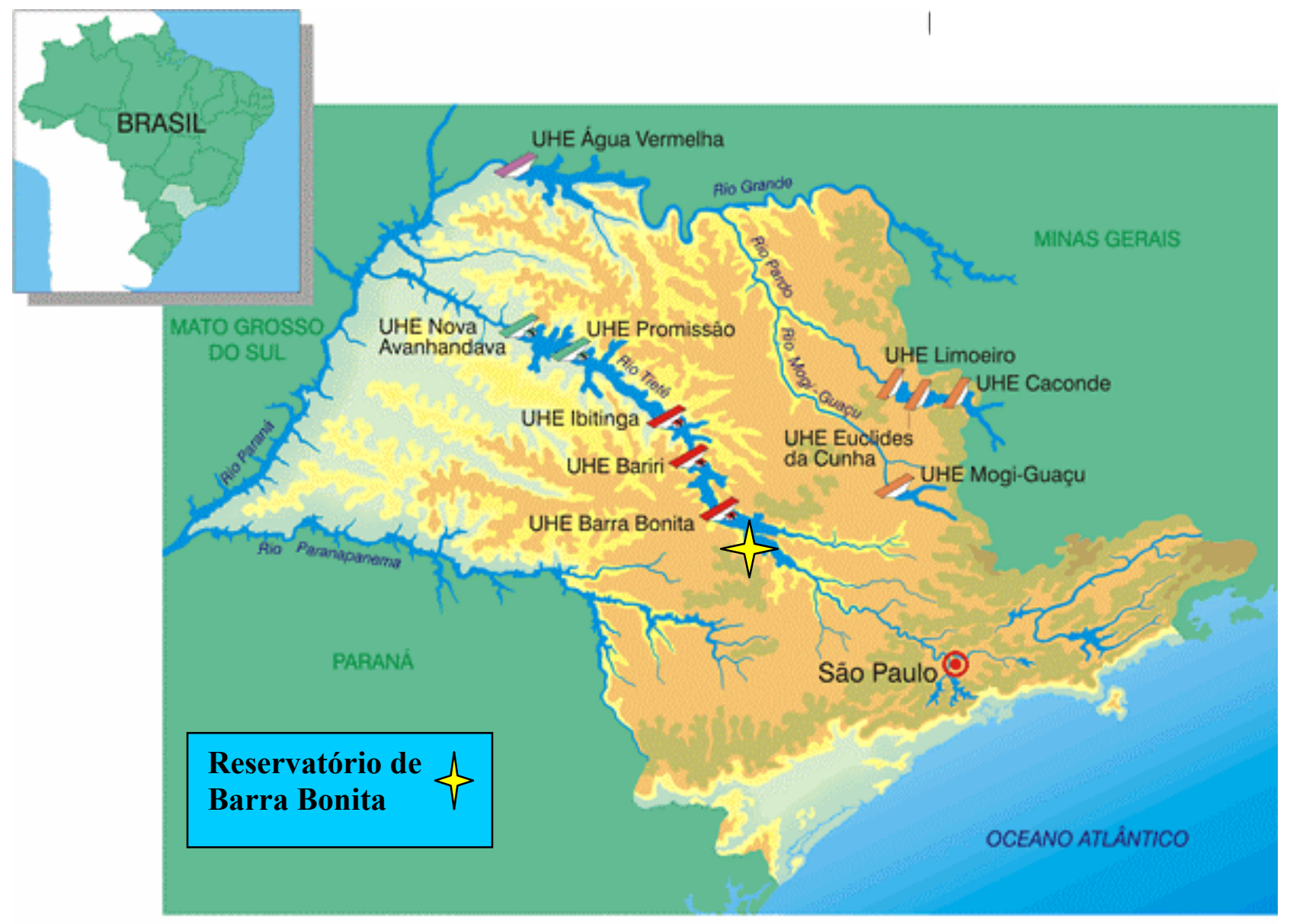

Figura 02: Mapa do Estado de São Paulo com a localização do reservatório de

Barra Bonita, no trecho do Médio Tietê Superior, SP. 


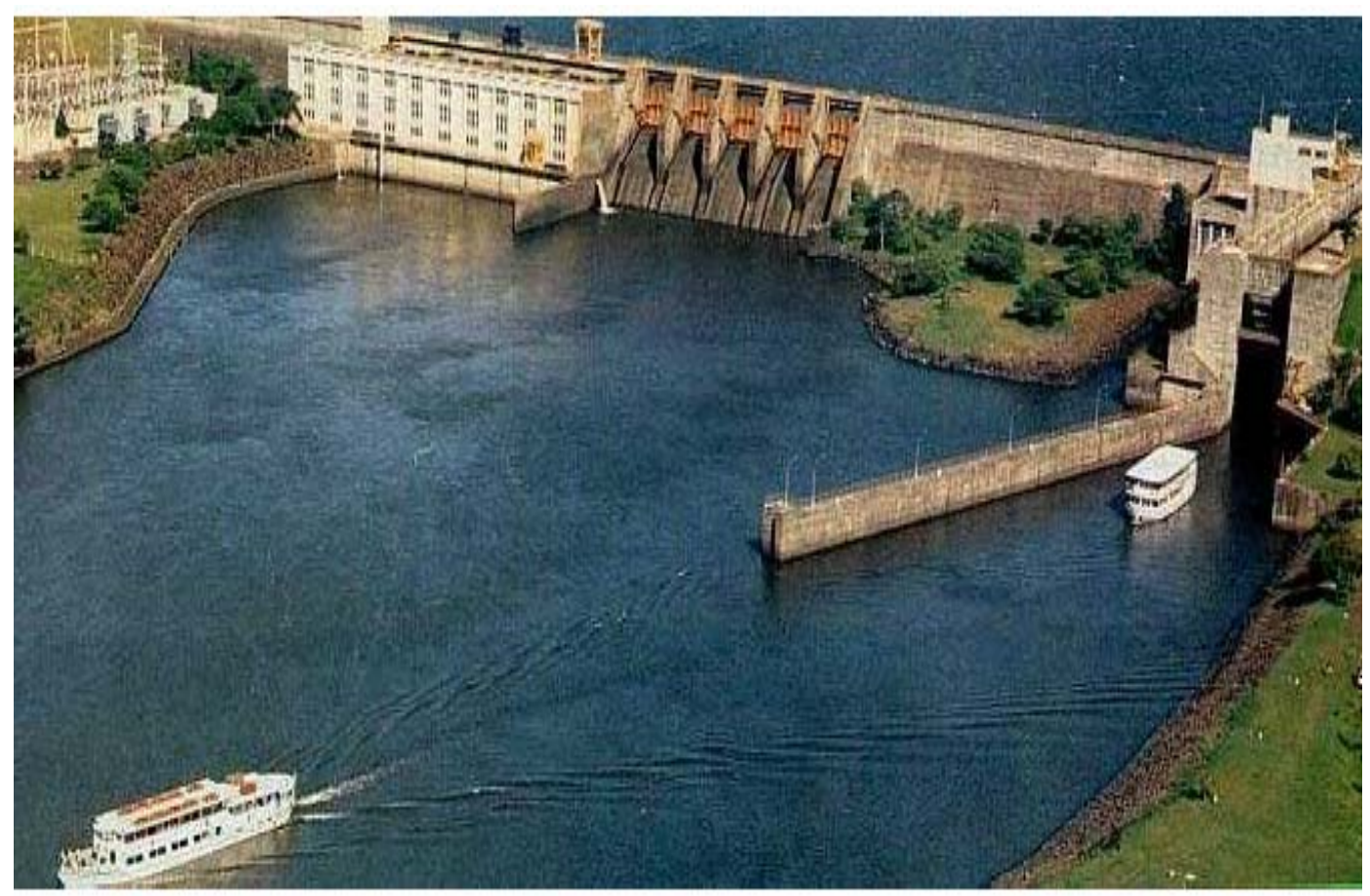

Figura 03: Rio Tietê, a jusante da barragem do Reservatório de Barra Bonita (Fonte: www.aestiete.com.br) 


\section{REFERÊNCIAS BIBLIOGRÁFICAS}

CALIJURI, M. C.(1988). Respostas fisio-ecológicas da comunidade fitoplantônica e fatores ecológicos em ecossistemas com diferentes estágios de eutrofização. São Carlos, Tese (Doutorado) EESC/USP, 293p.

CETESB- COMPANHIA DE TECNOLOGIA DE SANEAMENTO AMBIENTAL (1999). Relatório de qualidade de águas interiores do Estado de São Paulo,1998. $371 \mathrm{p}$.

COSTA, J. B. (2001). Avaliação ecotoxicológica da água e sedimento de tributários do reservatório de Barra Bonita (Médio Tietê Superior-SP). São Carlos (dissertação) mestrado EESC/USP, 281p.

ESPÍNDOLA, E. L. G. (1994). Dinâmica da associação congenérica das espécies de Notodiaptomus (Copepoda, Calanoida) no Reservatório de Barra Bonita- São Paulo. São carlos (tese) doutorado EESC/USP 363p.

HENRY, R; HINO, K; GENTIL, J. G; TUNDISI, J. G. (1993). Primary production and effects of enrichment with nitrate and phosphate on phytoplankton in the Barra Bonita reservoir (State of São Paulo, Brazil). Int. Ver. Ges. Hydrobiol.,v.70, n.4, p.561-573

MARQUISÁ, G. C. (1998). Sedimentação e fluxo vertical de nutrientes em dois reservatórios de distintos estados tróficos. Tese (doutorado) EESC-USP 150p.

MATSUMURA-TUNDISI, T. (1983). Tipologia de reservatórios do Estado de São Paulo: Ecologia do zooplâncton e do fitoplâncton. São Carlos, UFSCar.

OISHI, M. K. (1996). Caracterização do meio físico, das características físicas e químicas e de fluxo de nutrientes em tributários de sub-bacias hidrográficas da bacia hidrográfica do reservatório de Barra Bonita (Médio Tietê-SP). Tese (Doutorado) EESC-USP,211p. 
OLIVEIRA, H. T. (1993). Avaliação das condições limnológicas de um compartimento (Braço do Rio Capivara) e sua interação com o reservatório de Barra Bonita, SP., com ênfase na comunidade fitoplantônica. Tese (Doutorado), EESC/USP,328p.

PETRACCO, P. (1995). Determinação da biomassa e estoque de nitrogênio e fósforo de Polygonum spectabile Mart. e Paspalum repens Berg. da represa de Barra Bonita (SP). Dissertação (Mestrado). EESC- USP , 108p.

SANDES, M. A. L (1998). Estudos ecológicos em florescimento de Microcystis (cyanobactéria-Cyanophyceae) e interações com a flora bacteriana na represa de Barra Bonita- Médio Tietê/ SP. Tese (doutorado) EESC-USP 242p.

TUNDISI, J. G. (1981). Typology of reservoirs in Southern Brazil. Verh Internat. Limnol., v.21, p.1031-1039.

TUNDISI, J. G; MATSUMURA-TUNDISI, T.(1990). Limnology and eutrophication on Barra Bonita Reservoir, Sao Paulo State, Southern Brazil Arch. Hidrobiology, v.33, p.661-667,1990. 


\section{Capítulo 2}

\section{"Contaminação dos sedimentos por metais nos rios Tietê e Piracicaba, nos seus compartimentos de entrada no Reservatório de Barra Bonita- SP."}

\section{INTRODUÇÃO}

No Estado de São Paulo, as bacias hidrográficas estão expostas a diversos tipos de contaminantes de origem industrial, doméstico e agrícola, sendo necessário identificar e reconhecer os locais mais impactados, assim como os períodos de maior degradação ambiental (COSTA,2001)

A contaminação ambiental por agentes químicos tem ocorrido de forma intencional ou acidental, principalmente a partir de fontes não naturais e em decorrência da atividade humana. Lançamentos de poluentes metálicos provenientes de atividades industriais ou de mineração, principalmente, tem contribuído para o aumento dos níveis naturais de metais pesados em ambientes aquáticos. Estes são oriundos da extração de minérios, queima de combustíveis, processos industriais e utilização de fertilizantes (MOZETO, 2001).

De acordo com ESTEVES (1988), alguns metais como o magnésio, ferro, zinco manganês, cobalto, cobre e molibdênio são essenciais aos seres vivos (em pequenas 
concentrações) e tem importante papel no metabolismo dos organismos aquáticos. Outros como o mercúrio, chumbo, cádmio, prata, cromo, níquel e estanho não têm função biológica conhecida e são geralmente tóxicos a uma grande variedade de organismos.

Sabe-se que estes metais podem se acumular nos organismos, aí permanecendo por longo período de tempo. No meio aquático, estes acabam permanecendo no sedimento, associados a vários componentes, como argilas minerais e matéria orgânica, sendo que o organismo é um componente ativo no ecossistema aquático capaz de interferir ou alterar o equilíbrio químico existente no sistema.

Amostras de sedimentos podem indicar não apenas sua qualidade atual como também diferenças na sua composição ao longo do tempo (MASUTTI,1999). Num único testemunho (core) de sedimento, diferenças na concentração de um contaminante à diferentes profundidades refletem as alterações históricas no ecossistema devido ao acúmulo desses contaminantes (DIN,1992).

Este capítulo consiste na avaliação da presença e concentração de metais no sedimento e sua biodisponibilização, nas diferentes camadas de deposição sedimentar, fornecendo um diagnóstico da contaminação ambiental por metais, nos compartimentos iniciais do reservatório de Barra Bonita, a partir de 1960, década do início do funcionamento do reservatório.

\section{OBJETIVOS}

Neste estudo procurou-se avaliar a presença e concentração dos metais $\mathrm{Fe}, \mathrm{Mn}$, $\mathrm{Zn}, \mathrm{Cu}, \mathrm{Cd}, \mathrm{Cr}, \mathrm{Pb}$ e Ni, considerando a amostra total e a fração potencialmente biodisponível, em testemunhos de sedimentos, nos principais compartimentos iniciais do reservatório de Barra Bonita (rio Tietê e rio Piracicaba), bem como identificar os fatores intervenientes neste processo (químicos e físicos), e a influência do uso e ocupação dos solos da bacia, gerando informações complementares e necessárias para a avaliação da qualidade deste sistema dentro de uma perspectiva integrada (água/ sedimento). 


\section{METODOLOGIA}

\subsection{EM CAMPO:}

As coletas foram efetuadas em apenas um período, novembro de 2002, considerando que os aspectos analisados não sofrem influência significativa segundo variações do regime hídrico local.

As estações de coleta foram determinadas através de mapas topográficos, abrangendo áreas localizadas ao longo de cada tributário até a região do encontro de ambos. No Anexo 01 encontra-se a localização do Reservatório de Barra Bonita, seus principais tributários e os pontos de coleta e no Anexo 02 as coordenadas geográficas de cada estação de coleta.

As estações de coleta foram georreferenciadas com o uso do GPS Trimble Navigator, sendo estas coincidentes com estações já utilizadas em estudos anteriores e em andamento no Núcleo de Estudos de Ecossistemas Aquáticos (NEEA), do Centro de Recursos Hídricos e Ecologia Aplicada, da EESC/USP.

As amostras de sedimento foram coletadas com o auxílio do "Core Sampling", que possibilita a manutenção da deposição original das camadas sedimentares. Foram coletados dois testemunhos, sendo que o primeiro foi fracionado em sub-amostras de $10 \mathrm{~cm}$ e o segundo em sub-amostras de $5 \mathrm{~cm}$ (para a datação com ${ }^{210} \mathrm{~Pb}$ ) e acondicionadas em recipientes plásticos, conservadas em caixa térmica adequados ao transporte até o laboratório. 


\subsection{EM LABORATÓRIO:}

As amostras de sedimento foram expostas ao ambiente para evaporação da água e então permaneceram em estufa a $40^{\circ} \mathrm{C}$ (temperaturas mais elevadas podem modificar a concentração dos metais no sedimento) por 24 horas para secagem completa. Após estes procedimentos iniciais as amostras foram pulverizadas em almofariz e separadas para a realização das seguintes análises:

\section{- Granulometria}

Para a determinação da composição granulométrica de cada sub-amostra combinouse o método de peneiramento $(2,000 \mathrm{~mm}-0,062 \mathrm{~mm})$ e pipetagem (abaixo de 0,062 mm), de acordo com SUGUIO (1987). Este procedimento é indicado no caso de amostras constituídas por material fino, comum em reservatórios. Após a obtenção do percentual de cada diâmetro de partícula, efetuou-se a classificação granulométrica de acordo com a AGU (American Geophysical Union- Classificação de Wentworth).

\section{- Metais lábeis ou biodisponíveis}

Para a extração de metais potencialmente biodisponíveis adicionou-se $100 \mathrm{~mL}$ de $\mathrm{HCl}$ 0,1 M. As amostras foram submetidas a mesa agitadora por 2 horas, sendo o sobrenadante filtrado em membrana qualitativa e analisado por espectofotometria de absorção atômica por chama, de acordo com o método proposto por FIZMAN et al., (1984).

\section{- Metais Totais}

As amostras passaram por dissolução em ácido nítrico e perclórico de acordo com o método proposto por KRUG (1996) e a leitura realizada através do Espectro fotômetro de Absorção Atômica por Chama. 


\section{- Matéria Orgânica}

O percentual de matéria orgânica foi determinado através de calcineração das amostras de seidmento em mufla a $550^{\circ} \mathrm{C}$ por 2 horas, representando a perda por ignição ao calcular o peso da amostra antes e após o procedimento.

\section{- Geocronologia}

Após a determinação da umidade e da massa de sólidos de cada sub-amostra, foi determinado o rendimento do ${ }^{210} \mathrm{~Pb}$ atmosférico e ${ }^{226} \mathrm{Ra}$, de acordo com a metodologia proposta por CAZOTTI (2002).

\section{- Análise Estatística}

Considerando as correlações lineares que os dados trabalhados possuem (metais totais, metais potencialmente biodisponíveis, matéria orgânica e granulometria), foi aplicada uma análise de componentes principais.

Segundo MARCIANO (1999), a análise de componentes principais extrai combinações lineares do conjunto de dados, de maneira que elas sejam responsáveis pela maior proporção da variância dos dados de maneira decrescente (ou seja, o primeiro eixo é o que explica a maior parte da variância, o segundo, a segunda maior parte, etc) e é feita a partir de uma matriz de variância, covariância ou correlação, servindo para hierarquizar os indicadores que compunham a matriz de integridade.

\subsection{Levantamento de uso e ocupação dos solos}

Para correlacionar aspectos de uso e ocupação dos solos foram selecionadas cidades localizadas ao longo dos tributários de interesse (rio Piracicaba e rio Tietê), considerando a contribuição das mesmas através do transporte de poluentes pela água das chuvas e ventos e pelos efluentes gerados, tais como esgotos domésticos, industriais 
e agrícolas. Com esta finalidade, foram consultados levantamentos históricos realizados pelo IBGE através dos censos das décadas de 60, 70, 80, 90 e do ano 2000, abrangendo informações demograficas (número total de habitantes, englobando todas as faixas etárias), crescimento agrícola (área, em hectares, utilizada por propriedades agrícolas), industrialização (número de estabelecimentos industriais, considerando o total e especificando alguns gêneros de indústria). Na Tabela 02 são apresentados os municípios selecionados para cada tributário.

Tabela 02: Municípios selecionados para a pesquisa de uso e ocupação dos solos ao longo dos rios Piracicaba e Tietê

\begin{tabular}{|c|c|}
\hline \multicolumn{2}{|c|}{ Tributário } \\
\hline Rio Piracicaba & Rio Tietê \\
\hline Americana & Botucatu \\
\hline Limeira & Barueri \\
\hline Rio Claro & Jundiaí \\
\hline Piracicaba & Grande SP: Suzano \\
\hline & Grande SP: Osasco \\
\hline & Grande SP:Mogi das Cruzes \\
\hline
\end{tabular}

Os dados levantados através dos censos, para todos os municípios selecionados, são apresentados nos Anexos 03 A-03 F. 


\section{RESULTADOS E DISCUSSÕES}

4.1. Caracterização granulométrica e teor de matéria orgânica nos rios Tietê e Piracicaba no compartimento de entrada sedimentos do Reservatório de Barra Bonita.

\subsubsection{GRANULOMETRIA}

Os resultados da análise granulométrica obtidos no presente estudo são apresentados no Anexo 04. Observa-se que as amostras de sedimento apresentam predominância de partículas finas, já que o diâmetro máximo apresentado foi o correspondente a areia fina $(0,250 \mathrm{~mm}>\mathrm{d}>0,125 \mathrm{~mm})$. Na estação 7 (rio Tietê) verificouse a predominância da fração areia (fina), com 30\%, sendo que as demais amostras, de todas as estações, apresentaram composição granulométrica finíssima, com tendência pronunciada no sentido das frações mais finas (argilas).

RODGHER (2002), ao caracterizar os reservatórios em cascata do médio e baixo Tietê, também constatou as maiores frações de argila, tanto no período seco como chuvoso, nos rios Piracicaba e Tietê. COSTA (2001), verificou as maiores frações de argila nos sedimentos dos rios Piracicaba e Tietê. Segundo TONISSI (1999), a composição granulométrica pode apresentar variações entre os períodos seco e chuvoso. No período chuvoso, o material particulado fino é retirado do sedimento e ressuspenso, restando predominantemente areia. Acredita-se que somente as camadas iniciais do sedimento estejam diretamente expostas às variações do ambiente, preservando-se em maior grau as camadas de maior profundidade. $\mathrm{O}$ ambiente influencia na granulometria das partículas, uma vez que ambientes dinâmicos e com fluxo intenso, como rios, possuem sedimentos mais grosseiros. A medida que a velocidade das águas vai diminuindo, na área influenciada pelo represamento, a competência de agente transportador dos sedimentos diminui, ocorrendo maior acúmulo de sedimentos finos. 


\subsubsection{MATÉRIA ORGÂNICA}

Os resultados da análise de matéria orgânica são apresentados no Anexo 05. Observa-se que, com exceção das camadas $20 \mathrm{~cm}$ e $30 \mathrm{~cm}$ da estação 7 (rio Tietê) e 40 cm da estação 1 (rio Piracicaba), todas as amostras apresentaram valores maiores que $10 \%$, caracterizando sedimento orgânico. Verifica-se uma relação entre granulometria e teor de matéria orgânica, visto que as amostras de sedimento mineral (matéria orgânica menor que $10 \%$ ) apresentam sedimentos de maior granulometria. COSTA (2001) verificou padrão semelhante, com predominância das frações de areia nos sedimentos minerais.

A maioria das amostras apresentou valores considerados altos, acima de $15 \%$ de matéria orgânica. Isto representa, além do contingente produzido no próprio sistema, a entrada de dejetos provenientes de esgotos e indústrias da região e seus efeitos na produção orgânica do reservatório.

4.2. Caracterização dos sedimentos dos rios Tietê e Piracicaba no compartimento de entrada do Reservatório de Barra Bonita, com relação a concentração de metais totais e potencialmente biodisponíveis.

\subsubsection{METAIS TOTAIS}

Ferro- Na Figura 04 são apresentados os resultados das concentrações totais de ferro, nas diferentes camadas, em cada estação de coleta. Verifica-se um padrão heterogêneo de distribuição vertical. O menor valor encontrado foi de $170,0 \mathrm{mg} . \mathrm{kg}^{-1}$ (camada $20 \mathrm{~cm}$, estação 6- rio Tietê) e o máximo valor obtido foi de $16.724,0 \mathrm{mg} \cdot \mathrm{kg}^{-1}$ (camada 30cm, estação 1- rio Piracicaba). LEITE (2002) encontrou valores superiores em testemunhos de $40 \mathrm{~cm}$ de profundidade, no reservatório de Salto Grande, com valores entre 40.000,0 e 70.000,0 mg. $\mathrm{kg}^{-1}$. Verifica-se uma tendência ao decréscimo das concentrações de ferro no sentido longitudinal, ou seja, rio-represa nas estações localizadas no rio Piracicaba (estações 1, 2 e 3), com valores médios de 9.633,0, 5.692,0 
e 4.735,0 mg. $\mathrm{kg}^{-1}$, respectivamente. As estações localizadas no rio Tietê (estações 7, 6 e 5) apresentaram tendência ao acréscimo das concentrações no sentido rio-represa, com valores médios de 3.409,0, 9.335,0 e 10.487,0, $0 \mathrm{mg} . \mathrm{kg}^{-1}$ respectivamente.

De acordo com o sistema de classificação de THOMAS (1987), no qual a concentração de metais de ferro $<17.500,0 \mathrm{mg} \cdot \mathrm{Kg}^{-1}$ caracteriza sedimentos não poluídos, os sedimentos componentes dos principais compartimentos iniciais do reservatório de Barra Bonita são considerados não poluídos para este elemento. 

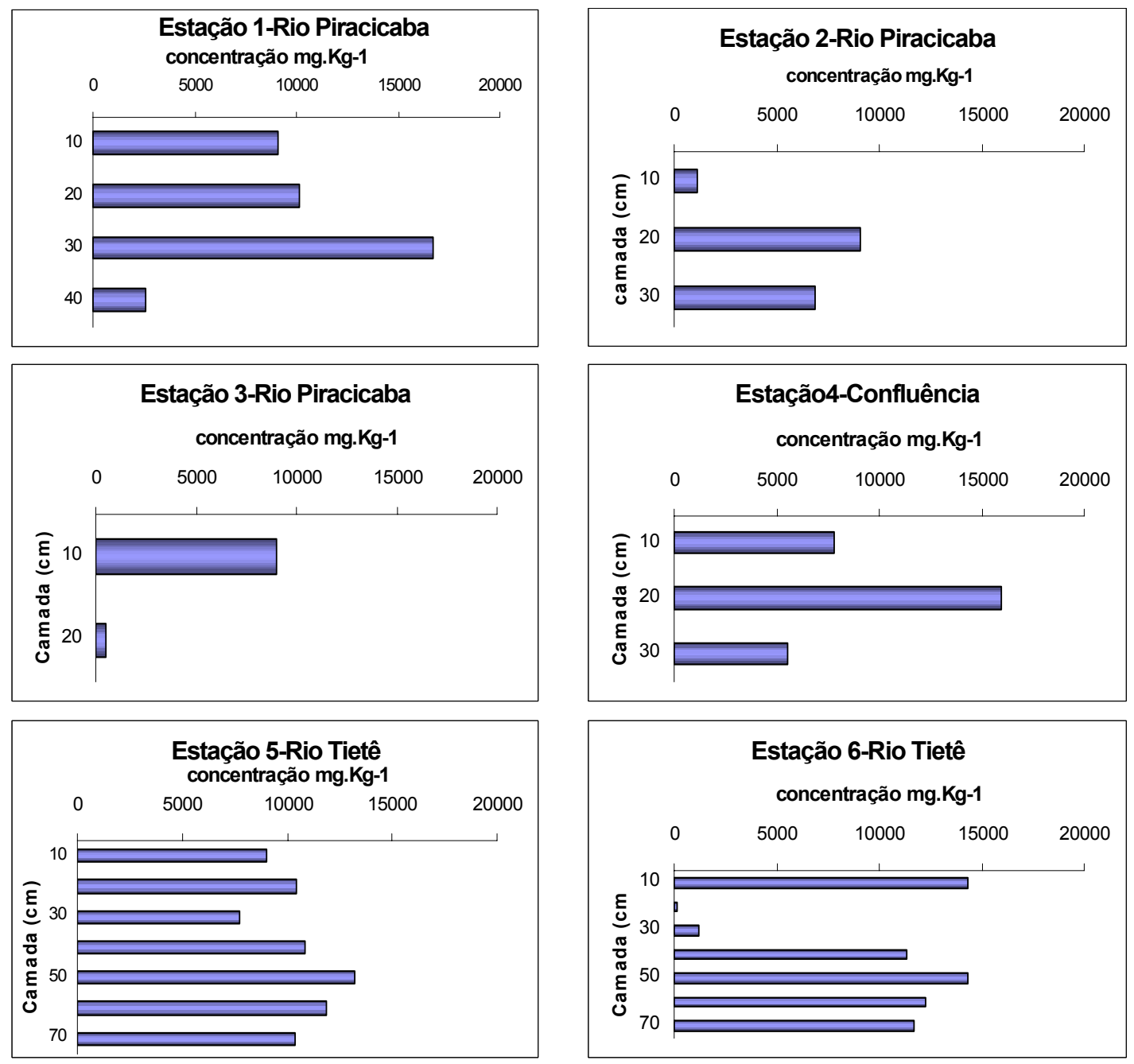

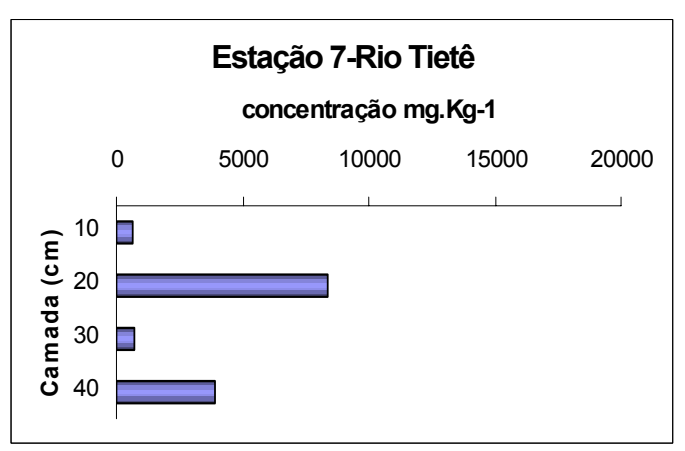

Figura 04: Concentração de Ferro total no perfil de sedimento, nas diferentes estações de coleta. 
Manganês- As concentrações totais de manganês ao longo do perfil de sedimento, em cada estação de coleta, são apresentadas na Figura 05. Verifica-se a inexistência de um padrão definido de distribuição nas camadas. Apenas as estações 2 e 3 demonstram um acréscimo gradual em relação aos sedimentos mais recentes. A camada de $20 \mathrm{~cm}$ da estação 6 apresentou valores inferiores aos detectáveis na análise, sendo que a maior concentração encontrada corresponde a mesma estação, na camada de $50 \mathrm{~cm}$ com $1.148,0 \mathrm{mg} \cdot \mathrm{kg}^{-1}$. ESPÍNDOLA et al. (1998), obteve o valor máximo de 550,0 mg.kg ${ }^{-1}$ de manganês, em sedimentos do reservatório de Salto Grande. Neste mesmo reservatório LEITE (2002), encontrou o valor máximo de 1.070,0 mg. $\mathrm{kg}^{-1}$. As estações localizadas no rio Piracicaba (estações 1, 2 e 3) não demonstram um padrão linear de crescimento no sentido rio-represa, com valores médios de 363,0, 455,0 e 250,0 mg. $\mathrm{kg}^{-1}$, respectivamente. No entanto, em uma análise similar das estações localizadas no rio Tietê (estações 7, 6 e 5), o padrão encontrado revela um acréscimo dos valores no mesmo sentido, com valores de 278,5; 733,8 e 697,7 mg.kg-1, respectivamente. A estação 4, região de confluência entre os rios Piracicaba e Tietê, apresentou valor médio de $632,3 \mathrm{mg} \cdot \mathrm{kg}^{-1}$.

Considerando-se os valores médios obtidos em cada estação, verifica-se que as estações 3 e 5 apresentam sedimentos não poluídos por manganês (concentração $<300$ mg. $\left.\mathrm{Kg}^{-1}\right)$, as estações 1 e 2 apresentam-se moderadamente poluídas (300,0 a 500,0 $\left.\mathrm{mg} \cdot \mathrm{Kg}^{-1}\right)$ e as estações 6 e 7 encontram-se altamente poluídas por manganês (concentração $>500,0 \mathrm{mg} \cdot \mathrm{Kg}^{-1}$ ), de acordo com a classificação proposta por THOMAS (1987). 

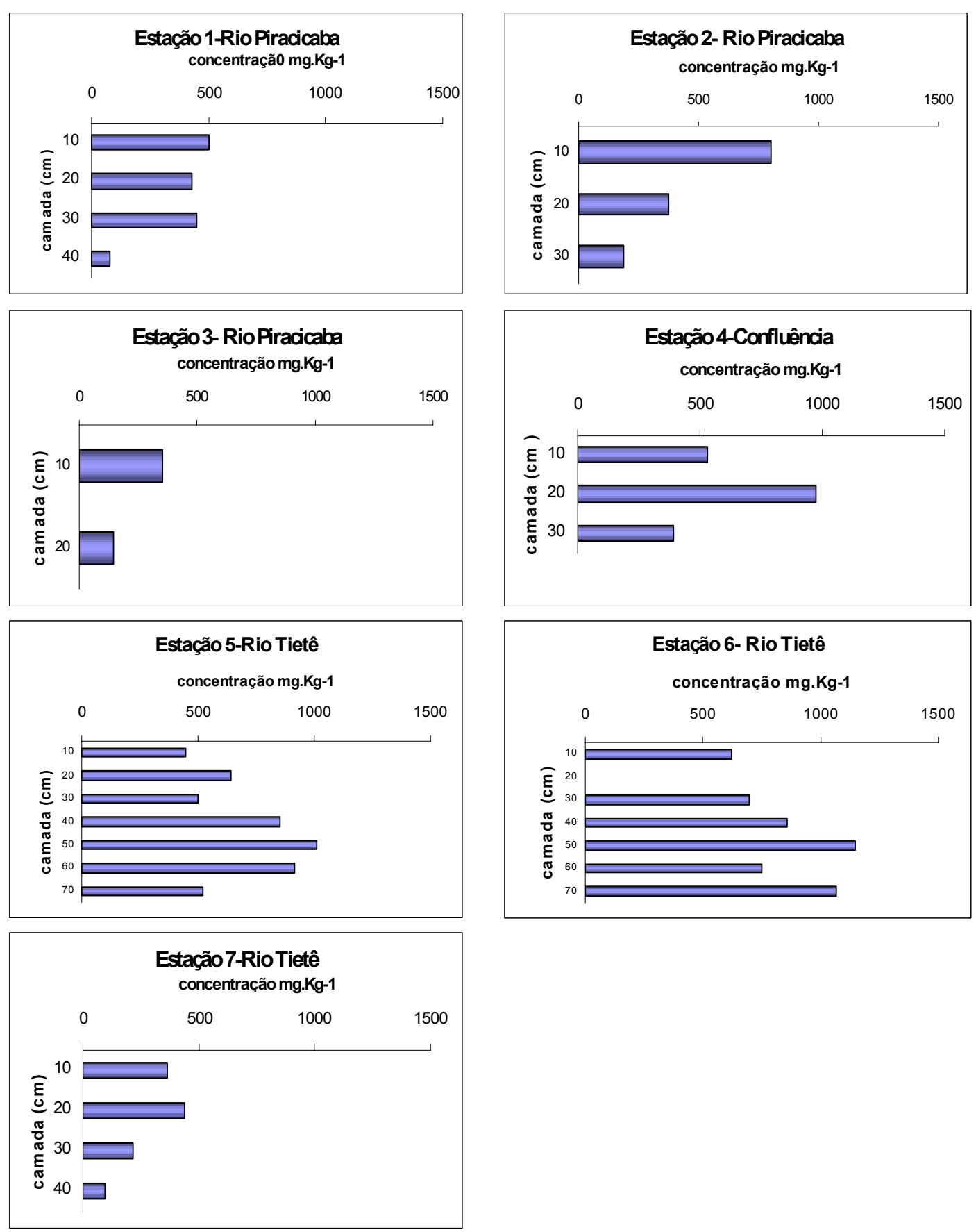

Figura 05: Concentração de Manganês total no perfil de sedimento, nas diferentes estações de coleta. 
Zinco- As concentrações totais de zinco estiveram abaixo dos limites de detecção (abaixo de $2 \mu \mathrm{g} / \mathrm{g}$ ), em todas as sub-amostras e estações de coleta.

Cobre- Na Figura 06 são apresentados os resultados das concentrações totais de cobre em cada sub-amostra, por estação de coleta. O valor mínimo encontrado permaneceu abaixo do limite de detecção da análise (abaixo de $1 \mu \mathrm{g} / \mathrm{g}$ ) na estação 5 (camada 30 ) $\mathrm{cm}$ e estação 6 (camada $20 \mathrm{~cm}$ ), ambas localizadas no rio Tietê. A maior concentração foi observada na estação 1 (rio Piracicaba), na camada de 30 cm, com 18,0 mg.kg-1.

LEITE (2002) encontrou valores médios superiores no reservatório de Salto Grande, entre 46,0 e 225,8 mg.kg-1 . ESPÍNDOLA et al.(1988), neste mesmo reservatório, encontrou valor máximo de $122,0 \mathrm{mg} \cdot \mathrm{kg}^{-1}$ e mínimo de $42,0 \mathrm{mg} \cdot \mathrm{kg}^{-1}$. Em trabalho realizado no Golfo do México, MACIAS-ZAMORA et al., (1999), encontrou valores inferiores, entre 14,0 e 18,0 mg. $\mathrm{kg}^{-1}$. Considerando-se as médias encontradas em cada estação de coleta, verifica-se que o rio Piracicaba apresenta maiores valores em relação ao rio Tietê, com uma tendência longitudinal de aumento de concentrações em sentido à represa. A maior média foi obtida na estação 4, que recebe cargas de ambos os tributários.

Ao analisar as concentrações médias e as concentrações totais de cobre nas camadas sedimentares (sub-amostras), verifica-se que os sedimentos dos principais compartimentos iniciais do reservatório de Barra Bonita não são considerados poluídos (concentração $<25,0$ mg. $\mathrm{Kg}^{-1}$ ), de acordo com a classificação de THOMAS (1987). 

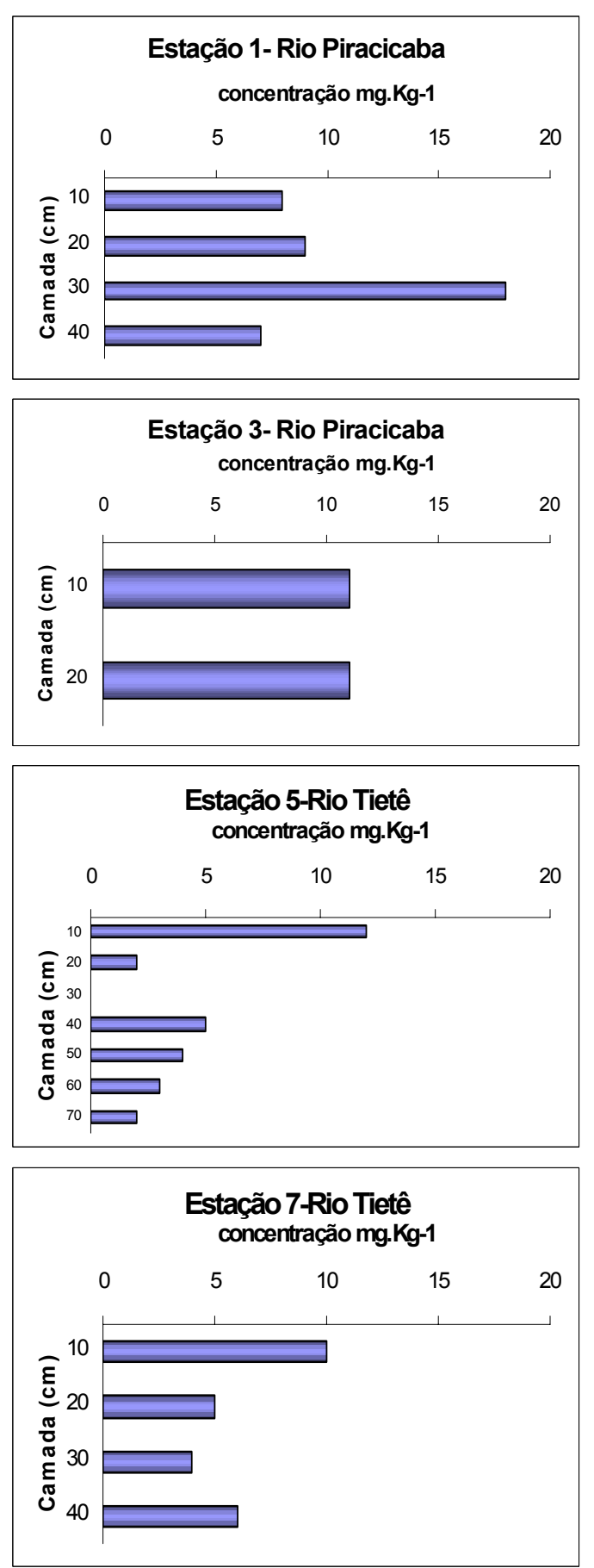
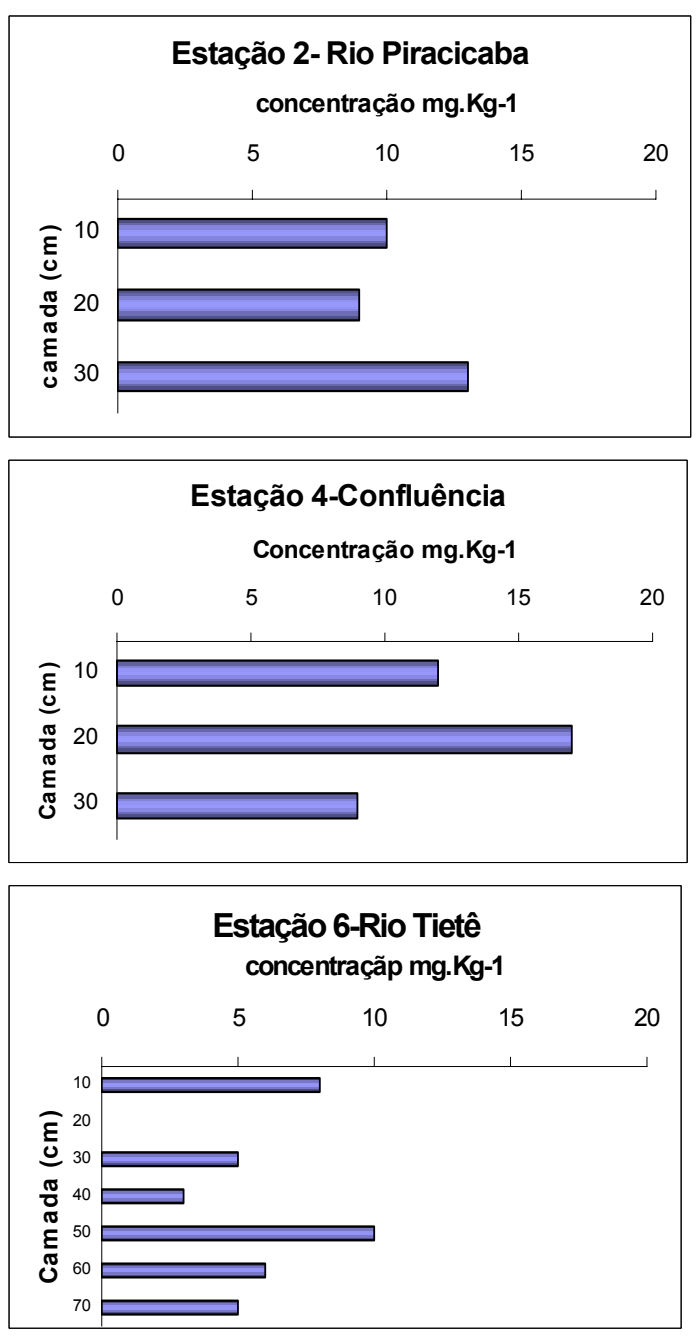

Figura 06: Concentração de Cobre total no perfil de sedimento, nas diferentes estações de coleta. 
Cádmio- Na Figura 07 são apresentadas as concentrações de cádmio total para cada camada sedimentar, nas diferentes estações de coleta. A menor concentração foi encontrada na estação 1 , na camada de $10 \mathrm{~cm}$, com $1,5 \mathrm{mg} \cdot \mathrm{kg}^{-1}$ (rio Piracicaba) e a maior concentração foi de 8,2 mg.kg-1, na camada de $40 \mathrm{~cm}$ da estação 7 (rio Tietê).

ESPÍNDOLA et al., (1998), obteve a máxima concentração de cádmio total de 1,24 mg. $\mathrm{kg}^{-1}$, em sedimentos do reservatório de Salto Grande. LEITE (2002), no mesmo reservatório, verificou concentração média máxima de 9,52mg. $\mathrm{kg}^{-1}$. MOORE \& RAMAMOORTHY (1984), estabeleceram concentrações de alguns metais em sedimentos de regiões naturais não impactadas e, de acordo com os autores, a concentração de cádmio destes ambientes é de $0,2 \mathrm{mg} \cdot \mathrm{kg}^{-1}$. Em relação a este valor, as concentrações médias de cádmio total nos sedimentos dos principais compartimentos iniciais do reservatório de Barra Bonita estão em torno de 20 a 30 vezes mais elevadas.

As maiores médias de concentração de cádmio total são verificadas nas estações localizadas no rio Tietê (estações 5, 6, 7 com 6,04; 6,55 e 7,37 mg.kg-1, respectivamente).

Considerando a classificação de THOMAS (1987), os sedimentos das estações localizadas no rio Tietê, em grande maioria, podem ser enquadrados como altamente poluídos (acima de 6,0 mg.kg- ${ }^{1}$ ).

NASCIMENTO \& MOZETO (2001) encontraram valores inferiores ao presente estudo em sedimentos próximos da nascente de tributários do rio Tietê, com 0,12 e 0,14 mg. $\mathrm{kg}^{-1}$, respectivamente. Com base nestes dados, é evidente o grau de contaminação ambiental decorrente do leito principal do rio Tietê 

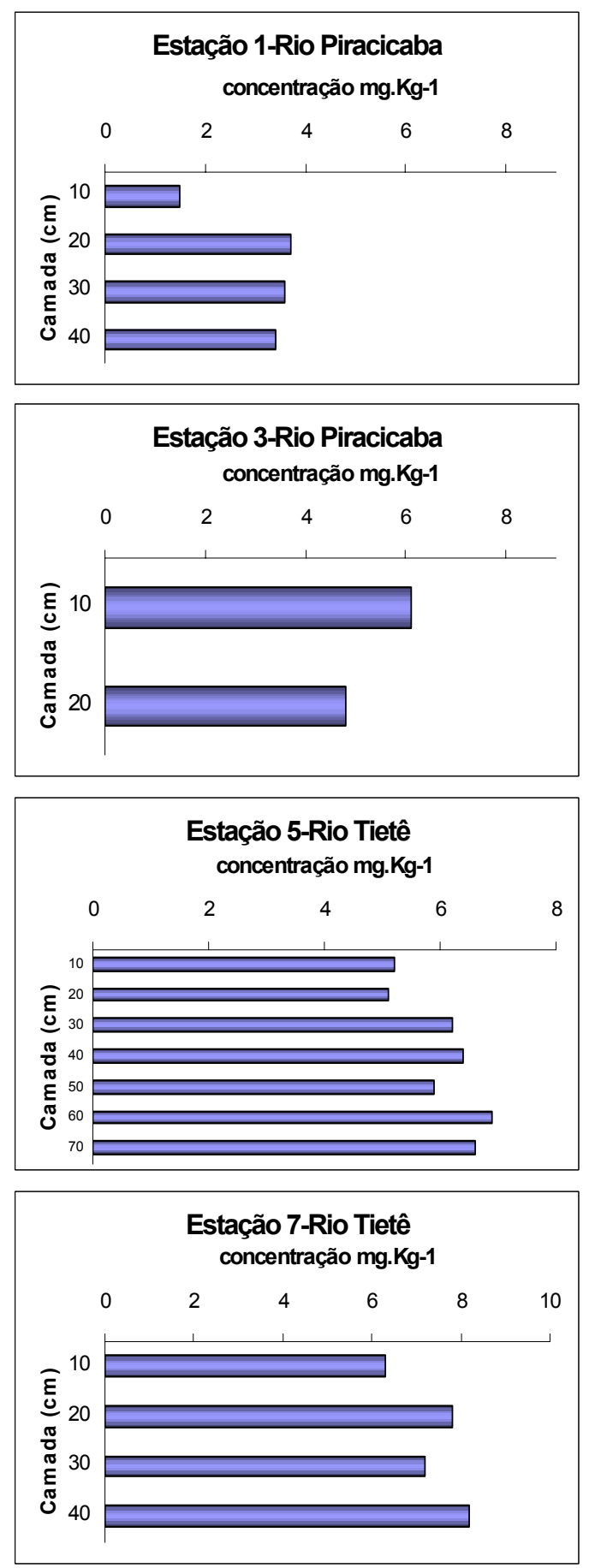
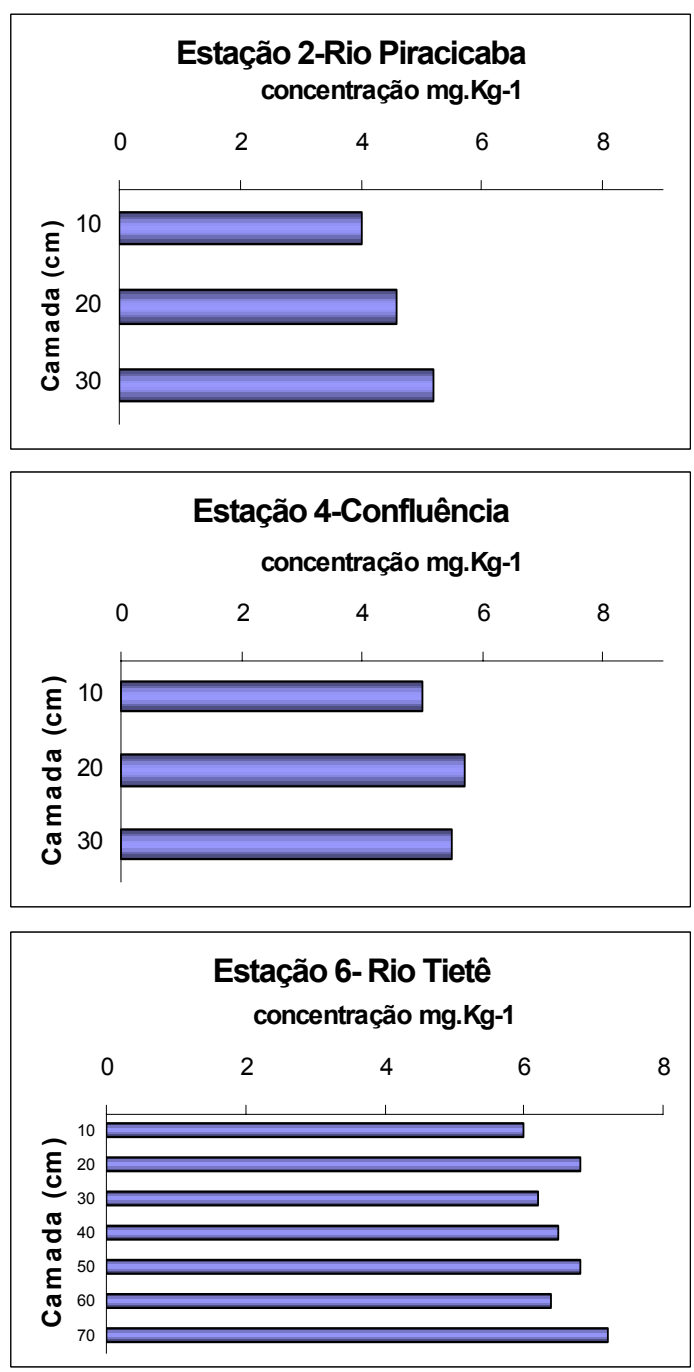

Figura 07: Concentração de Cádmio total no perfil de sedimento, nas diferentes estações de coleta.

Cromo- Todas as amostras apresentaram concentrações totais de cromo abaixo dos limites de quantificação do espectrofotômetro de absorção atômica (concentração menor que $1 \mu \mathrm{g} / \mathrm{g})$. 
Chumbo- Na Figura 08 são apresentadas as concentrações de chumbo total obtidas nas camadas sedimentares, por estação de coleta. Na estação 1 (rio Piracicaba) obteve-se as menores concentrações, sendo que das quatro sub-amostras obtidas no testemunho, três apresentaram valores abaixo da detecção pela análise. O maior valor encontrado foi de $288,0 \mathrm{mg} \cdot \mathrm{kg}^{-1}$, na estação 7 (rio Tietê), na camada de $10 \mathrm{~cm}$. Não se verifica nenhuma tendência longitudinal linear de distribuição de chumbo, sentido tributários-represa. A maior média registrada corresponde a estação 4 (região de confluência) com 203,7 mg. $\mathrm{kg}^{-1}$ de chumbo total, podendo ser classificada, segundo THOMAS (1987), como altamente poluída por este elemento $\left(>200 \mathrm{mg} \cdot \mathrm{kg}^{-1}\right)$. As estações $2,5,6$ e 7 são classificadas como moderadamente poluídas (entre 90 e $200 \mathrm{mg} \cdot \mathrm{kg}^{-1}$ ) e apenas a estação 1 apresenta-se não poluída (concentração< $<0$ mg.Kg-1).

MOORE \& RAMAMOORTHY (1984), estabeleceram valores entre 7,4 e 53,8 mg.Kg-1 de chumbo em sedimentos de regiões não impactadas. Verifica-se, desta forma, que os sedimentos dos principais compartimentos do reservatório de Barra Bonita apresentam valores de 5 a 6 vezes maiores.

Níquel- As concentrações de níquel total, obtidas nas diferentes camadas sedimentares por estação, são apresentadas na Figura 09. A distribuição de níquel total nas camadas é heterogênea, com a concentração mínima na camada $10 \mathrm{~cm}$, na Estação 1 (rio Piracicaba), apresentando valores inferiores ao detectáveis na análise e concentração máxima de $30,6 \mathrm{mg} \cdot \mathrm{kg}^{-1}$ na camada de 40 cm da estação 5 (rio Tietê). ESPÍNDOLA et al. (1998), encontrou valores entre 24,0 e 71,0 mg. $\mathrm{kg}^{-1}$ de níquel total em amostras de sedimento do reservatório de Salto Grande.

Verifica-se um padrão de aumento das concentrações longitudinalmente, sentido rio Piracicaba-represa, com as médias nas estações 1,2 e 3 de 5,8; 8,5 e 10,7 mg. $\mathrm{kg}^{-1}$, respectivamente. No caso do rio Tietê este padrão é inverso, com valores médios de 24,$9 ; 23,4$ e 21,7 mg. $\mathrm{kg}^{-1}$ nas estações 7, 6 e 5, respectivamente.

De acordo com a classificação proposta por THOMAS (1987) as estações localizadas no rio Piracicaba (1, 2 e 3), bem como a região de confluência, apresentam-se não poluídas por níquel (concentração<20 mg.kg-1), enquanto que as estações localizadas no rio Tietê $(5,6$ e 7) apresentam-se moderadamente poluídas (concentração entre 20 e 50 $\left.\mathrm{mg} \cdot \mathrm{kg}^{-1}\right)$. 

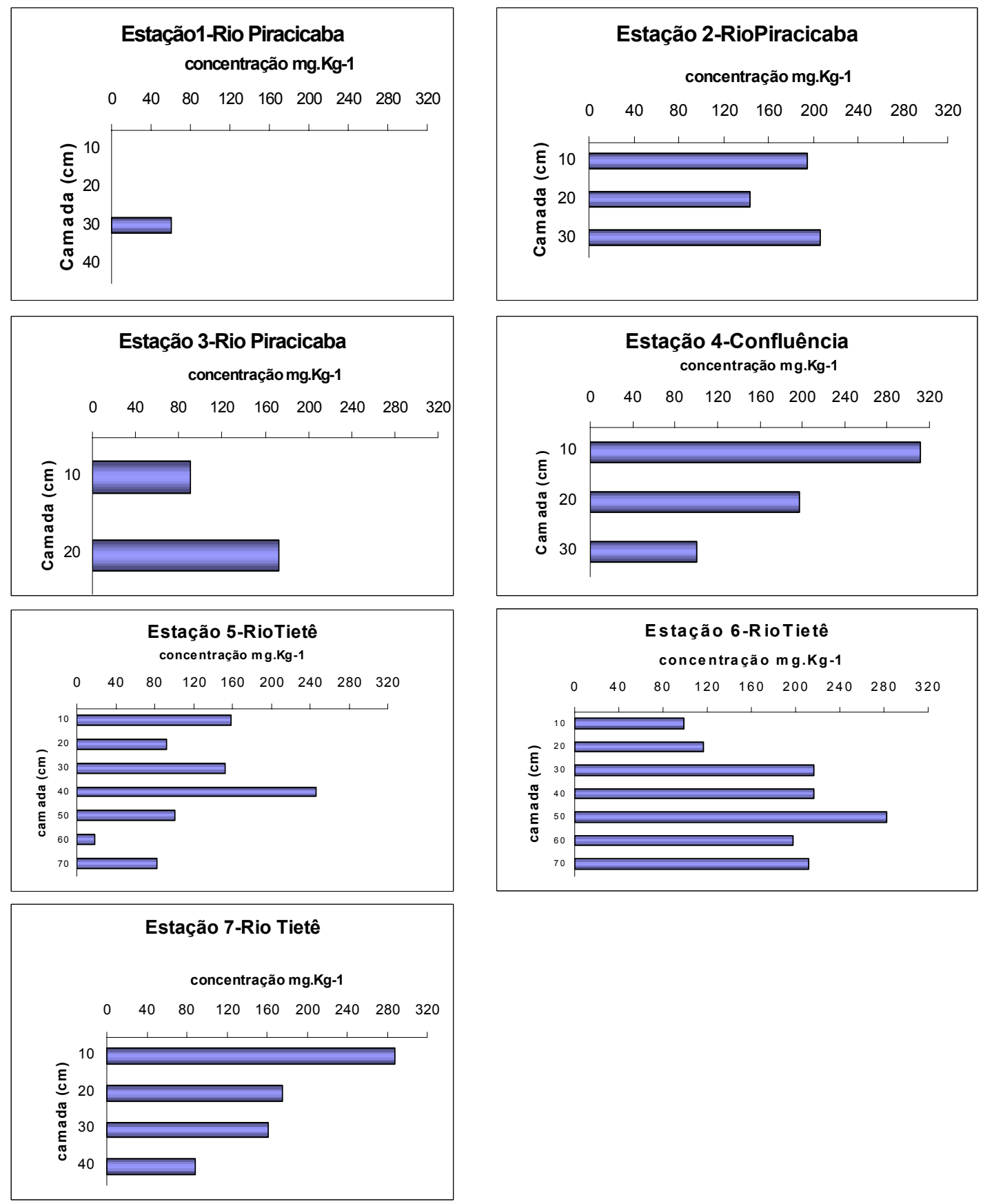

Figura 08: Concentração de chumbo total no perfil de sedimento, nas diferentes estações de coleta. 

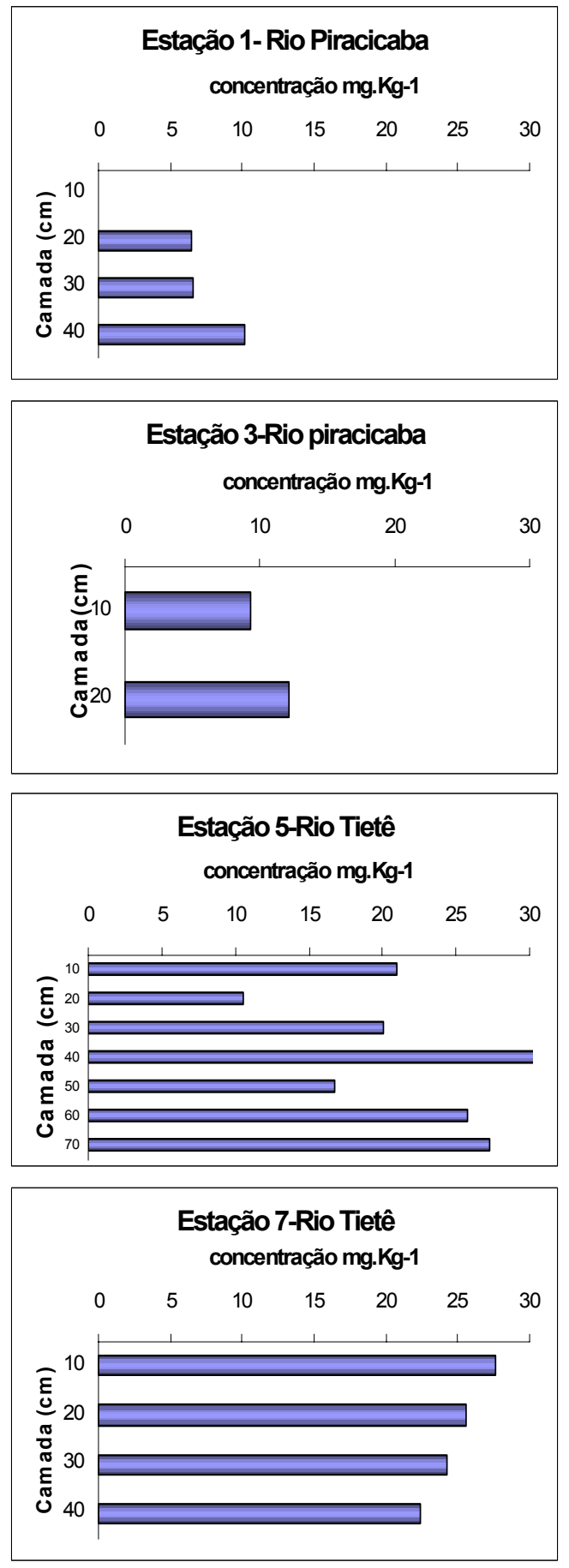
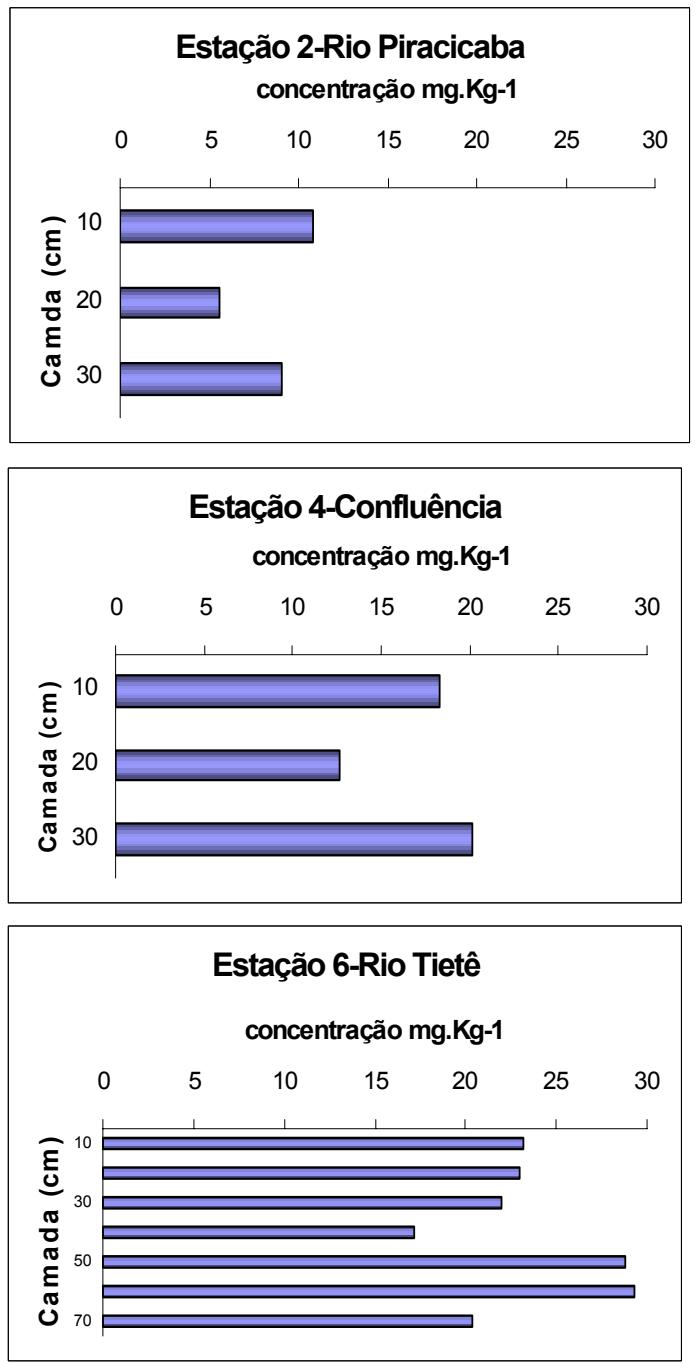

Figura 09: Concentração de níquel total no perfil de sedimento, nas diferentes estações de coleta. 


\subsubsection{METAIS POTENCIALMENTE BIODISPONÍVEIS}

A fração potencialmente biodisponível de metais, a partir do sedimento, foi obtida a partir da junção dos resultados das análises de metais totais e biodisponíveis, presentes em cada amostra. Desta forma, visualiza-se qual o percentual de metais da amostra total que poderá efetivamente se tornar biodisponível ao sistema. Cabe ressaltar que, nas amostras cujos valores da fração biodisponível do metal ultrapassaram a concentração total do elemento presente na amostra, optou-se por expressar o valor em $100 \%$ de biodisponibilidade.

Ferro- Na Figura 10 são apresentadas as concentrações de ferro potencialmente biodisponíveis. A maior concentração observada ocorreu na estação 7 (rio Tietê) com $14.682,0 \mathrm{mg} \cdot \mathrm{kg}^{-1}$, na camada de $20 \mathrm{~cm}$ e a menor na camada de $40 \mathrm{~cm}$ da mesma estação, com 487,0 mg.kg ${ }^{-1}$. COSTA (2001), analisando os sedimentos do reservatório de Barra Bonita, encontrou valores mais baixos, variando de 48,6 e 52,5 mg. $\mathrm{kg}^{-1}$ As concentrações médias obtidas estão entre 909,5 e 12.777,0 mg. $\mathrm{kg}^{-1}$, LEITE (2002) encontrou valores médios entre 4.910,0 e 7.275,0mg. $\mathrm{kg}^{-1}$ de ferro biodisponível em sedimentos do reservatório de Salto Grande.

No entanto, outros reservatórios do Estado de São Paulo, como Bariri e Ibitinga, apresentaram valores bem superiores $(27.866,0$ mg.kg-1 e $17.135,0$ mg.kg-1 respectivamente), segundo resultados obtidos por ESTEVES (1981).

Na Tabela 03 são apresentados os percentuais de ferro potencialmente biodisponível, a partir dos sedimentos, em cada sub-amostra.

Os percentuais biodisponíveis de ferro são extremamente elevados, com $73 \%$ das amostras apresentando $100 \%$ de biodisponibilidade. LEITE (2002), obteve a máxima fração de ferro biodisponível na ordem de $12 \%$. TONISSI (1999) encontrou valores entre 0,09 e $2,95 \%$. 

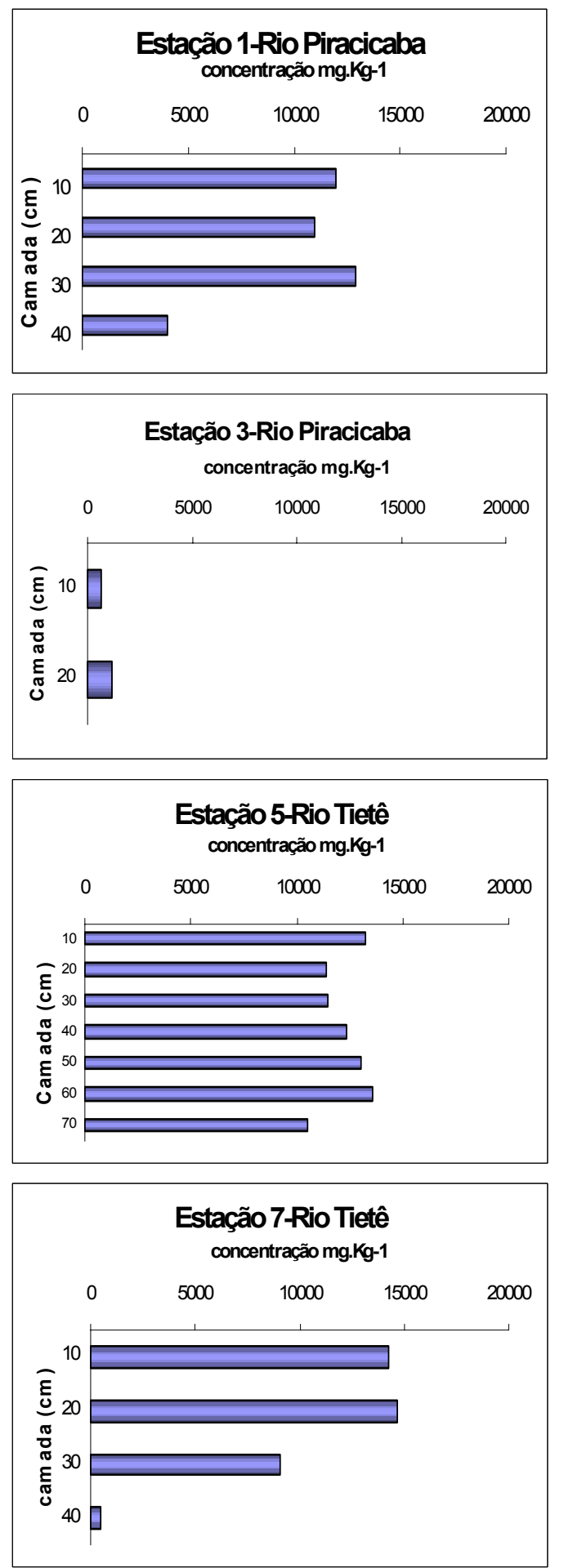
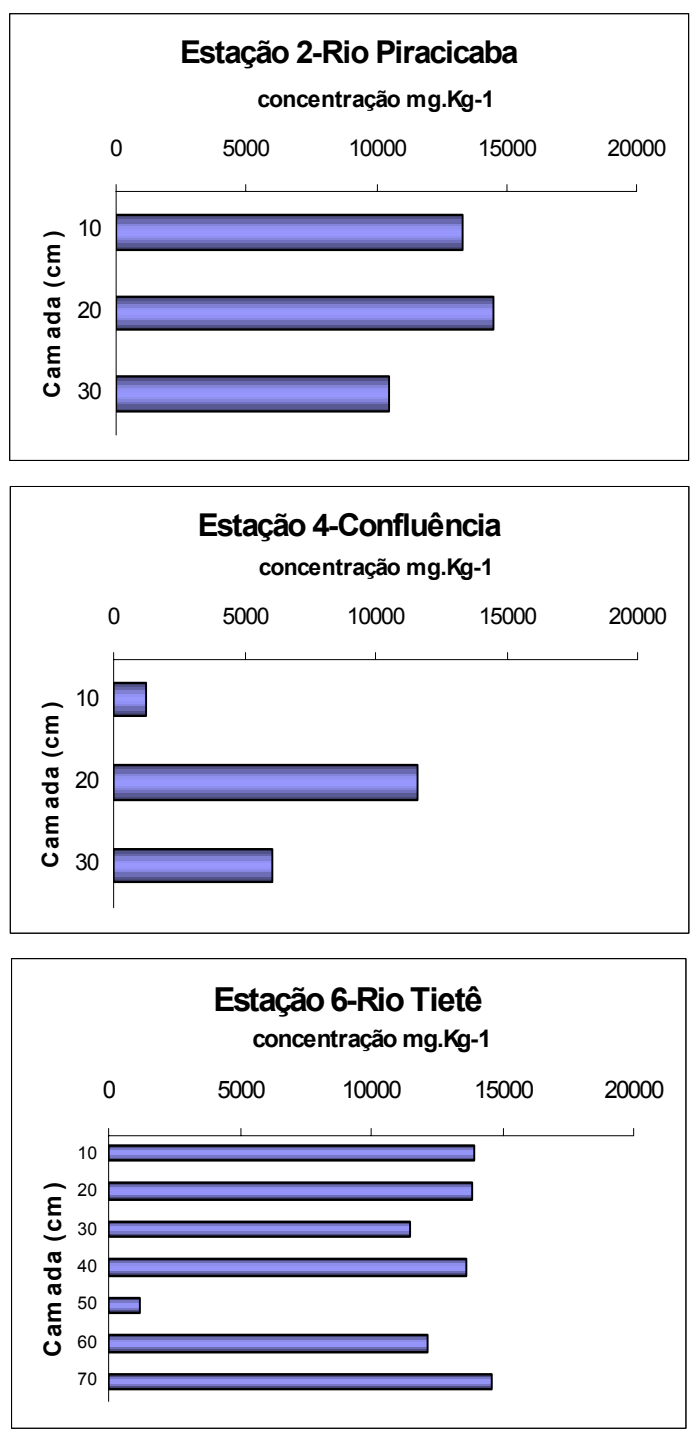

Figura 10: Concentração de ferro potencialmente biodisponível no perfil de sedimento, nas diferentes estações de coleta 
Tabela 03: Relação entre as concentrações de ferro total e potencialmente biodisponível obtidas em amostras de sedimento do compartimento de entrada Reservatório de Barra Bonita

\begin{tabular}{|c|c|c|c|c|}
\hline Estação & Camada (cm) & $\begin{array}{c}\text { Fe Total } \\
\left(\mathrm{mg.kg}^{-1}\right)\end{array}$ & $\begin{array}{c}\text { Fe } \\
\text { Biod.(mg.kg } \\
\end{array}$ & $\%$ biod \\
\hline \multirow[t]{4}{*}{1} & 10 & 9.075 & 12.000 & 100,0 \\
\hline & 20 & 10.171 & 10.948 & 100,0 \\
\hline & 30 & 16.724 & 12.878 & 77,0 \\
\hline & 40 & 2.563 & 3.994 & 100,0 \\
\hline \multirow[t]{3}{*}{2} & 10 & 1.137 & 13.324 & 100,0 \\
\hline & 20 & 9.056 & 14.524 & 100,0 \\
\hline & 30 & 6.885 & 10.482 & 100,0 \\
\hline \multirow[t]{2}{*}{3} & 10 & 9.042 & 626 & 6,9 \\
\hline & 20 & 470 & 1.193 & 100,0 \\
\hline \multirow[t]{3}{*}{4} & 10 & 7.794 & 1.208 & 15,0 \\
\hline & 20 & 15.943 & 11.626 & 72,9 \\
\hline & 30 & 5.544 & 6.058 & 100,0 \\
\hline \multirow[t]{7}{*}{5} & 10 & 8.984 & 13.266 & 100,0 \\
\hline & 20 & 10.439 & 11.396 & 100,0 \\
\hline & 30 & 7.703 & 11.442 & 100,0 \\
\hline & 40 & 10.819 & 12.324 & 100,0 \\
\hline & 50 & 13.216 & 13.054 & 98,7 \\
\hline & 60 & 11.893 & 13.566 & 100,0 \\
\hline & 70 & 10.353 & 10.486 & 100,0 \\
\hline \multirow[t]{7}{*}{6} & 10 & 14.324 & 13.916 & 97,2 \\
\hline & 20 & 170 & 13.868 & 100,0 \\
\hline & 30 & 1.199 & 11.454 & 100,0 \\
\hline & 40 & 11.331 & 13.598 & 100,0 \\
\hline & 50 & 14.339 & 1.159 & 8,1 \\
\hline & 60 & 12.247 & 12.118 & 98,9 \\
\hline & 70 & 11.735 & 14.612 & 100,0 \\
\hline \multirow[t]{4}{*}{7} & 10 & 666 & 14.232 & 100,0 \\
\hline & 20 & 8.363 & 14.682 & 100,0 \\
\hline & 30 & 692 & 9.034 & 100,0 \\
\hline & 40 & 3.918 & 487 & 1,2 \\
\hline
\end{tabular}


Manganês- Na Figura 11 são apresentadas as concentrações de manganês potencialmente biodisponíveis, verificando-se a maior concentração na camada de 70 $\mathrm{cm}$, na estação 6 (rio Tietê) com 1.055,4 mg. $\mathrm{kg}^{-1}$. A menor concentração foi obtida na camada de $40 \mathrm{~cm}$ da estação 7, com 87,8 mg. $\mathrm{kg}^{-1}$. LEITE (2002), analisando os metais potencialmente biodisponíveis no Reservatório de Salto Grande, verificou as maiores concentrações deste elemento nas camadas mais recentes do testemunho, com valores entre 400,0 e 600,0 mg. $\mathrm{kg}^{-1}$. COSTA (2001), estudando o Reservatório de Barra Bonita e seus tributários encontrou valores inferiores ao do presente estudo com concentrações médias entre 9,34 e 13,6 mg.kg-1 .

Na Tabela 04 são apresentados os percentuais de manganês potencialmente biodisponível, a partir dos sedimentos, em cada sub-amostra. Observam-se altos percentuais de manganês potencialmente biodisponível a partir dos sedimentos, podendo-se considera-lo de alta mobilidade ao longo do perfil. Todos os valores encontrados situam-se acima de $40 \%$. 

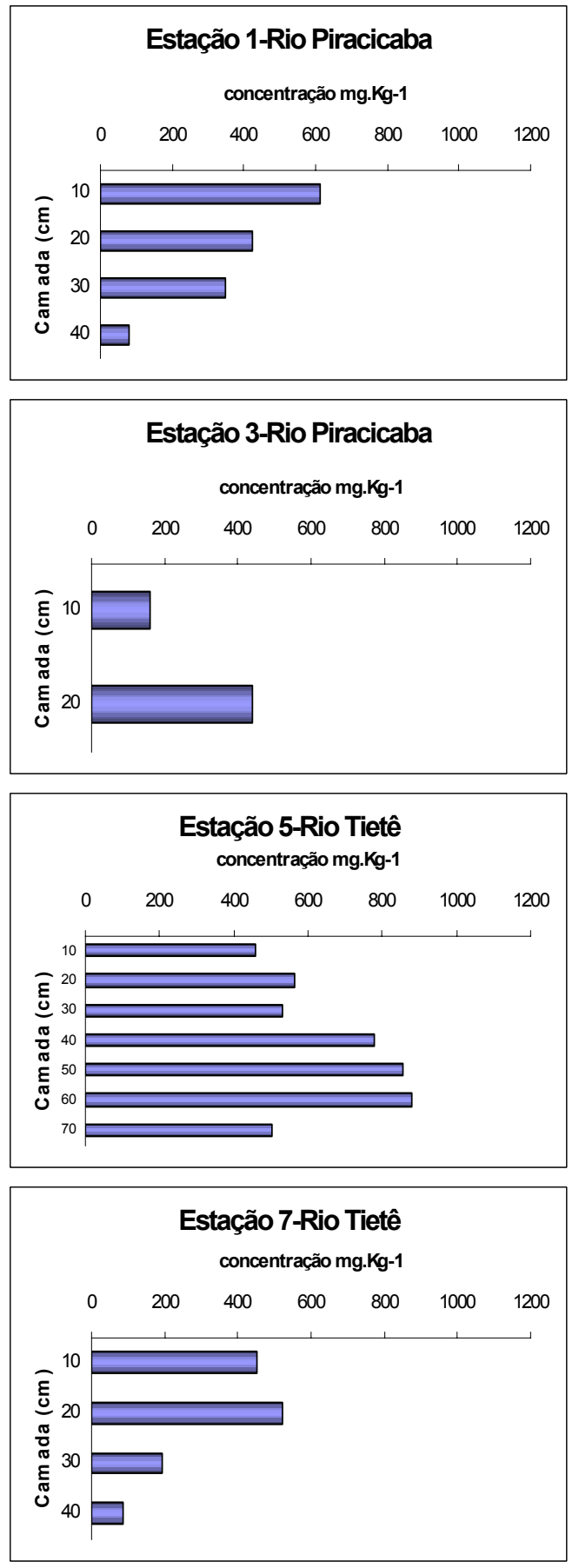
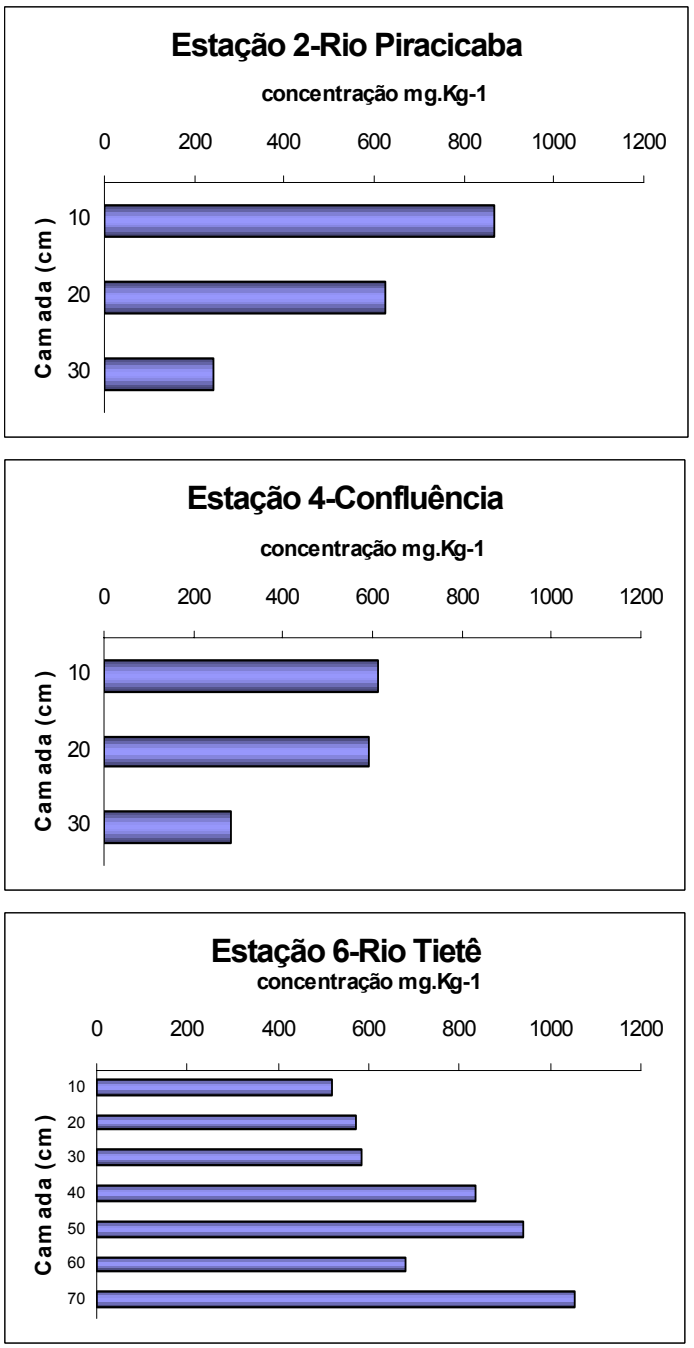

Figura 11: Concentração de manganês potencialmente biodisponível no perfil de sedimento, nas diferentes estações de coleta. 
Tabela 04: Relação entre as concentrações de manganês total e potencialmente biodisponível obtidas em amostras de sedimento do compartimento de entrada do Reservatório de Barra Bonita

\begin{tabular}{|c|c|c|c|c|}
\hline Estação & Camada $(\mathrm{cm})$ & $\begin{array}{c}\text { Mn Total } \\
\left(\mathrm{mg}^{\prime} \mathrm{kg}^{-1}\right)\end{array}$ & $\begin{array}{l}\text { Mn Biod. } \\
\left(\mathrm{mg}^{\prime} \mathrm{kg}^{-1}\right)\end{array}$ & $\%$ Biod \\
\hline \multirow[t]{4}{*}{1} & 10 & 500 & 613 & 100,0 \\
\hline & 20 & 428 & 425.4 & 99,4 \\
\hline & 30 & 448 & 348.8 & 77,9 \\
\hline & 40 & 76 & 80.4 & 100,0 \\
\hline \multirow[t]{3}{*}{2} & 10 & 804 & 869 & 100,0 \\
\hline & 20 & 377 & 624.2 & 100,0 \\
\hline & 30 & 185 & 242.6 & 100,0 \\
\hline \multirow[t]{2}{*}{3} & 10 & 355 & 160.6 & 45,2 \\
\hline & 20 & 145 & 438.8 & 100,0 \\
\hline \multirow[t]{3}{*}{4} & 10 & 531 & 612 & 100,0 \\
\hline & 20 & 974 & 593.4 & 60,9 \\
\hline & 30 & 392 & 281.6 & 71,8 \\
\hline \multirow[t]{7}{*}{5} & 10 & 446 & 460 & 100,0 \\
\hline & 20 & 642 & 562 & 87,5 \\
\hline & 30 & 498 & 533 & 100,0 \\
\hline & 40 & 851 & 776.4 & 91,2 \\
\hline & 50 & 1011 & 856 & 84,6 \\
\hline & 60 & 914 & 880.6 & 96,3 \\
\hline & 70 & 522 & 503 & 96,3 \\
\hline \multirow[t]{7}{*}{6} & 10 & 621 & 518.8 & 83,5 \\
\hline & 20 & 0 & 571 & 100,0 \\
\hline & 30 & 696 & 583 & 83,8 \\
\hline & 40 & 856 & 834.8 & 97,5 \\
\hline & 50 & 1148 & 939 & 81,8 \\
\hline & 60 & 749 & 680 & 90,8 \\
\hline & 70 & 1067 & 1055.4 & 98,9 \\
\hline \multirow[t]{4}{*}{7} & 10 & 363 & 450.2 & 100,0 \\
\hline & 20 & 437 & 521.6 & 100,0 \\
\hline & 30 & 218 & 195.2 & 89,5 \\
\hline & 40 & 96 & 87.8 & 91,4 \\
\hline
\end{tabular}


Zinco- Na Figura 12 são apresentados os resultados das concentrações de zinco potencialmente biodisponíveis. A maior concentração de zinco ocorreu na estação 7 (rio Tietê), na camada $20 \mathrm{~cm}$, com $42,6 \mathrm{mg} \cdot \mathrm{kg}^{-1}$. A menor concentração foi verificada na camada $40 \mathrm{~cm}$ da mesma estação, com 7,81 mg.kg-1 . SILVÉRIO (1999), encontrou concentrações variando entre 21,0 e $33,0 \mathrm{mg} \cdot \mathrm{kg}^{-1}$, nos sedimentos do reservatório de Barra Bonita. DORNFELD (2002), encontrou valores inferiores nos sedimentos dos tributários da represa do Lobo, com a máxima concentração de $0,54 \mathrm{mg} \cdot \mathrm{kg}^{-1}$ de zinco biodisponível. Deve-se considerar que este estudo abrange somente o compartimento inicial do reservatório de Barra Bonita, uma região que sofre mais diretamente os efeitos do represamento, caracterizando um ambiente lêntico para a maioria das estações analisadas. Isso favorece a deposição e armazenamento de contaminantes nos sedimentos, ao considerar que o fluxo d'água se torna tridimensional nestes casos.

As concentrações de zinco biodisponível foram extremamente altas em relação as concentrações totais deste elemento (que apresentaram valores abaixo do limite de detecção pela análise), podendo-se considerar que todo o zinco presente nos sedimentos $(100 \%)$ dos principais compartimentos iniciais do reservatório de Barra Bonita é potencialmente biodisponível ao sistema.

Cobre- Na Figura 13 são apresentados os resultados das concentrações de cobre potencialmente biodisponível. A maior concentração de cobre foi observada na estação 6 (rio Tietê) com 40,9 mg. $\mathrm{kg}^{-1}$, na camada de $10 \mathrm{~cm}$, e a menor na estação 7 (rio Tietê), com 9,2 mg. $\mathrm{kg}^{-1}$ na camada de $40 \mathrm{~cm}$. TONISSI (1999), encontrou a concentração máxima de $146,5 \mathrm{mg} . \mathrm{kg}^{-1}$ de cobre potencialmente biodisponível nos sedimentos do reservatório de Salto Grande- SP; LEITE (2002), neste mesmo reservatório, obteve valor máximo de $141,38 \mathrm{mg} \cdot \mathrm{kg}^{-1}$. DORNFELD (2002), obteve o valor máximo de 10,2 mg. $\mathrm{kg}^{-1}$ de cobre potencialmente biodisponível nos sedimentos da represa do Lobo, próximo à barragem.

Os valores de cobre biodisponível excederam os valores de cobre total em todas as sub-amostras. Desta forma considera-se a presença deste elemento na forma $100 \%$ mobilizada. O cobre é considerado um dos metais mais tóxicos, principalmente para a ictiofauna, causando, muitas vezes, morte por asfixia. 

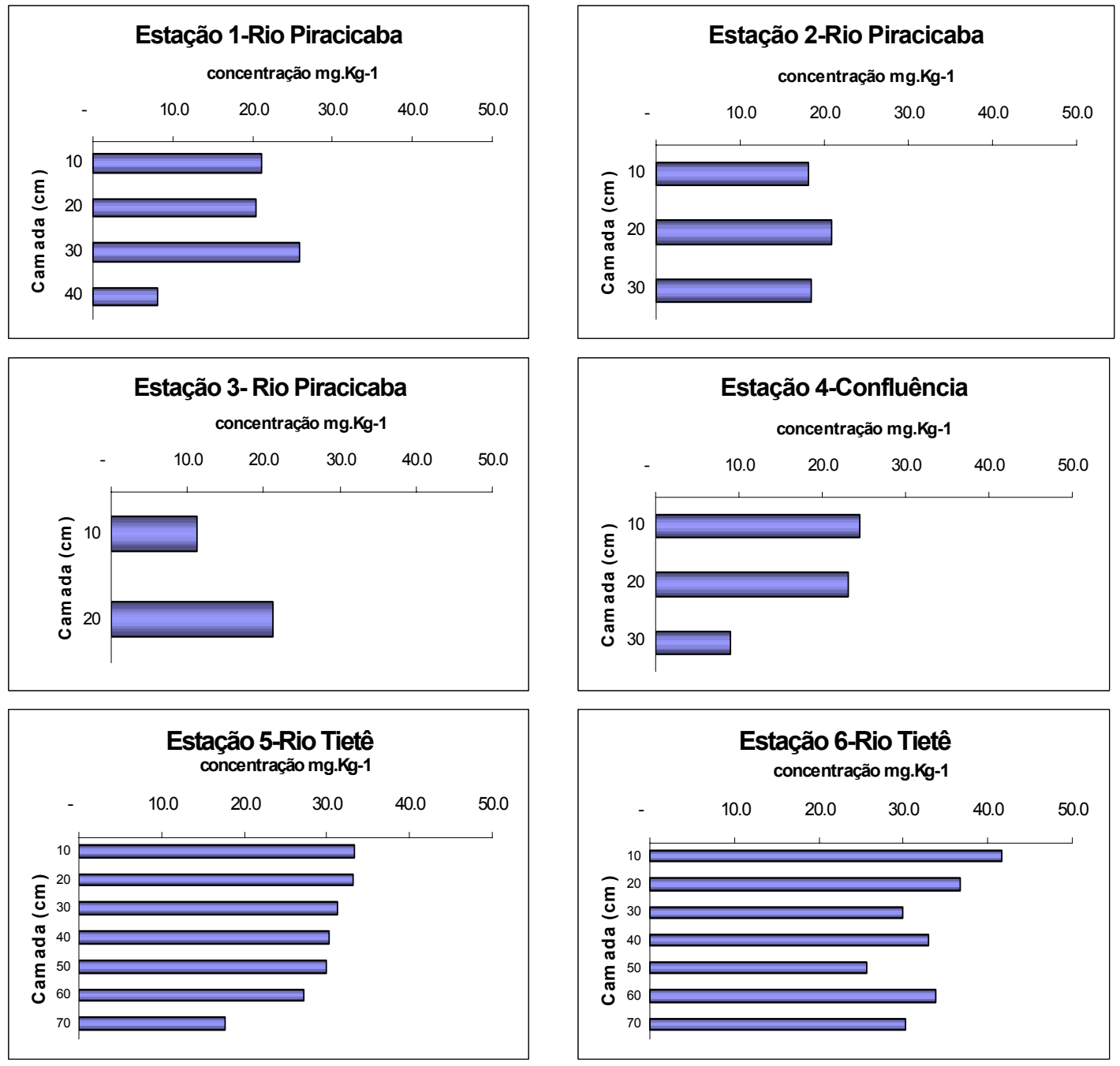

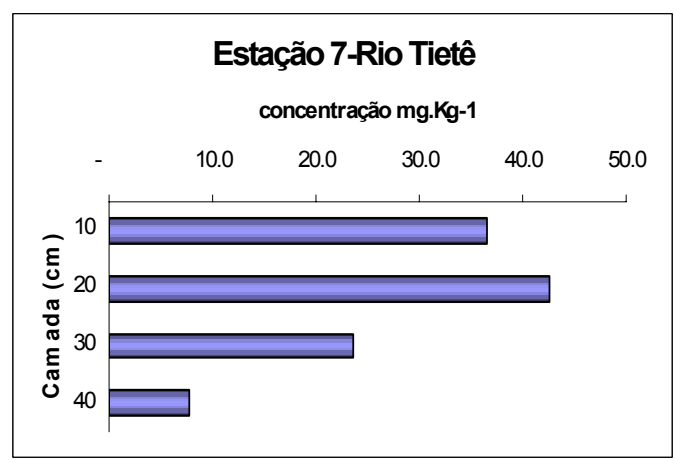

Figura 12: Concentração de zinco potencialmente biodisponível no perfil de sedimento, nas diferentes estações de coleta 

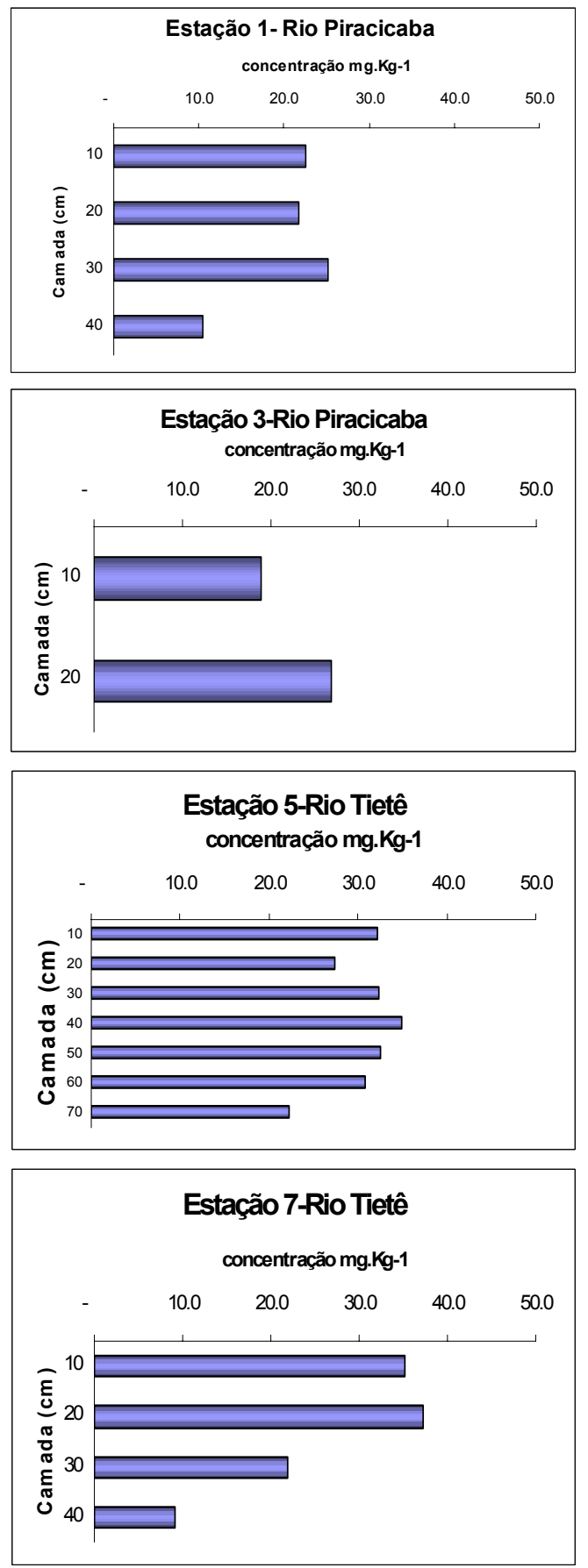
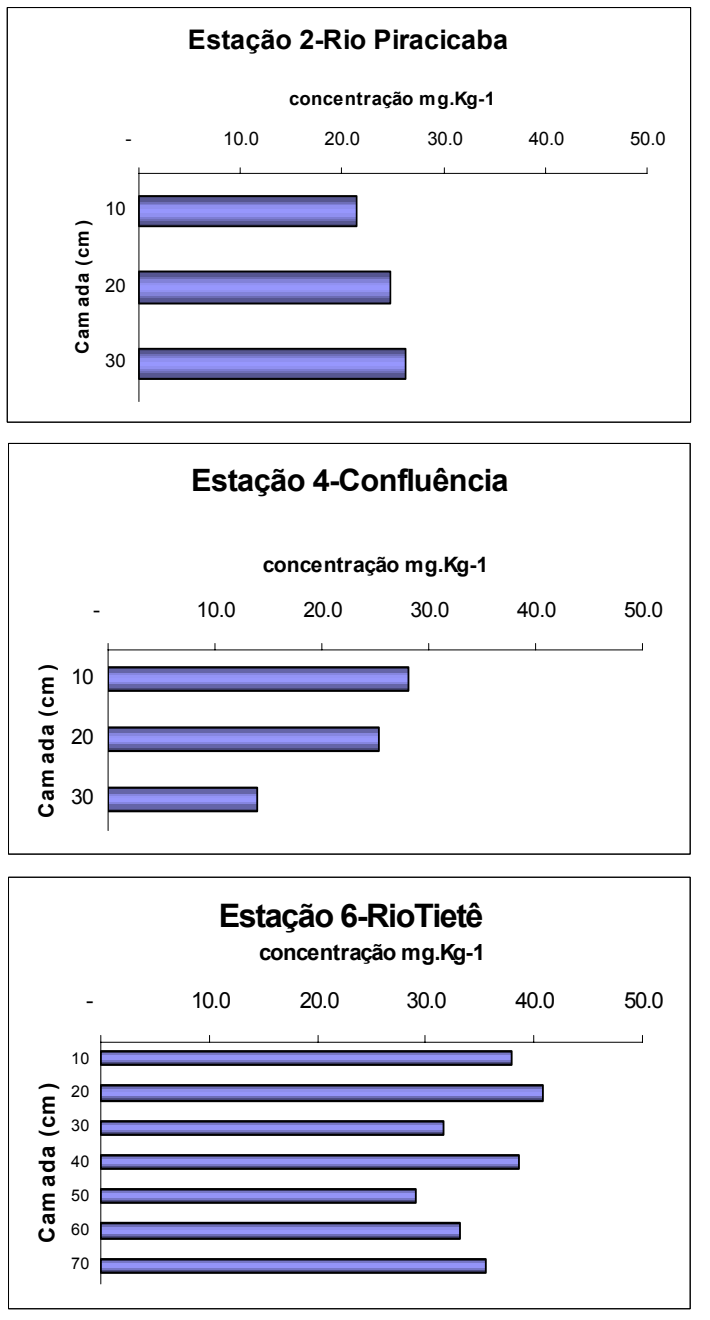

Figura 13: Concentração de cobre potencialmente biodisponível no perfil de sedimento, nas diferentes estações de coleta 
Cádmio- Na estação 1 (rio Piracicaba) foi obtida a menor concentração $\left(1,3 \mathrm{mg} \cdot \mathrm{kg}^{-1}\right)$ na camada de $40 \mathrm{~cm}$ e a maior concentração foi observada na estação 6 (rio Tietê), com 5,9 mg. $\mathrm{kg}^{-1}$, na camada de $70 \mathrm{~cm}$, como mostra a Figura 14. TONISSI (1999), obteve concentrações inferiores no Reservatório de Salto Grande, com valores de 0,25 mg.kg- ${ }^{1}$, detectado em apenas um evento amostral. COSTA (2001) encontrou concentrações inferiores no Reservatório de Barra Bonita, com o valor máximo de $0,013 \mathrm{mg} \cdot \mathrm{kg}^{-1} \mathrm{de}$ cádmio biodisponível. DORNFELD (2002), encontrou valores médios de 0,030 mg.kg ${ }^{-1}$ em amostras de sedimento da represa do Lobo e seus tributários.

Na Tabela 05 são apresentados os percentuais de cádmio potencialmente biodisponível, a partir dos sedimentos, em cada sub-amostra. As frações potencialmente biodisponíveis de cádmio apresentam variações entre 22,9 \% na estação 3 (rio Piracicaba) e 100\% na estação 1 (rio Piracicaba). TONISSI (1999) obteve frações biodisponíveis de cádmio entre 30\% e 40\%. LEITE (2002), neste mesmo reservatório obteve valores de $100 \%$ de biodisponibilidade de cádmio em aproximadamente $90 \%$ das amostras. 

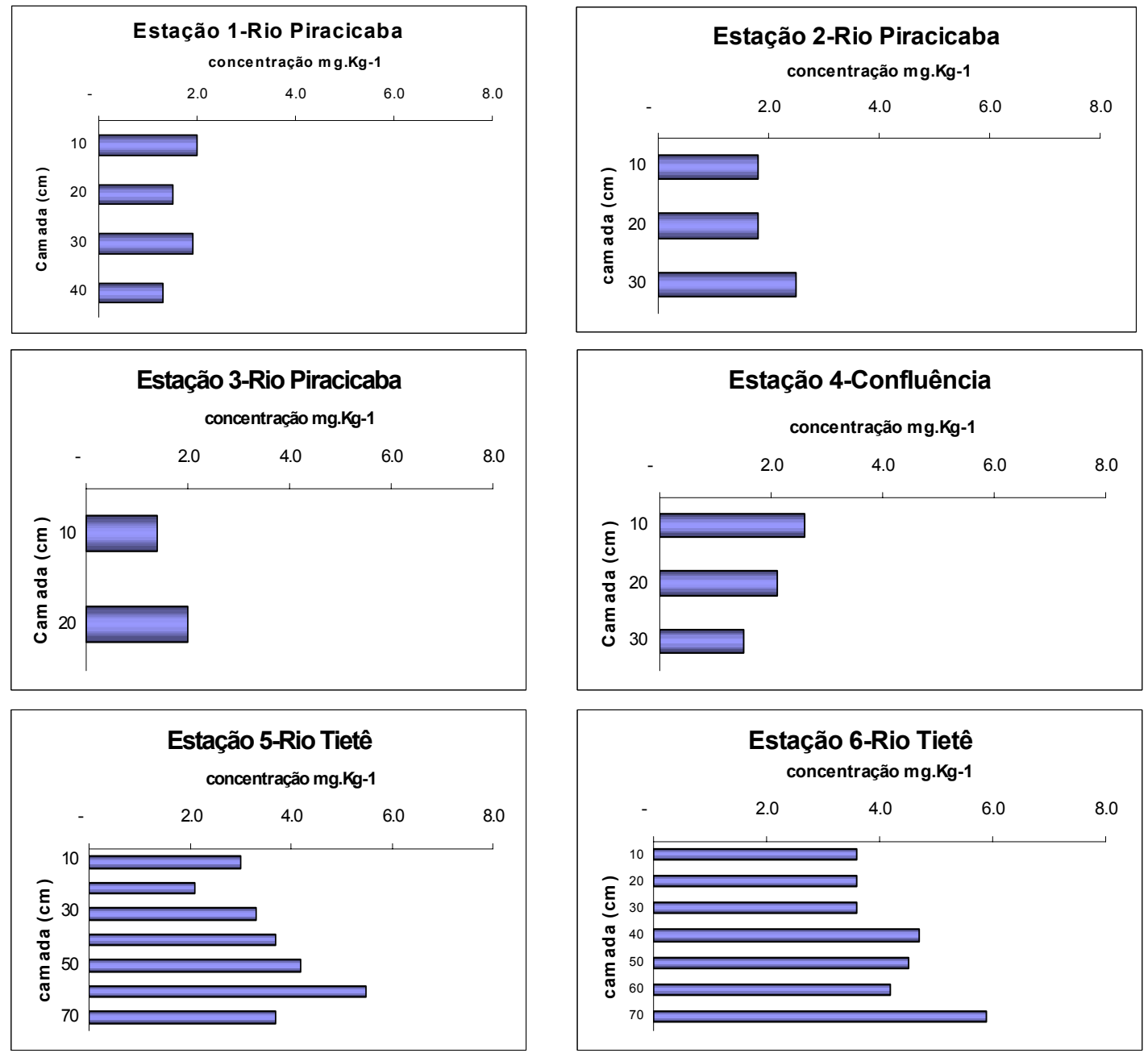

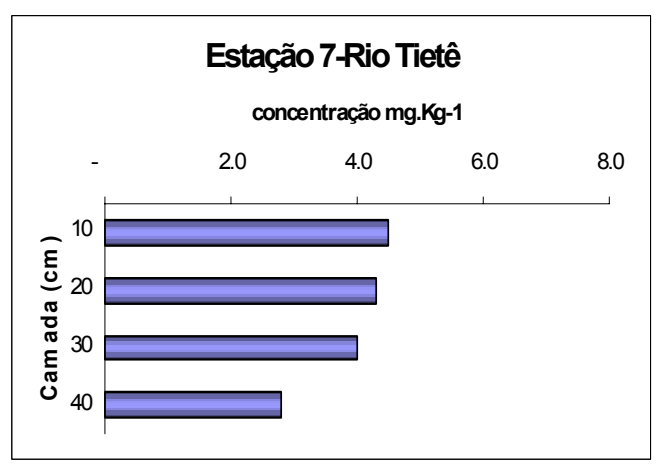

Figura 14: Concentração de cádmio potencialmente biodisponível no perfil de sedimento, nas diferentes estações de coleta 
Tabela 05: Relação entre as concentrações de cádmio total e potencialmente biodisponível obtidas em amostras de sedimento do compartimento de entrada do Reservatório de Barra Bonita

\begin{tabular}{|c|c|c|c|c|}
\hline Estação & Camada (cm) & $\begin{array}{l}\text { Cd Total } \\
\left(\mathrm{mg}^{2} \mathrm{~kg}^{-1}\right)\end{array}$ & $\begin{array}{l}\text { Cd Biod. } \\
\left(\mathrm{mg}^{2} \mathrm{~kg}^{-1}\right)\end{array}$ & $\%$ Biod \\
\hline \multirow[t]{4}{*}{1} & 10 & 1.5 & 2 & $1 \overline{100,0}$ \\
\hline & 20 & 3.7 & 1.5 & 40,5 \\
\hline & 30 & 3.6 & 1.9 & 52,7 \\
\hline & 40 & 3.4 & 1.3 & 38,2 \\
\hline \multirow[t]{3}{*}{2} & 10 & 4 & 1.8 & 45,0 \\
\hline & 20 & 4.6 & 1.8 & 39,1 \\
\hline & 30 & 5.2 & 2.5 & 48,1 \\
\hline \multirow[t]{2}{*}{3} & 10 & 6.1 & 1.4 & 22,9 \\
\hline & 20 & 4.8 & 2 & 41,6 \\
\hline \multirow[t]{3}{*}{4} & 10 & 5 & 2.6 & 52,0 \\
\hline & 20 & 5.7 & 2.1 & 36,8 \\
\hline & 30 & 5.5 & 1.5 & 27,3 \\
\hline \multirow[t]{7}{*}{5} & 10 & 5.2 & 3 & 57,7 \\
\hline & 20 & 5.1 & 2.1 & 41,2 \\
\hline & 30 & 6.2 & 3.3 & 53,2 \\
\hline & 40 & 6.4 & 3.7 & 57,2 \\
\hline & 50 & 5.9 & 4.2 & 71,2 \\
\hline & 60 & 6.9 & 5.5 & 79,7 \\
\hline & 70 & 6.6 & 3.7 & 56,1 \\
\hline \multirow[t]{7}{*}{6} & 10 & 6 & 3.6 & 60,0 \\
\hline & 20 & 6.8 & 3.6 & 52,9 \\
\hline & 30 & 6.2 & 3.6 & 58,1 \\
\hline & 40 & 6.5 & 4.7 & 72,3 \\
\hline & 50 & 6.8 & 4.5 & 66,2 \\
\hline & 60 & 6.4 & 4.2 & 65,6 \\
\hline & 70 & 7.2 & 5.9 & 81,9 \\
\hline \multirow[t]{4}{*}{7} & 10 & 6.3 & 4.5 & 71,4 \\
\hline & 20 & 7.8 & 4.3 & 55,1 \\
\hline & 30 & 7.2 & 4 & 55,5 \\
\hline & 40 & 8.2 & 2.8 & 34,1 \\
\hline
\end{tabular}

Cromo- Na Figura 15 são apresentados os resultados das concentrações de cromo potencialmente biodisponível. Verifica-se que a menor concentração de cromo 
biodisponível foi obtida na estação 1 (rio Piracicaba), com 3,0 mg. $\mathrm{kg}^{-1}$ nas camadas de $10 \mathrm{~cm}$ e de $40 \mathrm{~cm}$ e a maior concentração na estação 6 (rio Tietê), com $26,4 \mathrm{mg} \cdot \mathrm{kg}^{-1}$ na camada de $20 \mathrm{~cm}$. SILVÉRIO (1999), na represa de Billings, encontrou valores máximos de 53,0mg. $\mathrm{kg}^{-1}$ e em Barra Bonita de $6,0 \mathrm{mg} \cdot \mathrm{kg}^{-1}$. A autora verificou um padrão de concentrações mais elevadas nas camadas mais profundas do perfil, o que também foi verificado no presente estudo, com exceção das estações 4 e 7 . LEITE (2002), encontrou concentrações médias superiores, com valores entre 4, 71 e 10,81 $\mathrm{mg} \cdot \mathrm{Kg}^{-1}$.

Com relação a fração biodisponível de cromo todas as estações apresentaram $100 \%$ de biodisponibilidade. TONISSI (1999), obteve o mesmo padrão em amostras de sedimento do reservatório de Salto Grande, no entanto, LEITE (2002) obteve a máxima fração biodisponível em torno de $30 \%$, neste mesmo reservatório.

Chumbo- Na Figura 16 são apresentadas as concentrações de chumbo potencialmente biodisponível ao sitema, a partir dos sedimentos. A maior concentração foi verificada na estação 7 (rio Tietê), com 204,0 mg. $\mathrm{kg}^{-1}$, na camada de $20 \mathrm{~cm}$. A menor concentração foi observada na estação 1 (rio Piracicaba), com 45,0 mg. $\mathrm{kg}^{-1}$. Os maiores valores obtidos por COSTA (2001) são de $0,13 \mathrm{mg} \cdot \mathrm{kg}^{-1}$ ( rio Tietê, mais próximo do represamento); $0,1 \mathrm{mg} \cdot \mathrm{kg}^{-1}$ (rio Capivari) e $0,1 \mathrm{mg} \cdot \mathrm{kg}^{-1}$ (rio Tietê). No sedimento, a absorção de $\mathrm{Pb}$ ocorre principalmente devido ao conteúdo orgânico e ao tamanho do grão. Em casos de poluição extrema, o chumbo se acumula em peixes (MOORE \& RAMAMOORTHY,1984). DORNFELD (2002), analisando sedimentos da represa do Lobo e seus tributários encontrou a concentração máxima de $60,72 \mathrm{mg} \cdot \mathrm{kg}^{-1}$ de chumbo biodisponível, nas estações próximas à barragem.

Na Tabela 06 são apresentados os percentuais de chumbo potencialmente biodisponível, a partir dos sedimentos, em cada sub-amostra. As frações biodisponíveis de chumbo sofreram grandes variações, entre 34,7\% e 100\%, sendo que estes valores são considerados altos em termos de biodisponibilidade. TONISSI (1999) obteve uma variação de $9,8 \%$ a $73,2 \%$ de biodisponibilidade de chumbo em sedimentos do reservatório de Salto Grande. 

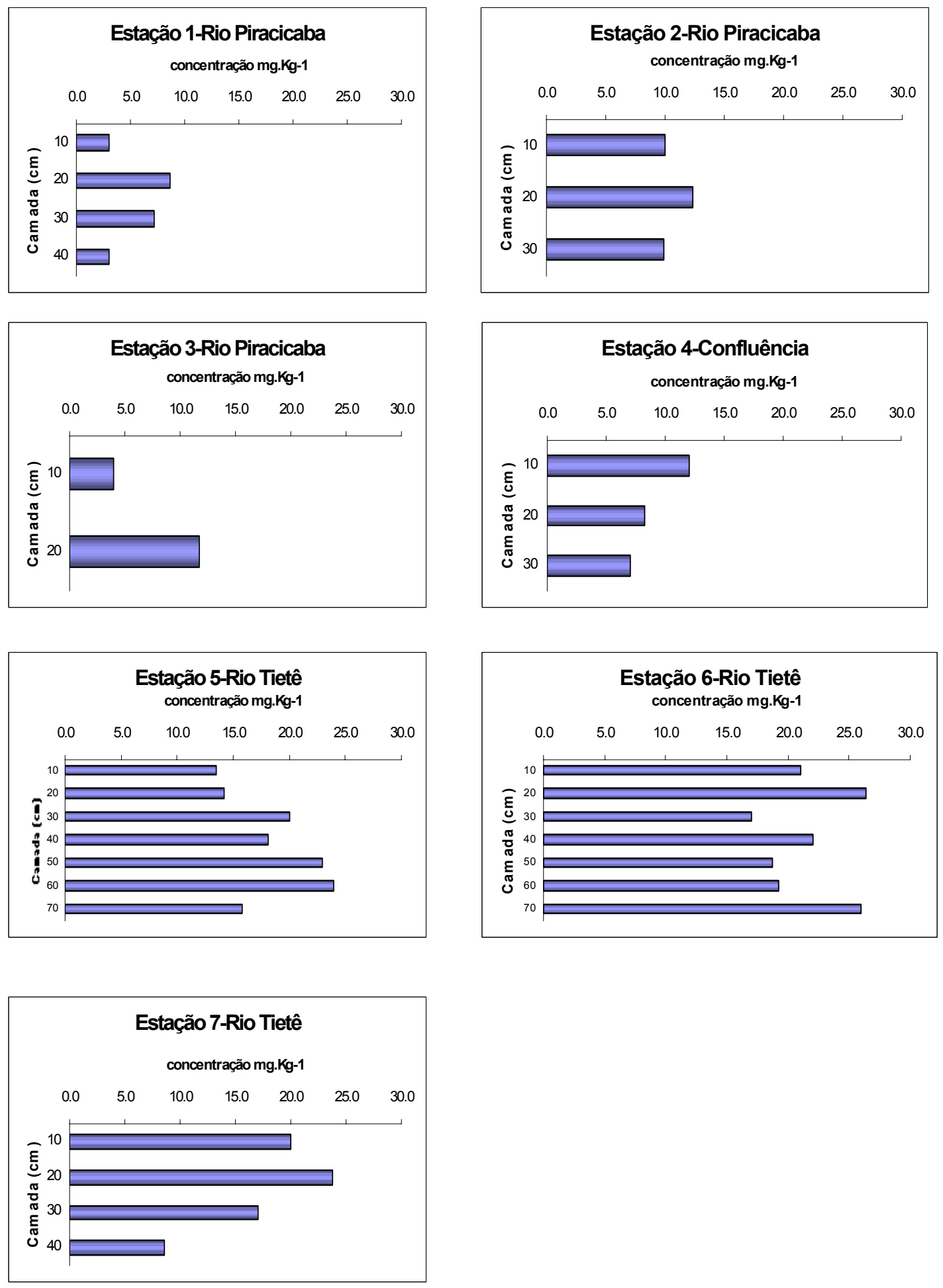

Figura 15: Concentração de cromo potencialmente biodisponível no perfil de sedimento, nas diferentes estações de coleta 

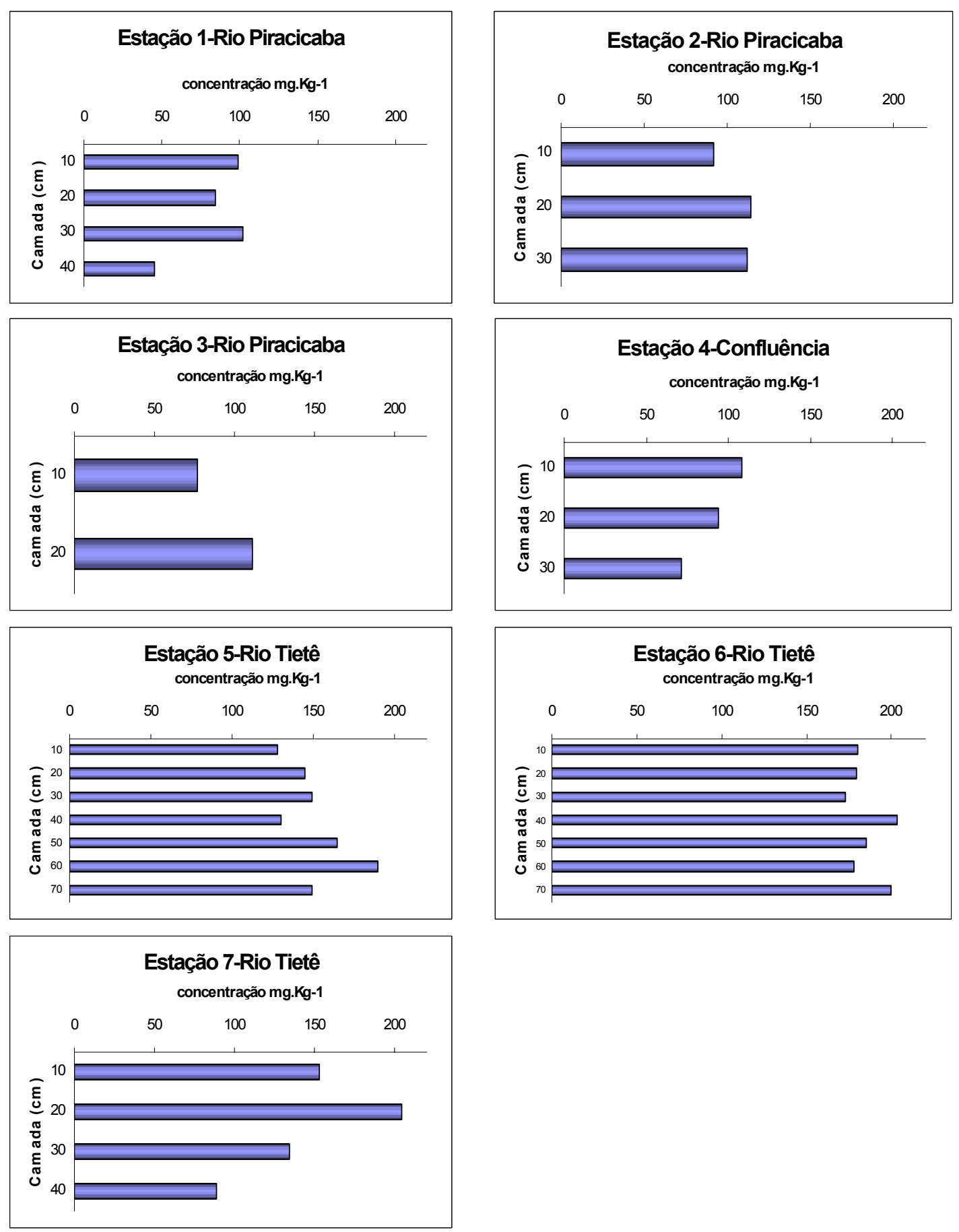

Figura 16: Concentração de chumbo potencialmente biodisponível no perfil de sedimento, nas diferentes estações de coleta 
Tabela 06: Relação entre as concentrações de chumbo total e potencialmente biodisponível obtidas em amostras de sedimento do compartimento de entrada do Reservatório de Barra Bonita

\begin{tabular}{|c|c|c|c|c|}
\hline Estação & Camada (cm) & $\begin{array}{l}\text { Pb Total } \\
\left(\mathrm{mg.kg}^{-1}\right)\end{array}$ & $\begin{array}{l}\text { Pb Biod. } \\
\left(\mathrm{mg.kg}^{-1}\right)\end{array}$ & $\%$ Biod \\
\hline \multirow[t]{4}{*}{1} & 10 & 0 & 99 & 100,0 \\
\hline & 20 & 0 & 84 & 100,0 \\
\hline & 30 & 60 & 102 & 100,0 \\
\hline & 40 & 0 & 45 & 100,0 \\
\hline \multirow[t]{3}{*}{2} & 10 & 195 & 92 & 47,2 \\
\hline & 20 & 144 & 114 & 79,2 \\
\hline & 30 & 206 & 112 & 54,4 \\
\hline \multirow[t]{2}{*}{3} & 10 & 91 & 77 & 84,6 \\
\hline & 20 & 173 & 111 & 64,2 \\
\hline \multirow[t]{3}{*}{4} & 10 & 312 & 108 & 34,6 \\
\hline & 20 & 198 & 94 & 47,5 \\
\hline & 30 & 101 & 71 & 70,3 \\
\hline \multirow[t]{7}{*}{5} & 10 & 159 & 128 & 80,5 \\
\hline & 20 & 92 & 145 & 100,0 \\
\hline & 30 & 153 & 149 & 97,4 \\
\hline & 40 & 246 & 130 & 52,8 \\
\hline & 50 & 101 & 165 & 100,0 \\
\hline & 60 & 18 & 190 & 100,0 \\
\hline & 70 & 82 & 149 & 100,0 \\
\hline \multirow[t]{7}{*}{6} & 10 & 99 & 180 & 100,0 \\
\hline & 20 & 116 & 179 & 100,0 \\
\hline & 30 & 217 & 173 & 79,7 \\
\hline & 40 & 216 & 203 & 93,9 \\
\hline & 50 & 282 & 185 & 65,6 \\
\hline & 60 & 198 & 178 & 89,9 \\
\hline & 70 & 212 & 200 & 94,3 \\
\hline \multirow[t]{4}{*}{7} & 10 & 288 & 153 & 53,1 \\
\hline & 20 & 175 & 204 & 100,0 \\
\hline & 30 & 161 & 134 & 83,2 \\
\hline & 40 & 88 & 89 & 100,0 \\
\hline
\end{tabular}


Níquel- Na Figura 17 são apresentados os resultados das concentrações de níquel biodisponível, nas diferentes estações de coleta. A maior concentração foi verificada na estação 5 (rio Tietê), com 13,4 mg. $\mathrm{kg}^{-1}$ de níquel biodisponível na camada de $40 \mathrm{~cm}$. A menor concentração foi de $1,6 \mathrm{mg} \cdot \mathrm{kg}^{-1}$, na estação 1 (rio Piracicaba), camada de $40 \mathrm{~cm}$. TONISSI (1999), obteve uma concentração média de níquel biodisponível de 9,08 mg. $\mathrm{Kg}^{-1}$ nos sedimentos do reservatório de Salto Grande. ESTEVES et al. (1991), obteve valores médios de $5,6 \mathrm{mg} \cdot \mathrm{kg}^{-1}$ de níquel biodisponível $\mathrm{n}$ camada superficial de sedimentos pertencentes à várias represas do Sistema Paranapanema, Paraná, Rio Grande, Rio Pardo e Tietê.

Na Tabela 07 são apresentados os percentuais de níquel potencialmente biodisponível, a partir dos sedimentos, em cada sub-amostra. As frações biodisponíveis de níquel variam de $15,7 \%$ a $100 \%$. Verifica-se alta mobilidade deste elemento nas camadas amostradas, sendo que aproximadamente $70 \%$ das amostras apresentam $100 \%$ de biodisponibilidade de níquel a partir dos sedimentos. 

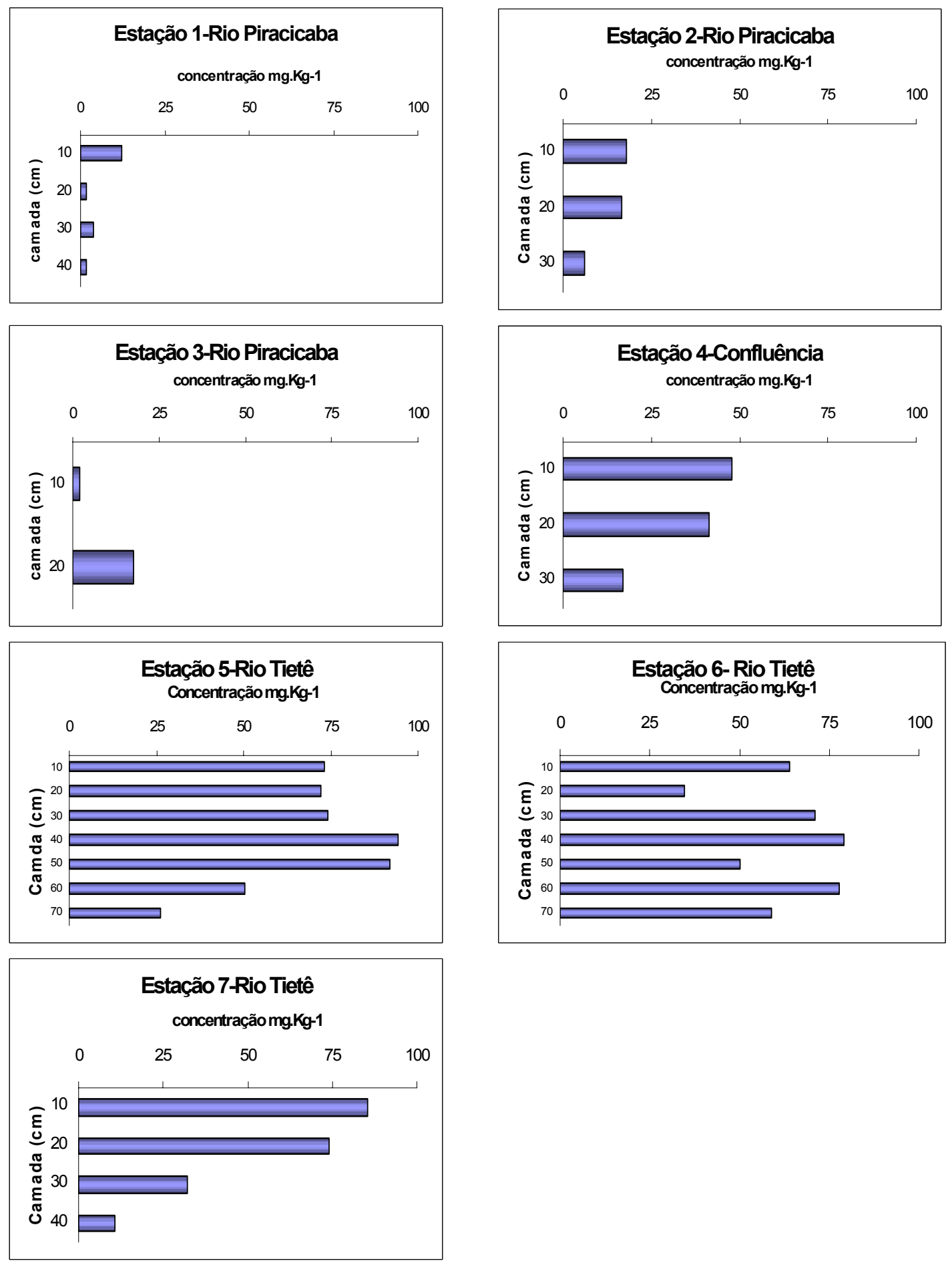

Figura 17: Concentração de níquel potencialmente biodisponível no perfil de sedimento, nas diferentes estações de coleta. 
Tabela 07: Relação entre as concentrações de níquel total e potencialmente biodisponível obtidas em amostras de sedimento do compartimento de entrada do Reservatório de Barra Bonita

\begin{tabular}{|c|c|c|c|c|}
\hline Estação & Camada (cm) & $\begin{array}{l}\text { Ni Total } \\
\left(\mathrm{mg.kg}^{-1}\right)\end{array}$ & $\begin{array}{l}\text { Ni Biod. } \\
\left(\mathrm{mg.kg}^{-1}\right)\end{array}$ & \% Biod. \\
\hline \multirow[t]{4}{*}{1} & 10 & 0 & 12.4 & 100,0 \\
\hline & 20 & 6.5 & 1.9 & 29,2 \\
\hline & 30 & 6.6 & 4 & 60,6 \\
\hline & 40 & 10.2 & 1.6 & 15,7 \\
\hline \multirow[t]{3}{*}{2} & 10 & 10.8 & 18 & 100,0 \\
\hline & 20 & 5.6 & 16.7 & 100,0 \\
\hline & 30 & 9.1 & 6 & 65,9 \\
\hline \multirow[t]{2}{*}{3} & 10 & 9.3 & 2.2 & 23,6 \\
\hline & 20 & 12.2 & 17.5 & 100,0 \\
\hline \multirow[t]{3}{*}{4} & 10 & 18.3 & 47.8 & 100,0 \\
\hline & 20 & 12.6 & 41.3 & 100,0 \\
\hline & 30 & 20.1 & 17 & 84,6 \\
\hline \multirow[t]{7}{*}{5} & 10 & 21 & 73 & 100,0 \\
\hline & 20 & 10.5 & 72.1 & 100,0 \\
\hline & 30 & 20.1 & 74 & 100,0 \\
\hline & 40 & 30.6 & 94.2 & 100,0 \\
\hline & 50 & 16.8 & 92 & 100,0 \\
\hline & 60 & 25.8 & 50.5 & 100,0 \\
\hline & 70 & 27.3 & 26.3 & 96,3 \\
\hline \multirow[t]{7}{*}{6} & 10 & 23.2 & 64 & 100,0 \\
\hline & 20 & 23 & 34.8 & 100,0 \\
\hline & 30 & 22 & 71 & 100,0 \\
\hline & 40 & 17.2 & 79.2 & 100,0 \\
\hline & 50 & 28.8 & 50 & 100,0 \\
\hline & 60 & 29.3 & 77.9 & 100,0 \\
\hline & 70 & 20.4 & 59 & 100,0 \\
\hline \multirow[t]{4}{*}{7} & 10 & 27.6 & 85.4 & 100,0 \\
\hline & 20 & 25.6 & 74 & 100,0 \\
\hline & 30 & 24.2 & 32.2 & 100,0 \\
\hline & 40 & 22.4 & 10.8 & 48,2 \\
\hline
\end{tabular}




\subsubsection{ANÁLISE ESTATÍSTICA}

A análise de PCA foi realizada correlacionando os metais totais, os biodisponíveis, o teor de matéria orgânica e a granulometria das amostras.

O percentual de variância acumulada obtido foi de $79,75 \%$, o que incluiu metais biodisponíveis e granulometria. O primeiro componente (metais biodisponíveis) explicou 65,028\% da variância, e o segundo componente (granulometria) explicou 14,721\%, conforme a Tabela 08.

Tabela 08: Relação dos principais componentes da análise, e percentual da variância explicada.

\begin{tabular}{|c|c|c|}
\hline Variáveis & $\begin{array}{c}\text { Componente principal 1 } \\
\text { (metais biodisponíveis) }\end{array}$ & $\begin{array}{c}\text { Componente principal 2 } \\
\text { (granulometria) }\end{array}$ \\
\hline $\mathrm{Cu}$ & 0.941 & 0.133 \\
\hline $\mathrm{Pb}$ & 0.929 & 0.003 \\
\hline $\mathrm{Zn}$ & 0.929 & 0.148 \\
\hline $\mathrm{Cr}$ & 0.895 & 0.096 \\
\hline $\mathrm{Fe}$ & 0.857 & -0.046 \\
\hline $\mathrm{Ni}$ & 0.847 & 0.250 \\
\hline $\mathrm{Mn}$ & 0.802 & -0.007 \\
\hline $\mathrm{Cd}$ & 0.798 & -0.022 \\
\hline Porção siltosa & 0.233 & -0.919 \\
\hline Porção argilosa & -0.376 & 0.859 \\
\hline Total da Variância Explicada & $\mathbf{6 5 . 0 2 8}$ & $\mathbf{1 4 . 7 2 1}$ \\
\hline Total & & \\
\hline
\end{tabular}

Desta forma, pode-se inferir que a granulometria das amostras regula o potencial de biodisponibilidade, embora a MANOVA não tenha resultado em correlação significativa $(p>0,05)$ entre os dados analisados e os metais biodisponíveis e totais. No entanto, ressalta-se a importância de se considerar outras variáveis que influenciam os processos de adsorção/ mobilização de metais em sedimentos, que não foram analisados neste estudo. 
A fração potencialmente biodisponível é influenciada por um grande número de fatores, principalmente $\mathrm{pH}$ e potencial redox, o que caracteriza o sedimento como sistema extremamente dinâmico.

$\mathrm{Na}$ Figura 18 é apresentado o Cluster formado a partir do agrupamento das amostras em função das variáveis selecionadas na PCA. O processamento das etapas de agrupamento e ligação resulta em uma matriz cofenética e, comparando-se esta com a matriz de associação, tem-se o coeficiente de correlação cofenética que permite avaliar o grau de distorção proporcionado pela análise sobre os dados originais. De acordo com LEGENDRE (1983), são aceitáveis os índices superiores a 0.80 . O coeficiente de correlação cofenética obtido neste estudo foi de 0.9089 , resultando, portanto, em pouca distorção dos dados originais. Optou-se pelo agrupamento pela associação não ponderada (UPGMA), por atribuir similaridade entre pares de grupos de forma menos extrema, sendo que esta análise foi realizada no intuito de verificar a similaridade entre as estações de coleta.

Ao nível de corte de 800, na distância euclidiana média, observa-se a formação de 5 grupos distintos:

Grupo 1: próximos a distancia euclidiana média "zero", o que representa altíssimo grau de similaridade entre as amostras. O grupo é formado pela Estação 1 (camada $20 \mathrm{~cm}$ e $30 \mathrm{~cm}$ ), Estação 2 (camada $20 \mathrm{~cm}$ ), Estação 3 (camada $20 \mathrm{~cm}$ ), Estação 4 (camada $20 \mathrm{~cm}$ ), Estação 5 (camada $10 \mathrm{~cm}, 20 \mathrm{~cm}, 50 \mathrm{~cm}$ e $60 \mathrm{~cm}$ ), Estação 6 (camada 30 cm) e Estação 7 (camada $10 \mathrm{~cm}$ ).

Grupo 2: localizado à distância euclidiana média de 380. O grupo é formado pela Estação 1 (camada $10 \mathrm{~cm}$ ), Estação 2 (camada $10 \mathrm{~cm}$ e $30 \mathrm{~cm}$ ), Estação 4 (camada $10 \mathrm{~cm}$ ), Estação 5 (camada $30 \mathrm{~cm}, 40 \mathrm{~cm}, 70 \mathrm{~cm}$ ) e Estação 6 (camada $10 \mathrm{~cm}, 50 \mathrm{~cm}$, $60 \mathrm{~cm})$.

Grupo 3: localizado à distância euclidiana média de 390. O grupo é formado pela Estação 3 (camada 10cm), Estação 4 (camada $30 \mathrm{~cm}$ ), Estação 6 (camada 20cm, 40cm) e Estação 7 (camada 20cm, 40cm)

Grupo 4: com distância euclidiana média 1000. É formado pela estação 1 (camada 40 $\mathrm{cm})$

Grupo 5: com distância euclidiana média 1000. É formado pela estação 6 (camada 70 $\mathrm{cm})$ 


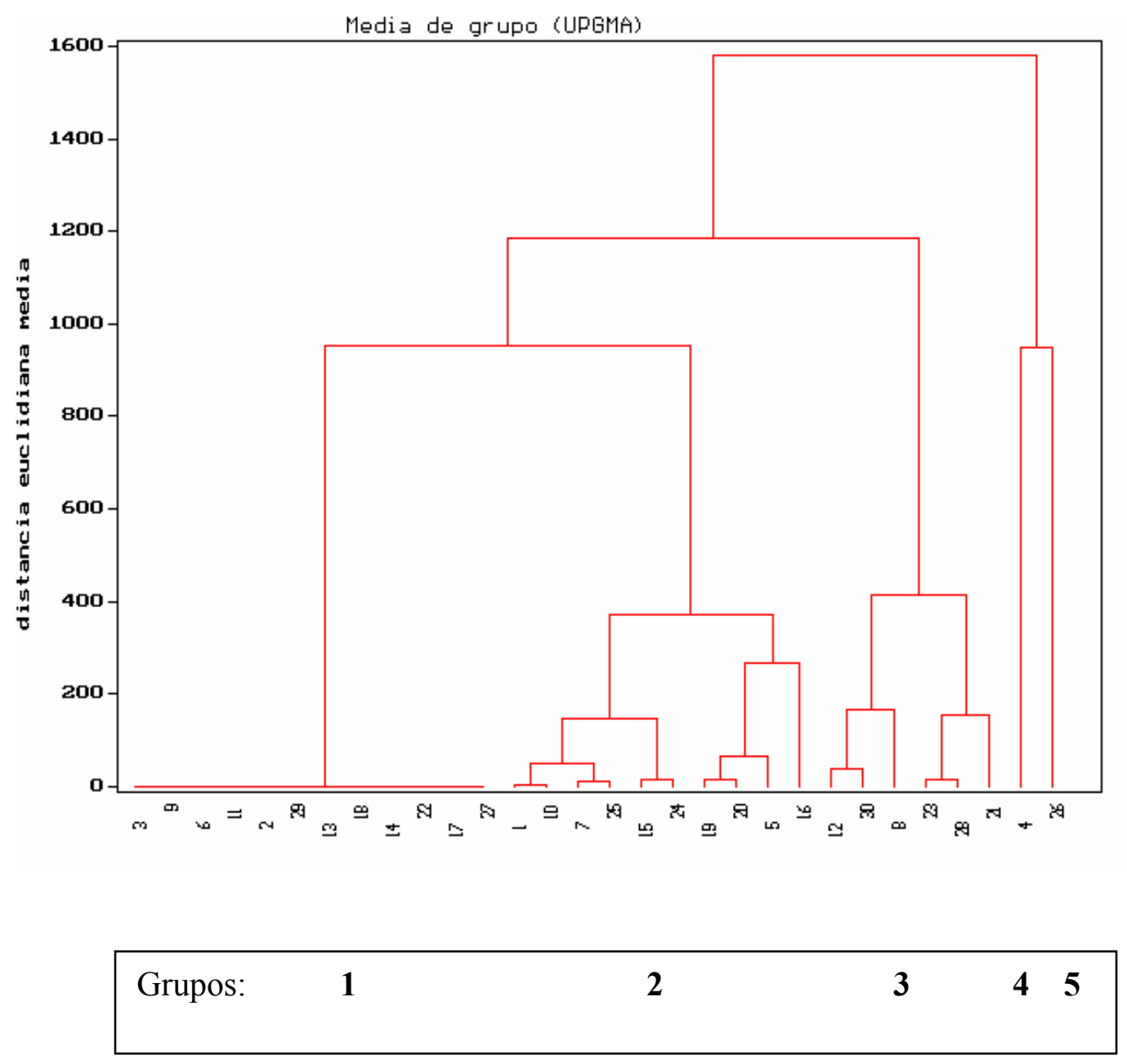

Figura 18: Cluster formado a partir do agrupamento das amostras de acordo com a biodisponibilização de metais.

Verifica-se que as amostras pertencentes ao grupo 1 (com alto grau de similaridade) são predominantemente representadas por camadas superficiais do sedimento, praticamente abrangendo as camadas entre 10 e $30 \mathrm{~cm}$ de todas as estações de coleta. O grupo 2 apresenta principalmente as estações 5 e 6 , de forma que pode-se observar que estes testemunhos apresentam similaridades ao longo do perfil de 
sedimentos, com diferenças pouco pronunciadas entre as sub-amostras. O grupo 3 é formado pelas amostras que apresentaram os maiores e menores valores de cádmio, ferro e zinco, apresentando ainda os menores valores de cobre e os maiores valores de chumbo. O grupo 4 corresponde as amostras com os menores valores de cromo, chumbo e níquel e o grupo 5 apresenta a amostra com os maiores valores de manganês e cádmio.

Verifica-se que os agrupamentos 3 e 5 englobaram as amostras com as maiores concentrações de metais potencialmente biodisponíveis, mobilizados principalmente a partir das camadas superficiais dos sedimentos pertencentes as Estações 6 e 7, ambas localizadas no rio Tietê. Verifica-se ainda uma diminuição acentuada nas concentrações biodisponíveis de cádmio ao longo do perfil de sedimento da estação 7. A camada de 20 $\mathrm{cm}$, da estação 7, apresentou os maiores valores de $\mathrm{Fe}, \mathrm{Zn}$ e $\mathrm{Pb}$, e a camada de $40 \mathrm{~cm}$ os menores valores de $\mathrm{Fe}, \mathrm{Zn}, \mathrm{Mn}$ e $\mathrm{Cu}$. A camada de $20 \mathrm{~cm}$ apresenta menor fração de argila em relação a camada de $40 \mathrm{~cm}$. Além do fator adsorção como regulador dos mecanismos de biodisponibilização de metais, possivelmente existem outros fatores que no ambiente de estudo influenciam mais diretamente este potencial .

\subsubsection{Geocronologia de ${ }^{210} \mathrm{~Pb}$}

Os termos geocronologia, cronologia ou datação podem ser considerados como sinônimos em se tratando da determinação das idades dos sedimentos depositados em ambientes aquáticos. É muito importante, para estudos ambientais pretéritos, a existência de ambientes que acumulem materiais que, quando quantificados, permitam uma visão ambiental das ocorrências do passado (CAZOTTI, 2002)

$\mathrm{O}{ }^{210} \mathrm{~Pb}$, pertencente às séries naturais do ${ }^{238} \mathrm{U}$, é um dos mais utilizados em geocronologia, pois, além de se estabilizarem físico-quimicamente apresentam um decaimento radioativo bem definido em função do tempo. $\mathrm{O}{ }^{210} \mathrm{~Pb}$ atmosférico é depositado juntamente com as camadas de sedimento, ocorrendo o decaimento de acordo com a lei do decaimento radioativo. Desta forma, conhecendo-se a atividade inicial do ${ }^{210} \mathrm{~Pb}$, que pode ser medida ou estimada e considerando que a mesma se mantém constante durante o período considerado, pode-se determinar o tempo de residência ou a idade de um determinado depósito, desde que, também não tenham ocorrido modificações significativas. 
De acordo com CAZOTTI (2002), em ambientes eutrofizados e, localizados geralmente em locais de maior urbanização ocorrem perturbações no sedimento, tanto física como quimicamente e com variações significativas na velocidade de deposição do sedimento. Quando isto ocorre, os valores de ${ }^{210} \mathrm{~Pb}$ obtidos nas amostras de um perfil de sedimento, plotados logaritmicamente em função da profundidade, apresentará pouca ou, quase nenhuma linearidade.

Os testemunhos de sedimentos do Reservatório de Barra Bonita apresentaram pouca linearidade, constituindo um ambiente de difícil estudo cronológico, devido ao alto grau de interferência antrópica na região de entorno do reservatório. Com exceção do testemunho extraído na estação 5 (rio Tietê), os demais não apresentaram cronologia definida, sendo portanto excluídos da análise.

$\mathrm{Na}$ Figura 19 é apresentado o rendimento de ${ }^{210} \mathrm{~Pb}$, em função da profundidade, no perfil de sedimento da estação 5 (apenas os primeiros $50 \mathrm{~cm}$ apresentaram linearidade). Na Tabela 09 são apresentados os resultados de cronologia dos sedimentos da estação 5, em função da profundidade. A Figura 20 apresenta a cronologia das camadas sedimentares.

O perfil de sedimento coletado na estação 5 corresponde a um período de acumulação de aproximadamente 25 anos, com a camada mais profunda atingindo o ano de 1977. De acordo com os resultados de concentração de metais totais no testemunho da estação 5, é possível verificar que, em relação ao Cobre existe uma forte tendência ao acrescimo deste metal a partir de 1977 (camada de $50 \mathrm{~cm}$ ), período este que coincide com o maior aparecimento de Blooms de algas e consequente aplicação de algicidas como o sulfato de cobre. Pode-se verificar ainda, nos Anexos 03 C e 03 D, que na década de 70 dá-se inicio a um processo de crescimento industrial evidente na região do Médio Tietê superior e na Bacia do rio Piracicaba, principalmente no caso das metalúrgicas. Estes fatores associados podem fornecer informações importantes no que se refere a estudos de histórico de poluição ambiental, no entanto no presente estudo, não poderão ser utilizados com esta finalidade em função da baixa representatividade, dentro do universo dos dados. 


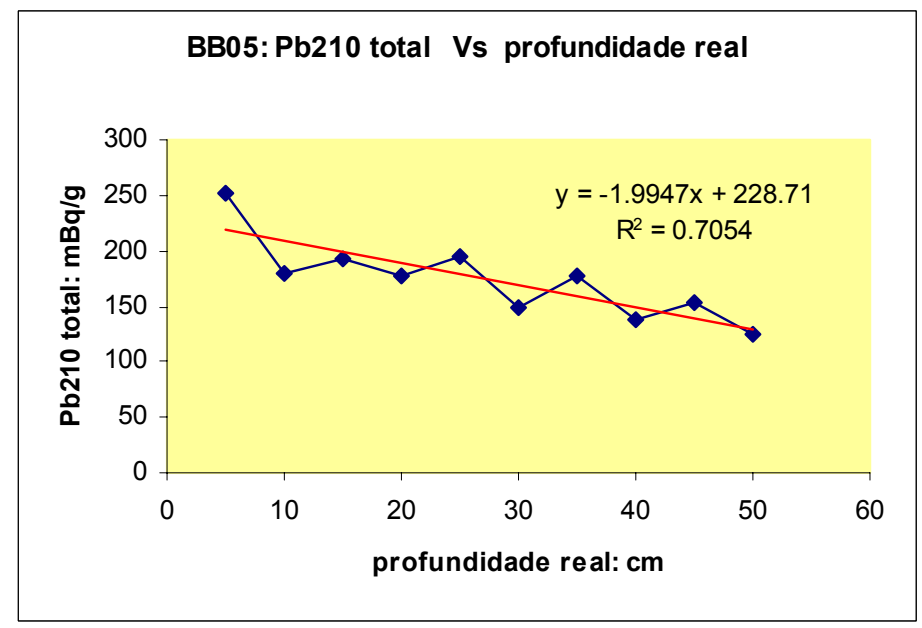

Figura 19: Rendimento $\mathrm{de}^{210} \mathrm{~Pb}$, em função da profundidade, no perfil de sedimento da estação 5 (rio Tietê)

Tabela 09: Data correspondente de cada camada de sedimento no perfil da estação 5 (rio Tietê)

\begin{tabular}{|c|c|}
\hline Profundidade (cm) & Datação \\
\hline 5 & 2000 \\
\hline 10 & 1997 \\
\hline 15 & 1994 \\
\hline 20 & 1992 \\
\hline 25 & 1988 \\
\hline 30 & 1986 \\
\hline 35 & 1982 \\
\hline 40 & 1981 \\
\hline 45 & 1978 \\
\hline 50 & 1977 \\
\hline
\end{tabular}

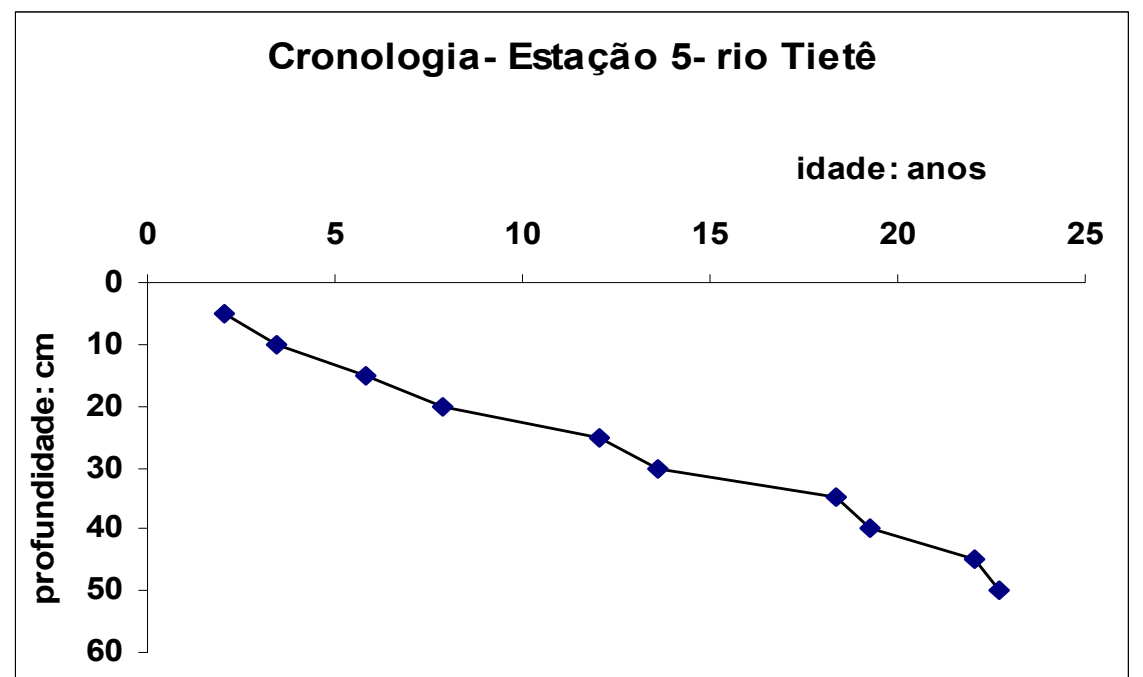




\section{Figura 20 : Geocronologia do perfil de sedimentos da Estação 5 (rio Tietê)}

4.2.5 Desenvolvimento antropogênico em municípios localizados ao longo dos rios Piracicaba e Tietê ou seus tributários.

\subsubsection{URBANIZAÇÃO}

Com a implantação do Reservatório de Barra Bonita na década de 60, observou-se uma evidente expansão e melhoria na malha rodoviária da área de influência do reservatório, contribuindo para a aceleração do processo de urbanização. Observou-se um crescimento de $15 \%$ da população total do entorno do reservatório após o início de seu funcionamento (VALÊNCIO et al.,1999). Neste contexto, a população urbana sofreu um crescimento ainda mais evidente, levando a população rural para uma situação de declínio irreversível, situação que persiste até a atualidade.

Nos Anexos 03 A e 03 B estão apresentados os resultados da análise de crescimento populacional de municípios localizados na bacia do Piracicaba e Médio Tietê Superior (áreas de influência do reservatório), a partir da década de 60. Observa-se um crescimento populacional acelerado nestas regiões, com uma tendência evidente ao crescimento urbano.

Após a implantação do reservatório de Barra Bonita houve mudanças substanciais no que tange ao uso do solo, substituindo em grande parte a cultura do café para dar espaço ao cultivo em larga escala da cana-de-açucar, com vista ao maior desenvolvimento econômico da região (VALÊNCIO et al., 1999). A disponibilidade hídrica e o melhoramento das condições de circulação pelas rodovias promoveram a modernização agrícola.

O êxodo rural, incrementado pela difusão da cultura canavieira, contribuiu para o aumento do desemprego e consequentemente com a maior concentração de pessoas nas áreas urbanas, muitas vezes com o propósito de usufruir dos "benefícios gerados pelo desenvolvimento".

Estimativas apontam que as tendências de ocupação humana estão sendo direcionadas para as cidades de médio porte, sendo a região do Médio Tietê Superior e a bacia do Piracicaba locais bastante atrativos (SEMA, 1984). A situação de insustentabilidade presente nos centros urbanos coloca em questão os paradigmas do desenvolvimento e surge desta forma a intenção de mudança no cenário observado. 
Neste sentido, programas de incentivo à fixação de um contingente populacional na área rural estão sendo implantados, como é o caso do Programa Estadual de Bacias Hidrográficas, um programa do Governo Estadual, que tem como principal meta promover o desenvolvimento rural sustentável no Estado de São Paulo, utilizando a microbacia hidrográfica como unidade de trabalho.

\subsubsection{INDUSTRIALIZAÇÃO}

Os padrões de crescimento demográfico observados resultaram em maior parte dos investimentos industriais que confluíram para a região de influência do reservatório de Barra Bonita, após as melhorias de infra-estrutura no entorno, decorrentes do início das operações da usina (VALÊNCIO et al., 1999). Desta forma, a indústria não se utiliza apenas do espaço físico, mas também desencadeia outras ocupações urbanas, que maximizam os problemas sócio-ambientais.

Nos Anexos 03 C e 03 D estão apresentados os resultados da análise de crescimento industrial (em números de estabelecimento por gênero de industria) de municípios localizados na bacia do Piracicaba e Médio Tietê Superior (áreas de influência do reservatório), a partir da década de 60. Ressalta-se que o IBGE não possui dados disponíveis referentes a década de 1990, já os dados referentes ao ano 2000 não permite a análise separada do universo de dados de acordo com os municípios, fornecendo apenas os dados de uma forma geral, ou seja, por estado ou região. Desta forma, optou-se pela análise apenas dos dados levantados entre 1960 e 1980.

Observa-se, na região do Médio Tietê Superior e Grande São Paulo, que o número total de indústrias tem apresentado crescimento contínuo ao longo dos anos, apresentando padrão semelhante ao crescimento demográfico urbano, na mesma região, exceto o município de Barueri. Verifica-se que alguns setores como o têxtil, no caso de Americana e o metalúrgico nos demais municípios, apresentam um crescimento gradual, destacando-se em relação aos outros setores.

De acordo com VALÊNCIO et al. (1999), a região influenciada pelo reservatório de Barra Bonita apresentou um crescimento industrial de $75 \%$ após o início de seu funcionamento (1963), em relação a década anterior.

O crescimento industrial coloca a região do Médio Tietê Superior e a bacia do Piracicaba, não apenas como desenvolvidas economicamente, mas também como mais suscetíveis aos riscos de degradação ambiental decorrentes da atividade industrial 
Entre os estabelecimentos industriais predominam aqueles pertencentes ao segmento de "potencial poluidor alto", de acordo com os Valores de Complexidade da Fonte de Poluição, atribuídos pelo decreto n 8468 de 08 de setembro de 1976.

A indústria metalúrgica (e seus sub-segmentos como siderurgia, metais não ferrosos, produção de soldas, estamparia), em franco crescimento na região, apresentase na interface de "baixo-alto poluidor". No entanto, a indústria têxtil, fortemente fixada e desenvolvida em Americana, apresenta o mais alto risco de impacto ambiental.

De acordo com VALÊNCIO et al. (1999), até 1960 as industrias da região influenciada pelo reservatório apresentavam baixa expressividade numérica e, a partir de então houve brusca elevação do número de estabelecimentos. Desta forma, aponta-se para a sincronicidade entre a expansão da oferta de energia e o nível dos investimentos, transformando intensamente o cenário urbano dos municípios em questão.

\subsubsection{AGRICULTURA}

Os Anexos 03 E e 03 F permitem avaliar a quantidade de propriedades rurais, em hectares, de municípios localizados na bacia do Piracicaba e Médio Tietê Superior (áreas de influência do reservatório), a partir da década de 60. A partir de então, os processos de industrialização do campo tornaram-se mais evidentes, com a adição pesada de insumos químicos, mecanização substituindo a mão de obra do homem e uso intensivo do solo.

De acordo com WEBER (1967) pode-se dizer que o mundo rural perdeu o "encantamento" pois passou a apresentar uma dinâmica com base na racionalização progressiva da produção. As alterações do padrão produtivo na área de influência do reservatório podem ser observadas pela mudança no uso do solo. Observa-se uma diminuição progressiva das áreas destinadas a agricultura (lavoura permanente), na maioria dos municípios, com alguns apresentando drásticas reduções a partir das últimas décadas.

VALÊNCIO et al.(1999), aponta para diferenças em termos de volume e opções agrícolas, já que após o início do funcionamento do reservatório de Barra Bonita houve uma maior tendência ao uso de lavouras temporárias, entrando as permanentes em declínio irreversível, principalmente após 1980. Tal tendência anuncia uma ocupação diferenciada do território, mais pelo aspecto intensivo do que extensivo da ocupação. 
Desta forma, a agricultura na região perdeu em espaço aquilo que foi possível ganhar em termos de suporte tecnológico.

\section{CONCLUSÕES}

A análise quantitativa e qualitativa de metais nos sedimentos dos principais compartimentos iniciais do Reservatório de Barra Bonita, assim como as avaliações dos processos de uso e ocupação dos solos na região, após o fechamento da barragem, permitem concluir que:

- A implantação do reservatório de Barra Bonita implicou em transformações de ordem social e ambiental, nos municípios do Médio Tietê Superior e da bacia do Piracicaba. Com a modernização da agricultura intensificaram-se os índices de êxodo rural, transformando o cenário urbano dos municípios. Além disso, houve melhoria considerável na malha rodoviária da região, contribuindo para a instalação e desenvolvimento de grandes pólos industriais;

- A entrada de dejetos de esgotos e indústrias, acrescidos da própria produtividade do sistema, confere aos depósitos de sedimento altos teores de matéria orgânica, caracterizando a maioria das amostras como sedimento orgânico;

- O rio Tietê é o compartimento mais intensamente impactado, com altas concentrações de metais. Verificou-se poluição evidente por $\mathrm{Mn}, \mathrm{Cd}, \mathrm{Pb}$ e Ni. Este compartimento está inserido em uma região de alta influência antrópica, recebendo efluentes da região da Grande São Paulo, que engloba o maior parque industrial da América Latina e apresenta uma rede urbana extensa e desordenada. O rio Piracicaba apresentou poluição moderada por $\mathrm{Mn}$ e $\mathrm{Pb}$;

- A região de confluência apresentou-se apenas poluída por $\mathrm{Pb}$. Apesar de receber as cargas poluidoras do rio Piracicaba e Tietê, os impactos gerados neste local não são de alta magnitude, o que pode ser decorrente de processos deposicionais a montante, com minimização dos impactos nesta região; 
- Os sedimentos dos principais compartimentos iniciais do Reservatório de Barra Bonita apresentaram altas frações de metais potencialmente biodisponíveis, muitas vezes chegando a $100 \%$ de disponibilidade. Além da influência da granulometria, ressalta-se as inúmeras variáveis que podem regular os processos de adsorção/ desorção de metais em sedimentos, conferindo a estes ambientes uma característica dinâmica e complexa, em termos de acumulação de metais;

- A magnitude das influências antropogênicas na área de influência do Reservatório de Barra Bonita provoca alterações de cunho deposicional, que implica na impossibilidade de estudos cronológicos em locais com estas características. O perfil de sedimento mais estável em termos de sedimentação obteve idade média de 25 anos, a $50 \mathrm{~cm}$ de profundidade e apresentou relações entre a tendência de aumento das concentrações de cobre ao longo dos anos e atividade relacionadas, como o uso de algicidas (sulfato de cobre) e o crescimento industrial pronunciado, a partir da década de 70 . 


\section{REFERÊNCIAS BIBLIOGRÁFICAS}

CAZOTTI, R. I. (2002). Datação de sedimentos lacustres com ${ }^{210} \mathrm{~Pb}$ : metodologia e aplicações nas barragens do rio Tietê. São Carlos. Tese (doutorado) Departamento de Química- UFScar.

COSTA, J. B (2001). Avaliação ecotoxicológica da água e sedimento de tributários do reservatório de Barra Bonita (Médio Tietê Superior-SP). São Carlos. Dissertação (mestrado) EESC/USP, 281.

DIN, Z. B. (1992). Use of aluminium to normalise heavy metal data from estuarine and coastal sediments of straits of Melaska. Marine Poll.Bull., (24),10,484-491.

DORNFELD, C. B; MASSUTI, M. B.; SILVÉRIO, P. F.; ALMEIDA, C. A. (2002). Caracterização ecotoxicológica do sedimento da Represa do Lobo (ItirapinaBrotas, SP) e seus tributários. In: Recursos hidroenergéticos:usos, impactos e planejamento integrado. v 1.Editora:Rima, São Carlos p.75-90.

ESPÍNDOLA, E. L. G; PASCHOAL, C. M. R. B; TONISSI, F. B; MAGALHÃES, R. (1998). Avaliação ecotoxicológica de sedimento como instrumento de controle de qualidade de água do Reservatório de Salto Grande, Americana, SP. simpósio de ecossistemas brasileiros. Águas de Lindóia,SP. Anais v.4, p.99-111.

ESTEVES, F.A; FERREIRA, J. R; PESSENDA, L. C. R; MORTATTI, J.(1981). Análises preliminares sobre o teor e a distribuição de metais em sedimentos de represas do estado de São Paulo. Simpósio Regional de Ecologia,2 UFScar, São Carlos,SP. Anais p.323-342.

ESTEVES, F.A. (1998). Fundamentos da limnologia. 2ed Rio de janeiro:Interciência, $602 \mathrm{p}$.

FUNDAÇÃO INSTITUTO BRASILEIRO DE GEOGRAFIA E ESTATÍSTICA (1960, 1970, 1980, 1991, 2000). Censos demográficos. Rio de Janeiro, IBGE. 
FUNDAÇÃO INSTITUTO BRASILEIRO DE GEOGRAFIA E ESTATÍSTICA (1960, 1970, 1980). Censos do comércio e indústria. Rio de Janeiro, IBGE.

FUNDAÇÃO INSTITUTO BRASILEIRO DE GEOGRAFIA E ESTATÍSTICA (1960, 1970, 1980, 1991, 2000). Censos agropécuários. Rio de Janeiro, IBGE.

KRUG, F. J. (1996). Pré-tratamento de amostras. I workshop on methods of sample decomposition. CENA. Piracicaba. 108p.

LEGENDRE, L. (1983). Measures of ecological resemblance. In: Numerical Ecology: Developments in Environmental Modelling. E. Scientific Publishing Company, $317 \mathrm{p}$.

LEITE, M. A.(2002). Análise do aporte, taxa de sedimentação e da concentração de metais na água, plâncton e sedimento do Reservatório de Salto Grande, Americana-SP. São Carlos (tese) doutorado EESC/USP 196p.

MACIAS-ZAMORA, J.V; VILLAESCUSA-CELAYA, A; MUNOZ-BARBOSA, A. (1999). Environmental Polluition. V.104. p.69-77.

MARCIANO, F.T. (2001). Estudo limnológico da bacia do rio Sorocaba (SP) e utilização do índice de integridade biótica da comunidade de peixes para a avaliação ambiental. São Carlos (dissertação) mestrado EESC/USP, 89p.

MASUTTI, M. B.(1999). O manguezal do Itacorubi como barreira biogeoquímica: estudo de caso. Florianópolis (dissertação) mestrado UFSC, 196p.

MOORE, J; RAMAMOORTHY, S (1984) Heavy metals in natural waters: Applied Monitoring and Impact Assessment 1ed Springer- Verlog, NY. 
MOZETO, A. A (2001). Workshop de avaliação do projeto qualised: bases técnicocientíficas para o desenvolvimento de critérios de qualidade de sedimentosexperimentos de campo e laboratório. São Carlos:UFSCAR 69p.

NASCIMENTO, M.; MOZETO, A. A. (2001). Valores de Referência para Metais Pesados e Contaminação em Sedimentos Fluviais e Lacustres na Bacia do Rio Tietê. In: Workshop de avaliação projeto Qualised. São Carlos. UFScar.

RODGHER, S; ESPÍNDOLA,E. L G; FRACÁSIO, R; RODRIGUES, M. H; PEREIRA, R. H. G; ROCHA, O.(2002). Estudos ecotoxicológicos nos reservatórios em cascata do Médio e Baixo rio Tietê: uma avaliação dos impactos ambientais. In: Recursos hidroenergéticos: usos, impactos e planejamento integrado. v 1.Editora:Rima, São Carlos p.75-90.

SEMA (1984). Relatório de qualidade do meio ambiente. Brasília. 276p.

SILVÉRIO, P. F. (1999). Partição, biodisponibilidade e toxicidade de metais pesados a organismos bentônicos em sedimentos. Dissertação (mestrado) .UFScar 78 p.

THOMAS, R. L. (1987). A protocol for the selection of process-oriented remedial options to control in situ sediment contaminants. Hidrobiol v.149, Ecological effects of in situ sediment contaminants. p.43-51

TONISSI, F. B (1998). Avaliação ecotoxicológica do reservatório de Salto Grande, Americana (SP) como subsídio para a análise da qualidade ambiental do sistema. São Carlos (dissertação) mestrado EESC/USP, 137p. 
VALÊNCIO, N. F. L. S; GONÇALVES, J C; VIDAL, K. C; MARTINS, R. C;

RIGOLIN, M. V; LOURENÇO, L. C; MENDONÇA, S. A.T.; LEME, A. A. (1999).

O papel das hidroelétricas no processo de interiorização paulista: o caso das usinas hidroelétricas de Barra Bonia e Jurumirim. In: HENRY,R. Ecologia de reservatórios: estrutura, função e aspectos sociais. Botucatu: FUNDBIO:FAPESP, $626 p$.

WEBER, M. (1967). A ética protestante e o espírito do capitalismo. São Paulo, Pioneira. 217p. 


\title{
Capítulo 3
}

\author{
"Estoque de nutrientes (nitrogênio e fósforo total) nos sedimentos dos rios Tietê e \\ Piracicaba, nos seus compartimentos de entrada no Reservatório de Barra Bonita- \\ SP"
}

\section{INTRODUÇÃO}

Os sedimentos desempenham importante papel nos ecossistemas aquáticos uma vez que podem se constituir em depósito para muitos contaminantes, em especial para os metais traço, a matéria orgânica e os nutrientes. A deposição de sedimentos lacustres depende de diversos fatores ambientais (origem da bacia, tamanho e profundidade do lago, relevo, cobertura vegetal da área de drenagem, entre outros). Tais fatores influenciam a composição química dos sedimentos, refletindo na concentração de nutrientes e, consequentemente na vida do lago, considerando as intensas trocas que ocorrem entre os sedimentos e a coluna de água. ( DORNFELD et al., 2002).

A simples conversão de um sistema lótico para lêntico provoca aumento do processo de eutrofização, pois ao reduzir a velocidade da água ocorre aumento na acumulação de nutrientes. O aumento da disponibilidade de nutrientes na coluna de água, dá inicio a uma intensa colonização por macrófitas. Esta colonização tende a diminuir após a estabilidade alcançada pelo sistema (adsorção pelos sedimentos e deposição dos nutrientes no fundo do lago, entre outros), no entanto há a manutenção da mesma. Considerando-se ainda as entradas de nutrientes através das atividades realizadas na bacia de entorno do reservatório pode-se afirmar que existe forte incremento no processo de eutrofização, além do contingente estocado nos sedimentos.

O fenômeno da erosão muito contribui para a perda de nitrogênio do solo, no entanto as estimativas não são muito precisas. A destruição de florestas e terras alagadas 
libera um grande volume de nitrogênio adicional, que havia sido seqüestrado em vegetais e solos. No mundo, as atividades humanas devem ter no mínimo duplicado a liberação de nitrogênio fixxo para 350 milhões de toneladas anuais (e esta cifra não inclui mudanças na parte marinha do ciclo do nitrogênio) (BRIGHT,2003).

O Reservatório de Barra Bonita encontra-se inserido em uma região altamente desenvolvida, sendo alvo de inúmeras interferências antrópicas. Estima-se que a carga diária de DBO gerada nas áreas urbanas da região através de efluentes seja de aproximadamente 137 toneladas, das quais somente 7,5 toneladas recebem tratamento (SEMA (1999) apud COSTA (2001)). Considerando-se o acelerado desenvolvimento da região, principalmente notório em termos de crescimento demográfico, estima-se que haja consequentemente um aumento na produção de efluentes gerados na bacia.

Segundo CALIJURI \& TUNDISI (1990), todos os estudos realizados neste reservatório ressaltam a alta carga orgânica dos aportes e a conseqüente liberação de nutrientes, o que tem conduzido a um acelerado processo de eutrofização, com grandes blooms de cianofícias e proliferação de macrófitas. BOTTA-PASCHOAL (2002), ao caracterizar os sedimentos recentes do rio Piracicaba e Tietê verificou altas cargas de nutrientes associados aos mesmos.

De acordo com o exposto, torna-se evidente a importância do estudo dos estoques de nutrientes nas camadas sedimentares, que podem em determinadas condições contribuir expressivamente com os processos ecológicos desenvolvidos na coluna da água. Assim, cabe ainda considerar a magnitude da influência antropogênica na bacia hidrográfica, a fim de apresentar um cenário mais completo e integrado da situação do sistema analisado. 


\section{OBJETIVOS}

Determinar as concentrações de nitrogênio orgânico total e fósforo total em perfis de sedimentos dos principais compartimentos iniciais do reservatório de Barra Bonita (rio Piracicaba e rio Tietê), e avaliar a distribuição das concentrações ao longo das camadas sedimentares, indicando as possíveis fontes de entrada de nutrientes no sistema através da análise da tendência de desenvolvimento urbano da bacia nos últimos 40 anos.

\section{METODOLOGIA}

\subsection{EM CAMPO:}

As coletas foram realizadas em novembro de 2002, sendo as estações de coleta determinadas através de mapas topográficos, abrangendo áreas localizadas ao longo de cada tributário até a região do encontro de ambos. O Anexo 01 apresenta a localização do Reservatório de Barra Bonita, seus principais tributários e as estações de coleta e o Anexo 02 apresenta as coordenadas geográficas de cada estação de coleta:

As estações de coleta foram georreferenciadas com o uso do GPS Trimble Navigator, sendo estas coincidentes com estações já utilizadas em estudos anteriores e em andamento no Núcleo de Estudos de Ecossistemas Aquáticos (NEEA), do Centro de Recursos Hídricos e Ecologia Aplicada, da EESC/USP.

As amostras de sedimento foram coletadas com o auxílio do "Core Sampling”, que possibilita a manutenção da deposição original das camadas sedimentares. Os testemunhos coletados foram fracionados em sub-amostras de $10 \mathrm{~cm}$ e acondicionadas em recipientes plásticos, conservadas em caixa térmica adequados ao transporte até o laboratório. 


\subsection{EM LABORATÓRIO}

As amostras de sedimento foram expostas ao ambiente para evaporação da água e então permaneceram em estufa a $40^{\circ} \mathrm{C}$ por 24 horas para secagem completa. Após estes procedimentos iniciais as amostras foram pulverizadas em almofariz, e separadas para a realização das seguintes análises:

- Nitrogênio Orgânico Total

A determinação da concentração de nitrogênio orgânico em cada sub-amostra foi realizada pelo método de Kjedhal, segundo a metodologia descrita em GOLTERMAM et al., (1978).

\section{- Fósforo Total}

A concentração de fósforo total em cada sub-amostra foi determinada seguindo a metodologia apresentada por ANDERSEN (1976). 


\section{RESULTADOS E DISCUSSÕES}

\subsection{NITROGÊNIO TOTAL}

Na Figura 21 são apresentados os percentuais de nitrogênio orgânico total obtidos em cada sub-amostra em todas as estações de coleta. Verifica-se um padrão de distribuição similar, com tendência ao acréscimo dos percentuais no sentido das camadas mais profundas à superfície em todas as estações, exceto na estação 3 (rio Piracicaba).

O maior valor observado foi de $0,75 \%$ na camada de $10 \mathrm{~cm}$ da estação 5 (rio Tietê), e o menor valor obtido foi de $0,04 \%$, na camada de70 $\mathrm{cm}$, da estação 6 (rio Tietê). Deve-se considerar neste caso a posição da estação 5 , já que se encontra na região de desembocadura do Braço Capivara (rio Capivara e Lavapés), os quais contribuem diretamente com o aporte de nutrientes nesta estação. LEITE (2002) encontrou valores inferiores no Reservatório de Salto Grande, onde o maior valor foi de $0,28 \%$ de nitrogênio nas camadas mais recente de deposição. PATELLA (1998) também obteve os maiores valores nas camadas recentes de deposição, com $0,9 \%$ de nitrogênio na camada $0-2 \mathrm{~cm}$, nos sedimentos da represa de Guarapiranga.

Existe uma forte tendência ao acréscimo dos valores de nitrogênio nas camadas recentes de deposição na maioria dos reservatórios do Estado de São Paulo o que, entre outros fatores, reforça a influência dos grandes centros urbanos sobre a qualidade dos recursos hídricos. O nitrogênio de origem alóctone é fornecido principalmente através de despejos principalmente domésticos (a maior parte sem tratamento), no entanto existe contribuição contínua deste elemento dentro do próprio sistema, podendo-se citar como uma das fontes a proliferação intensa de macrófitas observada na área de estudo. 
A estação 3 apresentou padrão inverso aos demais, com uma diminuição pronunciada no sentido da camada superficial de sedimento. Deve-se ressaltar, neste caso, que o número de sub-amostras obtidas talvez não seja suficiente para uma conclusão tão linear. No entanto, no contexto geral da análise, pode-se considerar os sedimentos dos compartimentos analisados ricos em nitrogênio.

Comparando-se as médias obtidas em cada tributário (a partir das camadas mais recentes, que poderão efetivamente contribuir com o aporte à coluna de água), verificase o valor médio de $0,26 \%$ no rio Piracicaba e $0,54 \%$ no rio Tietê. O valor encontrado no rio Tietê é duas vezes maior em relação ao rio Piracicaba. Esta heterogeneidade é típica de reservatórios com o padrão morfométrico do tipo dendrítico, como é o caso do Reservatório de Barra Bonita, já que cada compartimento pode apresentar comportamentos distintos. Acredita-se que o rio Piracicaba esteja sendo beneficiado em termos de qualidade ambiental pela presença do reservatório de Salto Grande localizado a montante. Este reservatório, segundo RIOS (1999), possui alta eficiência de retenção de várias substâncias, servindo desta forma como um grande sistema de tratamento ou retenção de poluentes, com reflexo direto na qualidade ambiental do rio Piracicaba. Evidentemente que, considerando o fato do rio Tietê receber praticamente todo o efluente gerado na região metropolitana de São Paulo e por estar localizado em uma região extremamente desenvolvida (urbanização, industrialização), pode-se considerar que o padrão encontrado seja explicado, principalmente, por tais razões. 

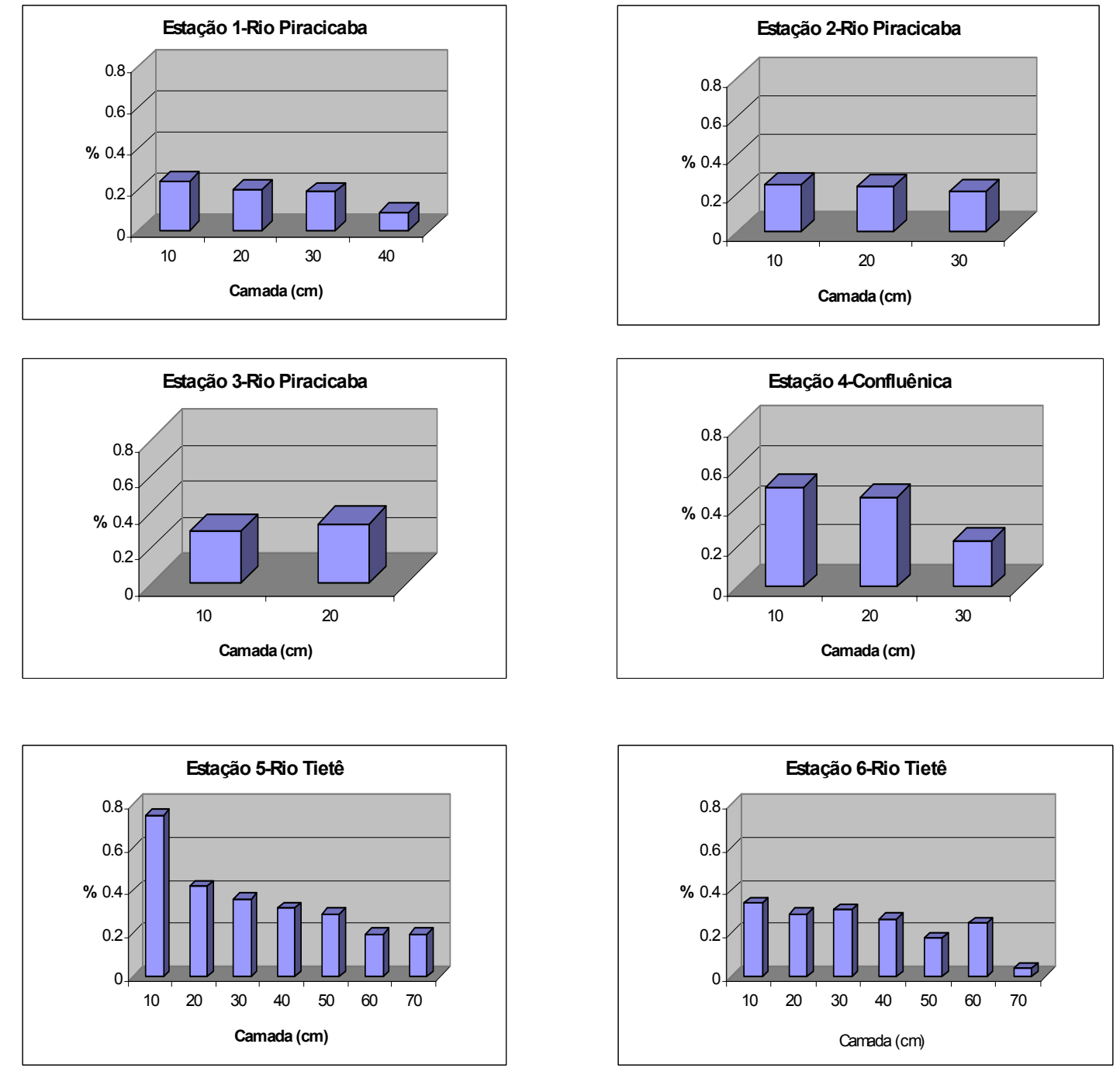

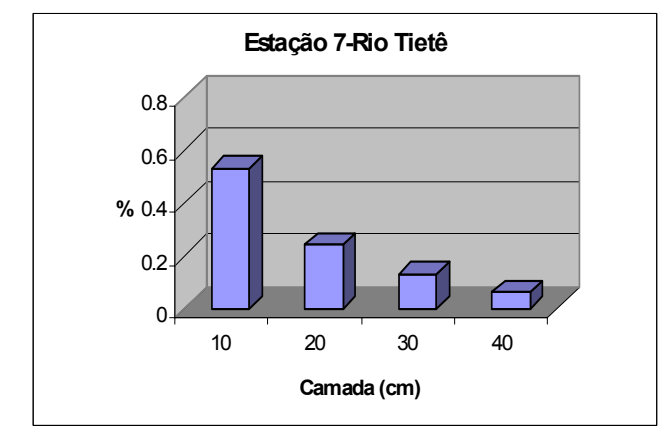

Figura 21: Concentração de nitrogênio total no perfil dos sedimentos dos compartimentos iniciais do Reservatório de Barra Bonita (rio Piracicaba e Tietê) 


\subsection{FÓSFORO TOTAL}

Na Figura 22 são apresentados os resultados das concentrações de fósforo total obtidas em cada sub-amostra, nas diferentes estações de coleta. Não se verifica nenhum padrão definido de distribuição vertical das concentrações ao longo do perfil de sedimento, nem tanto distribuição horizontal através das estações de coleta no sentido rio-represa. A menor concentração observada foi de $185 \mu \mathrm{g} \cdot \mathrm{g}^{-1}$ na camada de $30 \mathrm{~cm}$ da estação 2 (rio Piracicaba), a maior concentração foi obtida na camada de $50 \mathrm{~cm}$ da estação 6 (rio Tietê), com $1.206 \mu \mathrm{g} \cdot \mathrm{g}^{-1}$.

LEITE (2002), encontrou concentrações de fósforo na camada de $50 \mathrm{~cm}$ do Reservatório de Salto Grande sempre inferiores a $600 \mu \mathrm{g} \cdot \mathrm{g}^{-1}$. ESTEVES (1988), obteve $513,6 \mu \mathrm{g} \cdot \mathrm{g}^{-1}$ de fósforo no reservatório de Barra Bonita, sendo que no presente estudo a grande maioria das amostras (86\%) apresentou concentrações mais elevadas. Considerando as concentrações obtidas nas camadas recentes $(10 \mathrm{~cm})$ de cada estação, observa-se que o valor médio encontrado no rio Tietê é de $1092,7 \mu \mathrm{g}^{-g^{-1}}$ de fósforo, elevado em relação a média obtida para o rio Piracicaba, $743 \mu \mathrm{g} \cdot \mathrm{g}^{-1}$. CARMO (2000), analisando as concentrações de fósforo em sedimentos do Lago das Garças-SP, encontrou o valor máximo de $1673 \mu \mathrm{g} \cdot \mathrm{g}^{-1}$ em uma área que sofre o efeito da entrada de efluentes não tratados, principalmente os dejetos dos animais confinados no Zoológico de São Paulo.

Ressalta-se que, da mesma forma que a biomassa de macróficas pode atuar no incremento de nitrogênio ao sistema, o fósforo é continuamente incorporado a água e sedimento através do ciclo natural destas plantas, representando fonte autóctone de nutrientes, sendo que o reservatório de Barra Bonita, classificado como eutrófico, apresenta extensos bancos de macrófitas e blooms de algas, inclusive próximos ao local de estudo.

No entanto, as altas concentrações de fósforo total encontradas nos perfis sedimentares indicam entradas principalmente de origem alóctone, principalmente se analisadas as margens do reservatório, preferencialmente cultivadas com monocultura de cana-de-açúcar, e a própria área de drenagem das bacias em questão (intenso desenvolvimento urbano e industrial). As variações encontradas na distribuição vertical e horizontal das concentrações de fósforo podem ser discutidas com base em TUNDISI 
(1996), que aponta esta heterogeneidade com relação aos nutrientes como um reflexo das fontes não pontuais de poluição proveniente da bacia hidrográfica.
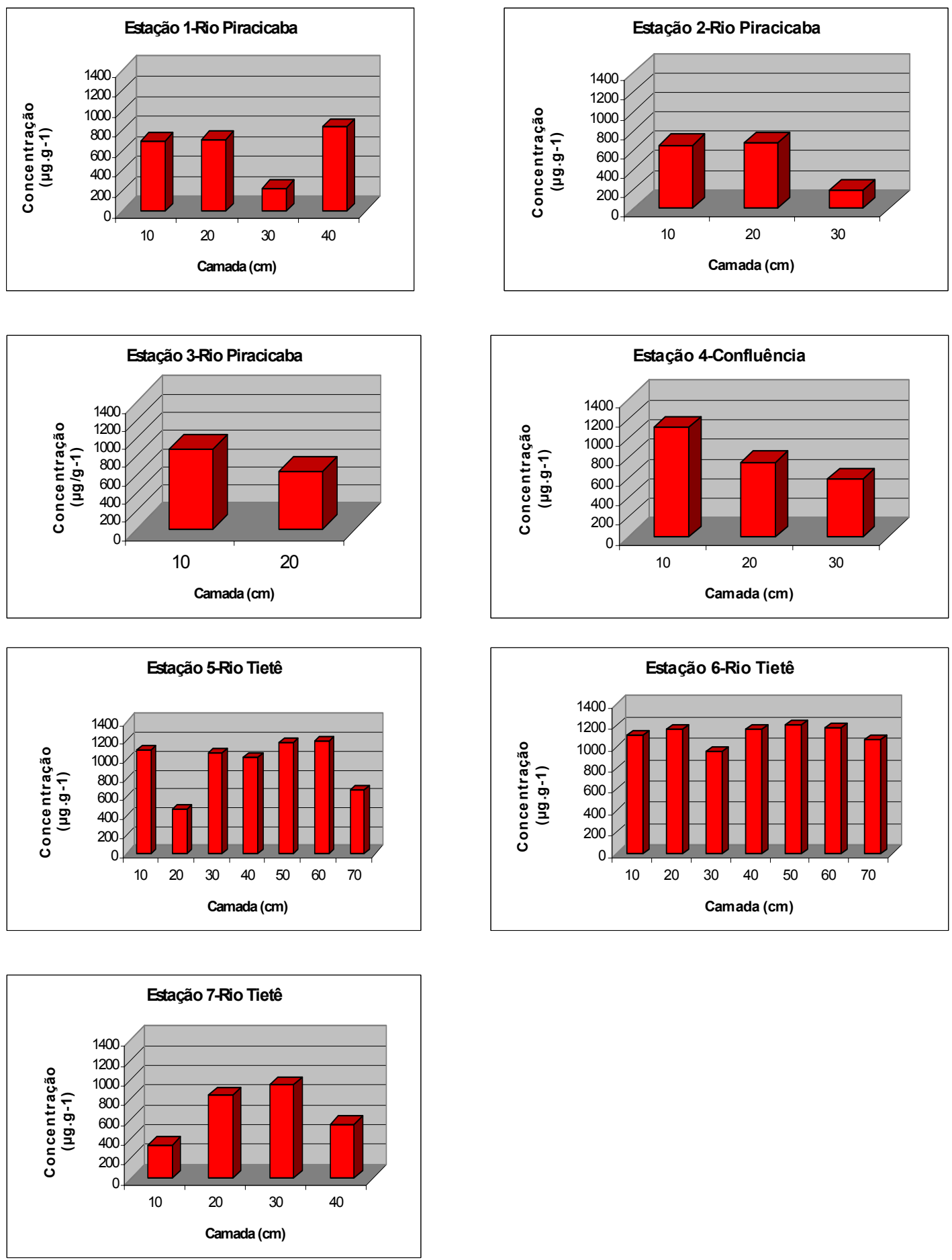

Figura 22: Concentração de fósforo total no perfil dos sedimentos dos compartimentos iniciais do Reservatório de Barra Bonita (rio Piracicaba e Tietê) 


\subsection{CRESCIMENTO URBANO AO LONGO DO RIO PIRACICABA, RIO TIETÊ E SEUS TRIBUTÁRIOS A PARTIR DA DÉCADA DE 60.}

A bacia hidrográfica do rio Piracicaba e Médio Tietê Superior são caracterizadas pela elevada concentração urbana e industrial. COSTA (2001) aponta que o estágio de degradação ambiental deste sistema ocorre em função da intensidade das atividades humanas realizadas na bacia de drenagem, pois detectou, através do estudo da qualidade da água e sedimentos de vários tributários que afluem direta ou indiretamente no reservatório de Barra Bonita, uma variação espacial dos níveis de impacto ambiental com contaminação pronunciada dos rios inseridos em regiões portadoras de grandes núcleos urbanos e pólos industriais. As fontes pontuais de poluição são representadas principalmente por despejos domésticos e industriais, e representam a principal fonte de contaminação dos recursos hídricos. Como secundária, porém não menos importante, está a poluição não pontual, representada por escoamentos condicionados pela precipitação nas áreas urbanas e rurais.

O rio Piracicaba recebe efluentes, a grande maioria sem tratamento adequado, de cidades com elevados níveis de desenvolvimento urbano, citando-se as cidades de Piracicaba, Limeira, Rio Claro e Americana. Os efluentes destas cidades alcançam as águas do rio Piracicaba, e juntamente com os efluentes dos demais pólos urbanos, contribuem de forma muito significativa com processo de eutrofização no Reservatório de Barra Bonita.

$\mathrm{O}$ rio Tietê, além de receber cargas de poluentes de diversas cidades com alto índice de desenvolvimento, como Barueri, Botucatu e Jundiaí, ainda é acrescido dos despejos da Grande São Paulo.

Segundo MONTICELI \& MARTINS (1993), a composição média dos efluentes domésticos é mais ou menos constante, diferentemente dos resíduos industriais e agrícolas, que são mais variáveis. O esgoto contém sólidos sedimentáveis, que se depositam no fundo dos ambientes aquáticos prejudicando, entre outros, o habitat natural de filhotes de peixes.

No presente estudo foram realizados levantamentos de censos demográficos do IBGE, a partir de 1960 (início do represamento dos rios Piracicaba e Tietê), das cidades mencionadas anteriormente. Na região da Grande São Paulo foram selecionadas as 
cidades de Osasco, Suzano e Mogi das Cruzes. Ressalta-se que as cidades discutidas no presente estudo foram selecionadas sem um critério pré-estabelecido, com a intenção de fornecer um panorama, em termos gerais, do intenso processo de desenvolvimento atuantes na bacia.

\subsubsection{BACIA DO RIO PIRACICABA}

No Anexo 03 A apresenta-se o número de habitantes obtidos a partir das campanhas realizadas pelo IBGE, a partir de 1960, com o número total de habitantes e população urbana e rural, das cidades selecionadas na bacia do rio Piracicaba.

Verifica-se, de forma geral, a tendência ao crescimento populacional nas áreas urbanas e diminuição contínua da população rural, ao longo dos anos. Padrões similares de abandono do campo rumo à cidade são observados em todo o país, visto que nas últimas décadas as áreas urbanas atraem as pessoas em busca de melhores condições de vida do que aquela oferecida na zona rural. A própria construção de reservatórios atrai significativo contingente populacional para a região em que é implantado. Segundo PRADO (2002), o caso do Reservatório de Barra Bonita não foi diferente, pois observase que após sua construção em 1963, ocorreu a implementação de diversas novas atividades, como as pesqueiras, industriais e turísticas. HENRY (1999), contatou que a análise histórica do processo de ocupação no entorno de reservatórios permite observar que os interesses econômicos acabam se sobrepondo aos interesses locais.

Estima-se que na bacia do rio Piracicaba $50 \%$ da DBO produzida diariamente é devida ao lançamento de esgotos domésticos sem tratamento, proveniente das cidades da região ( MONTICELI \& MARTINS, 1993)

Verifica-se que o número total de habitantes na cidade de Americana praticamente duplicou a cada década, sendo que atualmente 99,8\% dos habitantes concentram-se na área urbana. No caso de Piracicaba o crescimento populacional deu-se de forma mais contínua. No entanto, ao analisar o contingente rural constata-se que atualmente está reduzido a 1/3 do número de habitantes existentes na zona rural em 1960. Atualmente 94,4\% da população concentram-se na área urbana de Piracicaba. A cidade de Rio Claro não apresenta um padrão tão pronunciado de diminuição de população rural, embora atualmente apresente $97,2 \%$ da população vivendo em área urbana. No caso de Limeira, existe grande oscilação no contingente rural. No Anexo 3 E verifica-se que as áreas das 
propriedades agrícolas (ha) não diminuíram progressivamente ao longo dos anos, como nos demais casos. Apesar de $95,7 \%$ da população estar concentrada na área urbana de Limeira, esta apresenta a maior área ocupada por propriedades rurais (32000 hectares), em relação às cidades abordadas.

\subsubsection{BACIA DO MÉDIO TIETÊ SUPERIOR E REGIÃO DA GRANDE SÃO PAULO}

No Anexo 03 B apresenta-se o número de habitantes obtidos a partir das campanhas realizadas pelo IBGE, a partir de 1960, com o número total de habitantes e população urbana e rural, das cidades selecionadas na bacia do Médio Tietê Superior e cidades da Grande São Paulo.

Verifica-se padrão similar ao encontrado na bacia do rio Piracicaba, com alta concentração de habitantes em áreas urbanas e diminuição da população rural ao longo dos anos. Ressalta-se que a década de 90 apresentou a maior taxa de crescimento populacional em todas as cidades analisadas, sendo a cidade de Barueri o caso mais notório de desenvolvimento, com a população passando de 30.319 habitantes em 1980 para 177.256 habitantes em 1990. A cidade de Jundiaí apresenta 92,8\% da população habitando a área urbana, em Barueri esta cifra corresponde a 100\% e em Botucatu $96,02 \%$.

Nas cidades da Grande São Paulo verifica-se a mesma tendência, com diminuição da população rural e das áreas ocupadas por agricultura. Atualmente, as cidades de Osasco (100\% população urbana) e Suzano (96,8\% população urbana) não apresentam área ocupada por agricultura. No entanto, a população rural registrada em Suzano possivelmente pratica agricultura de subsistência ou trabalha em outras regiões. Mogi das Cruzes apresenta o menor índice, 91,5\%, de população urbana, e maior área ocupada por agricultura até 1990 (41.541 hectares), reduzindo-se drasticamente no último levantamento realizado em 2000 (1.143 hectares). Isto indica um crescente processo de urbanização, presente também nas demais cidades analisadas. 


\section{CONCLUSÕES}

O estudo das concentrações de nutrientes nas camadas sedimentares dos principais compartimentos iniciais do reservatório de Barra Bonita, e suas relações com a tendência de desenvolvimento urbano na bacia, permite concluir que:

- As concentrações de nitrogênio orgânico total, principalmente nas camadas superficiais ou recentes de deposição, são altas. Existe uma evidente tendência ao aumento das concentrações ao longo do perfil, em sentido à superfície, podendo representar as entradas pontuais através dos despejos de efluentes das áreas de entorno;

- A tendência de distribuição de nitrogênio orgânico total ao longo dos perfis de sedimento corrobora com a tendência do crescimento demográfico em alguns municípios da região, a partir da década de 60 (início do funcionamento do reservatório);

- O rio Piracicaba apresenta concentrações de nitrogênio total menos elevadas, em relação às concentrações obtidas no rio Tietê. O rio Tietê além de receber uma carga considerável de efluentes da região metropolitana de São Paulo, ainda tem seus impactos agravados por atravessar regiões extremamente populosas e desenvolvidas (Barueri, Jundiaí, entre outras).

- As concentrações de fósforo total aumentaram nos últimos 15 anos, condicionado pelas fontes pontuais de entrada bem como pelos processos intrínsecos do sistema (por exemplo, a biomassa de macrófitas e algas cianofícias);

- O rio Piracicaba apresenta concentrações de fósforo total menos elevadas em relação ao rio Tietê. Além da minimização dos impactos no rio Piracicaba, em virtude do Reservatório de Salto Grande, deve-se considerar a magnitude das fontes de entrada de nutrientes no rio Tietê;

- O intenso crescimento urbano representa a principal fonte pontual de nutrientes que aportam ao reservatório de Barra Bonita, e pode ser considerado o principal responsável pela contaminação deste sistema. 


\section{REFERÊNCIAS BIBLIOGRÁFICAS}

ANDERSEN, J. M. (1976). An ignition method for determination of total phosforus in lake sediments. Wat.Res., v.10, p.329-331.

BOTTA-PASCHOAL, C. M. R. (2002). Avaliação ecotoxicológica de sedimentos em reservatórios da bacia do rio Tietê,SP, com ênfase na aplicação do estudo de AITAvaliação e identificação da toxicidade. São Carlos (tese) Doutorado EESC/USP, $146 \mathrm{p}$.

BRIGHT,C (2003). Estado do Mundo: a impossível revolução ambiental está acontecendo. Salvador: WWI-UMA Ed. 226p.

CALIJURI, M. \& TUNDISI, J. G. (1990). Limnologia comparada das represas do Lobo (Broa) e Barra Bonita- Estado de São Paulo: Mecanismos de funcionamento e bases para o gerenciamento. Rev. Brasil. Biol. 50 (4):839-913.

CARMO, C. F. (2000). Aporte de nutrientes, nitrogênio e fósforo, e sua relação com os impactos antropogênicos em um lago urbano, São Paulo, SP ,Brasil. São Carlos (dissertação) mestrado EESC/USP, 138p.

COSTA, J. B (2001). Avaliação ecotoxicológica da água e sedimento de tributarios do reservatório de Barra Bonita (Médio Tietê Superior-SP). São Carlos (dissertação) mestrado EESC/USP, 281.

DORNFELD, C. B; MASSUTI, M. B.; SILVÉRIO, P. F.; ALMEIDA, C. A. (2002). Caracterização ecotoxicológica do sedimento da Represa do Lobo (ItirapinaBrotas, SP) e seus tributários. In: Recursos hidroenergéticos:usos, impactos e planejamento integrado. v 1.Editora:Rima, São Carlos p.75-90.

FRACÁCIO, R.; ESPÏNDOLA, E. L. G.; RODGHER, S.; PEREIRA, R. H. G.; ROCHA, O; VERANI, N. F. (2002). Limnologia dos reservatórios em cascata do Médio e Baixo Rio Tietê: uma análise espacial e temporal. In: Recursos 
hidroenergéticos: usos, impactos e planejamento integrado. v 1.Editora:Rima, São Carlos p.145- 163.

GOLTERMAN, H. L. et al (1978). Methods for physical and chemical analisys of fresh waters. 2 ed. Oxford, Blackweel Scientific Publications.

HENRY, R. (1999). Ecologia de reservatórios: estrutura, função e aspectos sociais. Rio Claro, Departamento de Zoologia, Instituto de Biociências, Unesp. 799p

FUNDAÇÃO INSTITUTO BRASILEIRO DE GEOGRAFIA E ESTATÍSTICA (1960, 1970, 1980, 1991, 2000). Censos demográficos. Rio de Janeiro, IBGE.

LEITE, M.A.(2002). Análise do aporte, taxa de sedimentação e da concentração de metais na água, plâncton e sedimento do Reservatório de Salto Grande, Americana-SP. São Carlos (tese) doutorado EESC/USP 196p.

MONTICELI, J. J; MARTINS, J. P. S. (1993). A luta pela água- Nas bacias dos rios Piracicaba e Capivarí. Capivarí-SP, Editora:EME 1 ed. 126p.

PATELlA, E (1998). Caracterização biogeoquímica dos estoques de nutrientes de testemunhos de sedimentos e particulados do reservatório de Guarapiranga-SP. Dissertação (mestrado) EESC/USP 65p.

PRADO, R. B. (2002). Manejo integrado de reservatórios destinados a uso múltiplo como perspectiva de recuperação da qualidade da água. In: Recursos hidroenergéticos: usos, impactos e planejamento integrado. v 1.Editora:Rima, São Carlos p.193-208.

RIOS, L (1999). Distribuição espaço-temporal e balanço de massa do fósforo na represa de Salto Grande-Americana (SP). São Carlos Tese (doutorado) EESC/USP. 159p.

TUNDISI. J. G. (1996). Reservoir as complex systems. Ciên. E Cul., v.48, n.5/6, p.383387. 
VON SPERLING, M. (1996). Princípios do tratamento biológico de águas residuárias: Introdução a qualidade das águas e ao tratamento de esgotos.2ed. Belo Horizonte, Departamento de engenharia sanitária e ambiental: UFMG. 


\section{Capítulo 4}

\section{"Avaliação ecotoxicológica dos sedimentos dos rios Tietê e Piracicaba, nos seus compartimentos de entrada no Reservatório de Barra Bonita - SP. "}

\section{INTRODUÇÃO}

A toxicologia ambiental e a ecotoxicologia são termos empregados para descrever o estudo científico dos efeitos adversos causados sobre os organismos vivos pelas substâncias químicas liberadas no ambiente. A expressão Toxicologia Ambiental é utilizada, geralmente, nos estudos que abordam os efeitos das substância químicas sobre os seres humanos, enquanto Ecotoxicologia é o termo empregado em estudos que tratam dos efeitos destas substâncias sobre os ecossistemas e seus componentes não humanos (FERNICOLA et al.,2003)

O princípio fundamental da ecotoxicologia é baseado na análise dos processos de transferência de contaminantes nos ecossistemas e nos efeitos sobre sua estrutura e funcionamento (BOUDOU \& RIBERYRE, 1989 apud FERNICOLA et al., 2003)

Os testes de toxicidade podem apresentar efeitos agudos ou crônicos, e constituem-se em ensaios nos quais uma quantidade conhecida de organismos é exposta ao agente estressante por períodos conhecidos de tempo e, posteriormente, os efeitos são 
avaliados quanto a sobrevivência ou mortalidade dos organismos, bem como efeitos comportamentais, morfológicos e fisiológicos (RAND \& PETROCELLI,1985).

Segundo CONNEL \& MILLER (1984), os testes mais utilizados em laboratório são os agudos, devido a sua simplicidade e ao curto período de exposição dos organismos ao agente tóxico. Os testes crônicos, também intensamente utilizados, apresentam respostas mais sensíveis ao agente tóxico, sendo realizados durante um período mais prolongado de tempo, podendo expor os organismos ao agente por um determinado período do ciclo de vida da espécie ou por todo seu ciclo.

Os bioensaios com amostras de sedimento podem ser realizados com diferentes frações amostradas, como o sedimento total (fase sólida), elutriato, interface sedimento/água ou água intersticial (COSTA \& ESPÍNDOLA, 2001).

A avaliação da qualidade da água tem tido ao longo dos últimos anos algumas mudanças substanciais do ponto de vista da concepção de programas de monitoramento. Essa mudança de paradigma adota uma nova abordagem que inclui a avaliação da qualidade dos sedimentos, um compartimento que era, até pouco tempo, apenas considerado como um acumulador de nutrientes e contaminantes (MOZETO, 2001).

$\mathrm{O}$ fato de que o ambiente sedimentar pode refletir a qualidade das águas e fornecer habitat para diversos organismos aquáticos, tem difundido amplamente a utilização de testes ecotoxicológicos com sedimentos. Os bioensaios desempenham, desta forma, um importante instrumento de complementação em programas de monitoramento da qualidade da água, gerando informações sobre o perigo potencial dos efeitos de substâncias tóxicas lançadas nos sistemas aquáticos sobre os organismos (GOLDSTEIN et al, 1981).

Os sedimentos contaminados podem ser diretamente tóxicos aos organismos aquáticos ou podem ser uma fonte de contaminantes para o processo de bioacumulação na cadeia trófica, considerando que as mudanças nas características físicas e químicas que ocorrem no ambiente podem disponibilizá-los na coluna d'água, transformando o sedimento numa fonte de contaminantes (DIAS \& MELLO, 1998).

Desta forma, a avaliação da toxicidade dos sedimentos dos principais afluentes do reservatório de Barra Bonita (Rio Piracicaba e o Rio Tietê), vem a contribuir com a investigação da qualidade dos sedimentos destes compartimentos, identificando as áreas mais impactadas do sistema. 


\section{OBJETIVO}

Avaliar a toxicidade dos sedimentos da camada recente de deposição nos principais compartimentos iniciais do reservatório de Barra Bonita (Rios Piracicaba e Tietê), com diferentes frações da amostra e organismos-teste, gerando informações importantes e complementares em relação a qualidade dos sedimentos deste sistema.

\section{METODOLOGIA}

\subsection{AMOSTRAGEM DO SEDIMENTO}

As coletas foram realizadas em novembro de 2002, no Reservatório de Barra Bonita, sendo que as estações de coleta localizam-se ao longo da entrada dos Rios Piracicaba e Tietê. No Anexo 01 encontra-se a localização do Reservatório de Barra Bonita, seus principais tributários e as estações de coleta e no Anexo 02 as coordenadas geográficas de cada estação de coleta

Apenas os sedimentos de recente deposição foram coletados, utilizando-se uma draga de Eckmam. O material foi acondicionado em recipientes plásticos (1Litro), adequados ao transporte, e conservado em caixa térmica a aproximadamente $4^{\circ} \mathrm{C}$.

\subsection{TESTES DE TOXICIDADE}

Os organismos-teste selecionados foram as espécies Chironomus xanthus (Chironomidae, Diptera) e Daphnia similis (Cladocera, Crustacea), cujos exemplares foram obtidos em culturas mantidas no Laboratório de Ecotoxicologia e Ecofisiologia de Organismos Aquáticos, do NEEA/CRHEA/EESC/USP. 
3.2.1 Testes de toxicidade aguda do material solubilizado, a partir da camada recente de sedimento, para o cladócero Daphnia similis (Figura 23)

A solubilização foi realizada com a mistura de sedimento com água destilada numa proporção de 1:4 (sedimento : água), deixando em mesa agitadora por um período de 16 horas, e após a decantação, o sobrenadante foi removido efetuando-se medidas de $\mathrm{pH}$, condutividade e dureza, sendo que em seguida a amostra foi utilizada na efetivação do teste (HILL et al, 1993).

Os testes de toxicidade aguda com solubilizado de sedimento foram realizados conforme os padrões e procedimentos descritos em HILL et al (1993). O organismoteste, Daphnia similis, foi submetido ao material solubilizado, por um período de 48 horas, para a avaliação da letalidade e imobilidade (GOLDSTEIN et al, 1981).

$\mathrm{O}$ teste de toxicidade aguda baseia-se em expor neonatos entre 0 e 24 horas a diversas amostras do material coletado. Os testes foram preparados e realizados em tréplicas utilizando copos descartáveis transparentes com capacidade para $250 \mathrm{~mL}$, contendo $200 \mathrm{~mL}$ da amostra preparada (solubilizado) e 5 organismos-teste. Os organismos em teste permaneceram no escuro por $48 \mathrm{~h}$, em ambiente com temperatura controlada entre $22^{\circ} \pm 2^{\circ} \mathrm{C}$ e sem alimento. Após 48 horas foi efetuada a contagem dos organismos imóveis, ou seja, aqueles que, depois da amostra ser delicadamente agitada e aguardando um período de 15 segundos, não forem capazes de nadar (OLIVEIRA NETO, 2000). O teste é considerado válido se o controle não apresentar imobilidade/letalidade maior que $10 \%$ no total de organismos. 


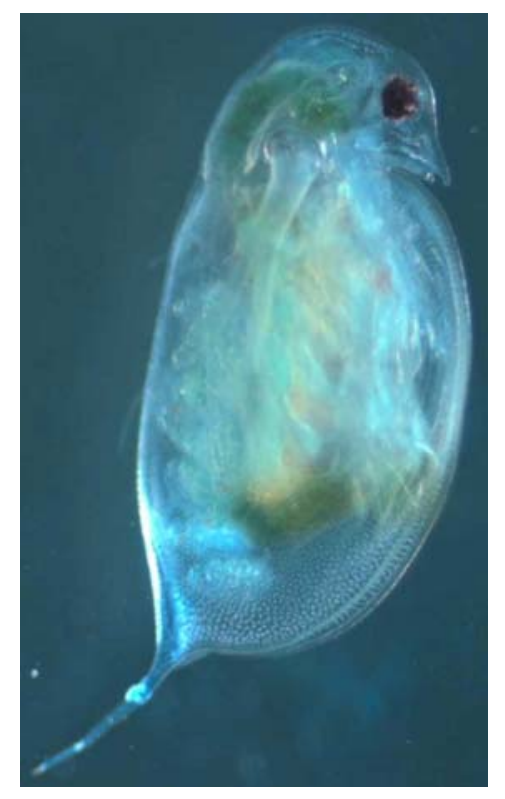

Figura 23: Daphnia similis (2,0- 2,7 mm), (Cladocera, Crustacea)

3.2.2. Teste de toxicidade aguda do sedimento total para o organismo bentônico Chironomus xanthus (Figura 24).

A metodologia de testes agudos utilizada para Chironomus xanthus seguiu a recomendação de FONSECA (1997), utilizando-se a proporção de $1: 4$ sedimento água, respeitando-se o limite de $300 \mathrm{~mL}$ de água por béquer para cada 6 organismos do $3^{\circ}$ ou $4^{\circ}$ instares. Os organismos foram adicionados ao teste somente 24 horas após o preparo dos recipientes, para a sedimentação do material em suspensão. Os testes foram realizados em condições controladas, com temperaturas entre $22^{\circ}$ e $25^{\circ} \mathrm{C}$ e fotoperíodo de 12 horas. A duração do teste foi de 96 horas, sem reposição de água. Após o término do período foram contados os organismos sobreviventes. 


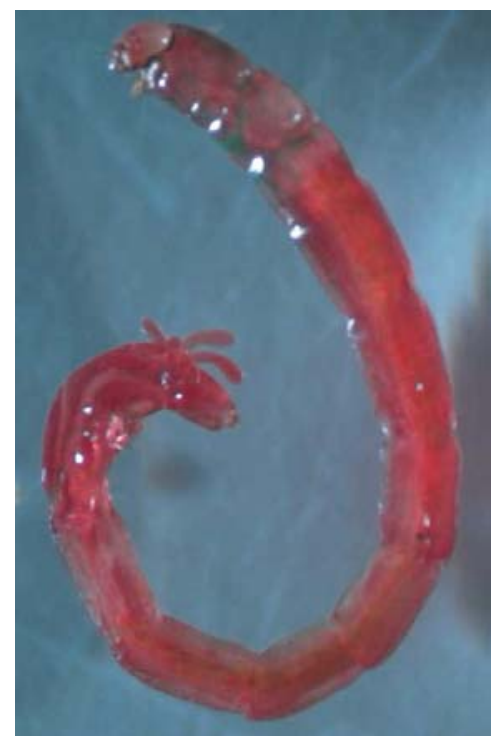

Figura 24: Chironomus xanthus (Chironomidae, Diptera)

\section{RESULTADOS E DISCUSSÕES}

Os testes de toxicidade do solubilizado e do sedimento total foram realizados visando a obtenção da $\mathrm{CL}_{(50)}$, isto é, a concentração em que se observa a mortalidade de $50 \%$ ou mais dos organismos-teste expostos. Neste estudo utilizou-se a $\mathrm{CL}_{(50)}$ para a indicação da estação de coleta com características tóxicas $\left(\mathrm{CL}_{(50)}>50 \%\right)$, indícios de toxicidade $\left(10 \%<\mathrm{CL}_{(50)}<50 \%\right)$ e não tóxicas $\left(\mathrm{CL}_{(50)}>10 \%\right)$. Portanto, os resultados dos testes foram calculados considerando a porcentagem de organismos imóveis em relação aos organismos expostos e a amostra foi considerada tóxica quando a porcentagem de imobilidade atingiu 50\%.

Entre as amostras de sedimentos analisadas, apenas a estação 7 apresentou toxicidade a Daphnia similis. Este estação localiza-se no rio Tietê, no ponto mais distante da região de confluência, ou seja, na região que sofre menos influência do represamento. Neste caso, a mortalidade foi de $100 \%$ dos organismos utilizados no teste, sendo que no controle não houve mortalidade de organismos (Tabela 10). As demais estações, com exceção da estação 5, apresentaram indícios de toxicidade 
Tabela 10 - Teste de toxicidade aguda com Daphnia similis com sedimento solubilizado.

\begin{tabular}{|c|c|c|c|c|c|c|c|c|}
\hline \multirow{2}{*}{ Amostra } & \multicolumn{3}{|c|}{ Variáveis da amostra } & \multicolumn{3}{|c|}{$\begin{array}{l}\text { No organismos imóveis }^{\text {Por réplica }} \\
\text { Pocalo }\end{array}$} & \multicolumn{2}{|c|}{ Imobilidade } \\
\hline & pH & $\begin{array}{c}\text { Condutividade } \\
\left(\mu \mathrm{S} / \mathrm{cm}^{2}\right)\end{array}$ & 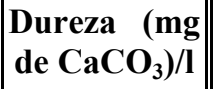 & 1 & 2 & 3 & Total & $\%$ \\
\hline Controle & 7,52 & 183,60 & 46 & 0 & 0 & 0 & 0 & 0.0 \\
\hline Estação 1 & 6,12 & 43,90 & 16 & 1 & 1 & 1 & 3 & 20,0 \\
\hline Estação 2 & 5,97 & 37,70 & 8 & 3 & 2 & 0 & 5 & 31,2 \\
\hline Estação 3 & 5,66 & 42,40 & 6 & 0 & 2 & 0 & 2 & 13,3 \\
\hline Estação 4 & 5,97 & 68,40 & 0 & 0 & 1 & 1 & 2 & 13,3 \\
\hline Estação 5 & 6,49 & 75,40 & 4 & 0 & 0 & 0 & $\mathbf{0}$ & 0.0 \\
\hline Estação 6 & 6,25 & 61,80 & 4 & 1 & 1 & 0 & 2 & 13,3 \\
\hline Estação 7 & 4,57 & 137,40 & 20 & 5 & 5 & 5 & 15 & 100.0 \\
\hline
\end{tabular}

Os testes com sedimento total, utilizando-se o organismo-teste Chironomus xanthus, indicaram toxicidade nas estações 6 e 7, ambas localizadas no rio Tietê, em pontos afastados da zona de confluência (represamento) (Tabela 11), e indícios de toxicidade nas demais estações. A maior mortalidade foi verificada na estação 7 , o que corrobora os resultados obtidos com o material solubilizado. ALMEIDA (2002), através de bioensaios crônicos com amostras de sedimentos do reservatório de Barra Bonita, verificou toxicidade ao organismo Chironomus xanthus em todas as amostragens realizadas. 
Tabela 11: Teste de toxicidade aguda com Chironomus xanthus com sedimento total.

\begin{tabular}{|c|c|c|c|c|c|c|c|}
\hline \multirow{2}{*}{ Amostra } & \multicolumn{3}{|c|}{$\mathrm{N}^{0}$ organismos imóveis } & \multicolumn{2}{|c|}{ Mortalidade } & \multicolumn{2}{|c|}{ Variáveis finais } \\
\hline & 1 & 2 & 3 & Total & $\%$ & pH & $\begin{array}{c}\text { Condutividade } \\
\qquad(\mu \mathrm{S} / \mathrm{cm})\end{array}$ \\
\hline Controle & 0 & 0 & 0 & 0 & 0 & 6,83 & 85,5 \\
\hline Estação 1 & 1 & 1 & 3 & 5 & 27,7 & 6,31 & 159,0 \\
\hline Estação 2 & 2 & 3 & 1 & 6 & 23,3 & 6,42 & 122,0 \\
\hline Estação 3 & 0 & 3 & 2 & 5 & 27,7 & 5,67 & 174,6 \\
\hline Estação 4 & 3 & 0 & 1 & 4 & 22,2 & 4,55 & 274,0 \\
\hline Estação 5 & 1 & 2 & 1 & 4 & 22,2 & 4,42 & 253,0 \\
\hline Estação 6 & 4 & 4 & 2 & 10 & 55,5 & 5,52 & 196,0 \\
\hline Estação 7 & 6 & 5 & 6 & 17 & 94,4 & 3,32 & 600,0 \\
\hline
\end{tabular}

COSTA \& ESPÏNDOLA (2001) constataram através de bioensaios crônicos com Ceriodaphnia silvestri e Ceriodaphnia dubia, em amostras de sedimento do reservatório de Barra Bonita e seus tributários, que as amostras de sedimentos do rio Tietê (estação localizada próxima aos pontos 6 e 7) apresentaram alta mortalidade de fêmeas adultas, baixa reprodução, baixa fecundidade e menor taxa intrínseca de crescimento populacional para os dois organismos-teste utilizados, em todos os períodos de coleta. Cabe ressaltar que nestas amostras os valores de $\mathrm{pH}$ e dureza diminuiram em relação à amostra controle, já a condutividade aumentou. Isto pode indicar uma maior liberação de contaminantes para a coluna de água, a partir do sedimento, fato que pode ter contribuído para o menor desenvolvimento dos organismos testes nas amostras. FRACÁCIO (2001), utilizando o organismo-teste Danio rerio, em reservatórios do Médio e Baixo Tietê, também verificou diminuição dos valores de $\mathrm{pH}$ e dureza e aumento de condutividade nas amostras que apresentaram toxicidade. Verifica-se que o padrão obtido no presente estudo é similar ao obtido pelos referidos autores, com valores de $\mathrm{pH}$ e dureza diminuindo ao final do teste, em relação ao controle do bioensaio utilizando-se Daphnia similis, como organismo teste. 
No bioensaio com Chironomus xanthus, a medida em que decresce o valor de $\mathrm{pH}$, aumenta a condutividade elétrica. Estas variáveis podem fornecer condições propícias à ressuspensão de poluentes nos sedimentos, afetando sensivelmente as taxas de mortalidade dos organismos-teste utilizados.

Constata-se, através do trabalho realizado por COSTA \& ESPÏNDOLA (2001), a presença das maiores concentrações de matéria orgânica (acima de 10\%) nos sedimentos do rio Piracicaba e Tietê, e as maiores frações de partículas finas (argila e silte). Associa-se a estas variáveis o fato destes locais apresentarem as maiores concentrações de metais biodisponíveis, durante o período de estudo. Os sedimentos do rio Piracicaba não apresentaram toxicidade aguda aos organismos testados, no entanto testes crônicos realizados pelos mesmos autores evidenciaram efeitos tóxicos destes sedimentos.

DORNFELD et al, (2002), obteve correlações significativas entre teor de matéria orgânica e toxicidade de sedimentos da Represa do Lobo e tributários, para os mesmos organismos-teste utilizados no presente estudo. Atribuiu-se esta correlação à maior capacidade de retenção de metais por sedimentos orgânicos.

No presente estudo verificou-se certa homogeneidade física dos sedimentos, representados basicamente por partículas finas (argila e silte) e orgânicas (sedimento com mais de $10 \%$ de matéria orgânica), em todas as estações de coleta (ver capítulo 2). Desta forma, não foram verificadas relações entre teor de matéria orgânica, granulometria e toxicidade. A toxicidade verificada, principalmente na Estação 7, possivelmente seja explicada pela alta concentração de nutrientes e metais adsorvidos às partículas de sedimento (ver capítulos 2 e 3 ).

Os resultados obtidos, tanto para o material solubilizado como para o sedimento total, através da exposição de dois organismos-teste distintos foram similares, com toxicidade nas estações 6 (Chironomus xanthus) e 7 (ambos). O percentual de mortalidade de Chironomus xanthus na estação 6 esteve pouco acima de 50\%, sendo que os valores de $\mathrm{pH}$ e condutividade não apresentaram variações evidenciadas, em relação à amostra controle. Segundo DORNFELD et al, (2002) deve-se analisar cuidadosamente os resultados de testes de toxicidade com sedimento, quando utiliza-se espécies bentônicas (Chironomus xanthus, por exemplo), pois a mortalidade pode ser ocasionada por fatores físicos do sedimento, isto é, além dos fatores químicos, a espécie bentônica testada pode não se adaptar ao tipo de sedimento, causando mortalidade dos exemplares testados. 
Desta forma, optou-se por comparar apenas os percentuais de mortalidade entre os organismos testes utilizados na estação 7, que apresentou toxicidade a Daphnia similis bem como a Chironomus xanthus. Através do teste " $T$ " (comparação de médias)(5\%), constatou-se que a ação tóxica dos sedimento sobre os dois organismosteste utilizados é a mesma (apresentaram taxa de mortalidade estatisticamente iguais).

Corroborando os resultados obtidos por COSTA \& ESPÏNDOLA (2001), os resultados dos testes de toxicidade do presente estudo demonstram o alto grau de impacto sofrido pelo rio Tietê, ao longo de sua extensão e a magnitude da influência deste sobre o ecossistema em estudo. 


\section{CONCLUSÕES}

A avaliação da toxicidade aguda dos sedimentos dos principais compartimentos iniciais do Reservatório de Barra Bonita, utilizando-se diferentes frações da amostra e organismos-teste, permite concluir que:

- Daphnia similis e Chironomus xanthus apresentaram elevada mortalidade quando expostos ao sedimento da estação 6 (rio Tietê). As amostras tóxicas a estes organismos apresentaram valores de $\mathrm{pH}$ e dureza geralmente inferiores às demais, bem como altos valores de condutividade. Estas condições podem contribuir com a ressuspensão de poluentes para a coluna de água, afetando sensivelmente os organismos expostos;

- Apesar dos altos teores de matéria orgânica e partículas finas observadas em todas as amostras, somente a estação 7 apresentou-se tóxica aos organismos;

- A toxicidade verificada na estação 7 possivelmente está associada a presença de altas concentrações de nutrientes e metais, observadas no período de estudo;

- Embora os organismos-teste utilizados não pertençam ao mesmo nível trófico, os organismos expostos aos sedimentos da estação 7 apresentaram percentuais de mortalidade estatisticamente iguais. A utilização de testes combinados (com diferentes frações da amostra e organismos teste utilizados) representa uma ferramenta importante para ensaios ecotoxicológicos, uma vez que estes testes podem confirmar ou reforçar a confiabilidade do mesmo;

- Os resultados obtidos evidenciam o alto grau de degradação do rio Tietê, depositário final de despejos domésticos e industriais de grandes pólos de desenvolvimento urbano, permitindo considerá-lo como local prioritário para a aplicação de medidas mitigadoras (estações de tratamento de efluentes, disposição adequada de resíduos, remoção de biomassa, entre outras). 


\section{REFERÊNCIAS BIBLIOGRÁFICAS}

ALMEIDA,C. A. (2002). Estudos ecotoxicológicos dos sedimentos de represas do rio Tietê com o organismo-teste bentônico Chironomus xanthus Rempel (Insecta:Diptera). São Carlos. 119p. Dissertação (Mestrado) - Escola de Engenharia de São Carlos - Universidade de São Paulo.

CONNELL, D. W. \& MILlER, G. J.(1984). Chemistry and ecotoxicology of pollution. John Wiley \& Sons, $444 p$.

COSTA, J.B \& ESPÏNDOLA, E. L. G. (2001). Avaliação ecotoxicológica da água e sedimento de tributários do reservatório de Barra Bonita (Médio Tietê Superior), IN: ESPÍNDOLA, E. L. G.; BOTTA-PASCHOAL, C. M. R.; ROCHA, O.; BOHRER, M. B. C. e OLIVEIRA-NETO, A. L., Ecotoxicologia: Perspectivas para o século XXI, p. 75-94. Editora RiMa, São Carlos, SP.

DIAS, L. E. ; MELLO, J.W.V. (1998) . Recuperação de áreas degradadas. Editora Folha de Viçosa Ltda. Viçosa . MG.

DORNFELD, C. B; MASSUTI, M. B.; SILVÉRIO, P. F.; ALMEIDA, C. A. (2002). Caracterização ecotoxicológica do sedimento da Represa do Lobo (ItirapinaBrotas, SP) e seus tributários. In: Recursos hidroenergéticos:usos, impactos e planejamento integrado. v 1.Editora:Rima, São Carlos p.75-90.

FERNICOLA, N. A. G. G.; BOHRER-MOREL, M. B. C.; BAINY, A C. D. (2003). Ecotoxicologia. In: AZEVEDO, F.A; CHASIN A. A. M. As bases toxicológicas da ecotoxicologia. São Carlos: RiMa- São Paulo: Intertox 340p.

FONSECA, A. L. (1997). Avaliação da Qualidade da Água na Bacia do Rio Piracicaba/SP Através de Testes de Toxicidade com Invertebrados. São Carlos. 216p. Tese (Doutorado). - Escola de Engenharia de São Carlos - Universidade de São Paulo. 
FRACÁCIO, R. (2001). Utilização de bioensaios ecotoxicológicos com Danio rerio (Cypriniformes, Cyprinidae) e análise limnológica para a avaliação ambiental dos reservatórios do Médio e Baixo Tietê (SP). São Carlos 233p. Dissertação (mestrado) Escola de Engenharia de São Carlos - Universidade de São Paulo.

GOLDSTEIN, E.G.; FERNÍCOLA, N. A. G. G.; ZAGATTO, P. A.; BERTOLETTI, E.; ARAUJO, R. P. A.; MOURA, A. C. N. (1981) . Contribuição da toxicologia Ambiental para o controle da poluição das águas. CETESB - São Paulo.

HILL, I. R.; MATTHIESSEN P.; HEIMBACH F. (1993). Guidance Document on Sediment toxicity tests an bioassays for freshwater and marine environments. In: Workshop on sediment toxicity assessment . Renesse, The Netherlands.

LAWS, E. A. (1993). Aquatic pollution: an introductory text. 2. ed. Interscience publication, John Wiley \& Sons, INC. New York, 611p.

OLIVEIRA-NETO, A. L. (2000). Toxicidade de alguns metais pesados (Cd, Cr e Pb) em organismos planctônicos lacustres de região subtropical. Tese de Doutorado. Escola de Engenharia - USP São Carlos.

RAND,G.M. \& PETROCELLI, S. R. (1985). Fundamentals of aquatic toxicology methods and applications. Washington,USA. Hemisphere Publishing. 666p.

MOZETO, A. A (2001). Workshop de avaliação do projeto qualised: bases técnicocientíficas para o desenvolvimento de critérios de qualidade de sedimentosexperimentos de campo e laboratório. São Carlos:UFSCAR 69p. 
Capítulo 5

"Densidade de microorganismos de interesse público (coliformes fecais) em sedimentos recentes dos rios Tietê e Piracicaba, nos seus compartimentos de entrada no Reservatório de Barra Bonita- SP"

\section{INTRODUÇÃO}

Todos os organismos requerem uma fonte de energia, sendo que as formas de carbono são as mais comumente necessárias. A maior parte dos organismos requer certos compostos orgânicos do carbono, como açúcares e outros carboidratos. As formas vivas que exigem uma fonte orgânica de carbono, incapazes de utilizar $\mathrm{CO}_{2}$ como única fonte, são denominados heterotróficos (PELCZAR et al., 1980)

As bactérias heterotróficas foram profundamente estudadas, pois neste grupo encontram-se todas as bactérias patogênicas para o homem, para os outros animais e para os vegetais, assim como a maior parte da população microbiana do ambiente humano (PELCZAR et al., 1980). Entre os diversos grupos de bactérias heterotróficas, encontra-se o grupo das enterobactérias (família Enterobacteriaceae), geralmente denominadas "coliformes". Constituem bacilos gram-negativos facultativos e muitos dos gêneros pertencentes a esta família têm 
sido estudados mais extensivamente do que qualquer outro tipo de bactérias, como é o caso do gênero Escherichia e Salmonella (COLLINS et al.,1995).

As enterobactérias são encontradas no trato intestinal humano e de outros animais. A Salmonella constitui gênero parasita e apresenta mais de 800 espécies conhecidas, todas patogênicas. A Escherichia habita normalmente o intestino e causa doenças apenas em circunstâncias excepcionais (PELCZAR, 1981). A Escherichia coli é o representante mais comum das bactérias coliformes fecais, proveniente do trato intestinal de humanos e outro animais de sangue quente (DUFOR,1977 apud DOYLE et al.,1992). A Agência de Proteção Ambiental (EPA) dos Estados Unidos recomendou o microorganismo Escherichia coli como o melhor indicador de poluição fecal para a avaliação da qualidade de ambientes de água doce.

Os germes enteropatogênicos, que causam a febre tifóide, as salmoneloses, a shiguelose e outras moléstias intestinais, são eliminados pelas excreções fecais e, possivelmente, pela urina. A partir destas fontes, as bactérias podem contaminar alimentos ou águas e invadir um segundo ou subseqüente hospedeiro, desde que este ingira o alimento ou as águas contaminadas (PELCZAR, 1981).

A contaminação dos ecossistemas aquáticos que vem ocorrendo ao longo dos anos é causada pelo desenvolvimento industrial, crescimento demográfico e ocupação do solo de forma intensa e acelerada, o que vem provocando o comprometimento dos recursos hídricos disponíveis para o consumo humano, aumentando consideravelmente o risco de doenças de transmissão hídrica (RIVERA \& MARTINS,1996).

A água potável da maior parte da população é obtida a partir de rios e lagos, podendo ser contaminada através do despejo de esgotos domésticos, industriais e lixiviamento de superfícies. A medida em que a população aumenta, a poluição se agrava, tornando-se um problema cada vez mais sério. Pela exigência de quantidades maiores de água existe a produção maior de despejos residuais, que serão descartados em uma extensão de água nos arredores, a qual pode ser a fonte de abastecimento hídrico ou até mesmo pode vir a entrar em contato com o 
sistema de abastecimento de cidades vizinhas. Como veículo potencial de germes patogênicos, as águas podem representar riscos para a saúde e a vida (PELCZAR, 1981).

A utilização de coliformes fecais como indicadores de qualidade de água baseia-se no fato destes estarem diretamente relacionados com a contaminação fecal de animais de sangue quente (entre os quais se inclui o homem), indicando que qualquer microorganismo patogênico que ocorra no trato intestinal desses animais pode estar presente (PELCZAR, 1996). Os indicadores servem para orientar a prática, formulando evidências para o diagnóstico e também instrumentalizando o sistema de informações de vigilância ambiental.

Os coliformes fecais presentes na água são predominantemente removidos pela absorção nas partículas suspensas e sedimentação das mesmas (DAVIES \& EVISON, 1991). Desta forma, altas densidades destes microrganismos acumulam-se no fundo de ecossistemas aquáticos, junto aos sedimentos (CRABILL et al.,1999)

De acordo com DOYLE et al. (1992), a densidade de coliformes fecais presente nos sedimentos de fundo de ecossistemas aquáticos tem sido considerada como o índice mais estável para a uma avaliação global da qualidade da água, mais até do que a densidade verificada na própria coluna d'água. Esta perceptível estabilidade é geralmente atribuída a fatores ambientais que promovem uma maior permanência dos coliformes no sedimento do que na água. De acordo com AN (2002), os coliformes presentes no sedimento podem, em determinadas condições, ressupender na coluna de água, representando fonte contínua de degradação da qualidade ambiental.

Excretas de origem humana ou animal são os principais veículos de propagação de uma variedade de enfermidades transmissíveis como febre tifóide, febre paratifóide, shigueloses etc (LIMA et al., 1999).

O reservatório de Barra Bonita, inserido em uma região de alta densidade demográfica, recebe diariamente altas cargas de esgoto in natura, transportados principalmente através dos rios Piracicaba e Tietê. O conhecimento da presença e quantidade de microorganismos de interesse público nos sedimentos dos 
compartimentos iniciais do reservatório constitui informação relevante sob o aspecto de monitoramento da qualidade da água deste sistema.

\section{OBJETIVO}

Caracterizar os sedimentos dos principais compartimentos iniciais do reservatório de Barra Bonita quanto a presença e densidade de microorganismo de interesse público (que podem afetar a saúde humana e de outro animais, considerando ainda a posição que ocupam na cadeia alimentar), no intuito de fornecer informações importantes a considerar nos programas de monitoramento da qualidade das águas do sistema.

\section{METODOLOGIA}

\subsection{EM CAMPO:}

As coletas foram realizadas em novembro de 2002, sendo as estações de coleta determinadas através de mapas topográficos, abrangendo áreas localizadas ao longo de cada tributário até a região do encontro de ambos. O Anexo 01 apresenta a localização do Reservatório de Barra Bonita, seus principais tributários e as estações de coleta. O Anexo 02 apresenta as coordenadas geográficas de cada estação de coleta:

As estações de coleta foram georreferenciadas com o uso do GPS Trimble Navigator, sendo estas coincidentes com estações já utilizadas em estudos anteriores e em andamento no Núcleo de Estudos de Ecossistemas Aquáticos (NEEA), do Centro de Recursos Hídricos e Ecologia Aplicada, da EESC/USP. 
Amostras recentes de sedimento foram extraídas com o auxílio de uma draga de Eckmam, em todas as estações de coleta, e acondicionadas em frascos limpos, evitando-se o contato direto com a amostra. Foram utilizadas caixas térmicas a aproximadamente $4^{\circ} \mathrm{C}$ para o transporte das amostras ao laboratório, que foi realizada rigorosamente no mesmo dia da coleta.

\subsection{EM LABORATÓRIO}

O cultivo e contagem das colônias de bactérias nas amostras de sedimento seguiu o método usualmente empregado no Laboratório de Saneamento Ambiental da EESC/USP. Este método permite a identificação de bactérias heterotróficas, bactérias coliformes (coliforme total), Escherichia coli (coliforme fecal) e Salmonella $s p$. (coliforme fecal patogênico). Foram retiradas alíquotas de $5 \mathrm{~mL}$ de sedimento (sedimento+água intersticial), sendo repassadas a provetas de $500 \mathrm{~mL}$ e misturadas a água destilada e agitadas durante 1 minuto. Alíquotas de $100 \mathrm{~mL}$ foram extraídas das provetas e diluídas 4 vezes em água destilada. Desta forma, cada amostra apresentou 4 diluições, as quais foram submetidas a técnica do filtro de membrana para o diagnóstico bacteriológico.

O método consiste nas seguintes etapas:

- Coloca-se um disco filtrante estéril (47 mm e 0,2 $\mu \mathrm{m}$ de diâmetro de poros) na unidade de filtração;

- Os volumes diluídos de sedimento passam através deste disco filtrante e as bactérias são retidas na superfície da membrana;

- A membrana é, então, removida e colocada sobre uma almofada absorvente, previamente saturada com o meio de cultura adequado (CHROMOCULT) e disposta em placa de Petri, as quais são incubadas durante 24 horas;

- Após a incubação, observam-se as colônias, desenvolvidas no disco filtrante nos locais em que as bactérias ficaram retidas no processo de filtração; 
- A contagem das colônias é manualmente, pela observação de diferentes colorações;

- O resultado é dado pelo número observado de colônias multiplicado pelo fator de diluição e expresso em Unidades Formadoras de Colônia por $100 \mathrm{~mL}$ de solução de sedimento ( UFC/ $100 \mathrm{~mL}$ ).

\subsection{ANALISE ESTATÍSTICA}

Aplicou-se aos dados adquiridos uma análise de agrupamento. O processamento das etapas de agrupamento e ligação resulta em uma matriz cofenética e, comparando-se esta com a matriz de associação tem-se o coeficiente de correlação cofenética que permite avaliar o grau de distorção proporcionado pela análise sobre os dados originais. De acordo com LEGENDRE (1983), são aceitáveis os índices superiores a 0,80. O coeficiente de correlação cofenética obtido neste estudo foi de 0,9476 , resultando portanto em pouca distorção dos dados originais. Optou-se pelo agrupamento em associação não ponderada (UPGMA), por atribuir similaridade entre pares de grupos de forma menos extrema, sendo que esta análise foi realizada no intuito de verificar a similaridade entre as estações de coleta.

\section{RESULTADOS E DISCUSSÕES}

4.1. Densidade e abundância relativa de bactérias heterotróficas, coliforme total, Escherichia coli e Salmonella sp. em sedimentos dos principais compartimentos iniciais do Reservatório de Barra bonita

$\mathrm{Na}$ Figura 25 são apresentados os resultados da densidade (UFC/100mL) de bactérias heterotróficas, coliformes totais, Escherichia coli e Salmonella sp. Ressalta-se que as bactérias heterotróficas englobam o grupo de enterobactérias ou coliformes. $\mathrm{O}$ grupo dos coliformes é extenso, com representantes de vários gêneros. No presente estudo os gêneros de interesse são: Escherichia (espécie Escherichia coli), um coliforme que habita normalmente o trato intestinal de animais de sangue quente; 
Salmonella sp (suas várias espécies), microrganismo patogênico, causador de inúmeras infecções intestinais.

Devido a presença destes microorganismos nas fezes humanas, eles alcançam os corpos d'água através dos despejos de esgoto e podem representar risco de epidemias, quando patogênicos, pelo consumo de água ou alimentos contaminados.

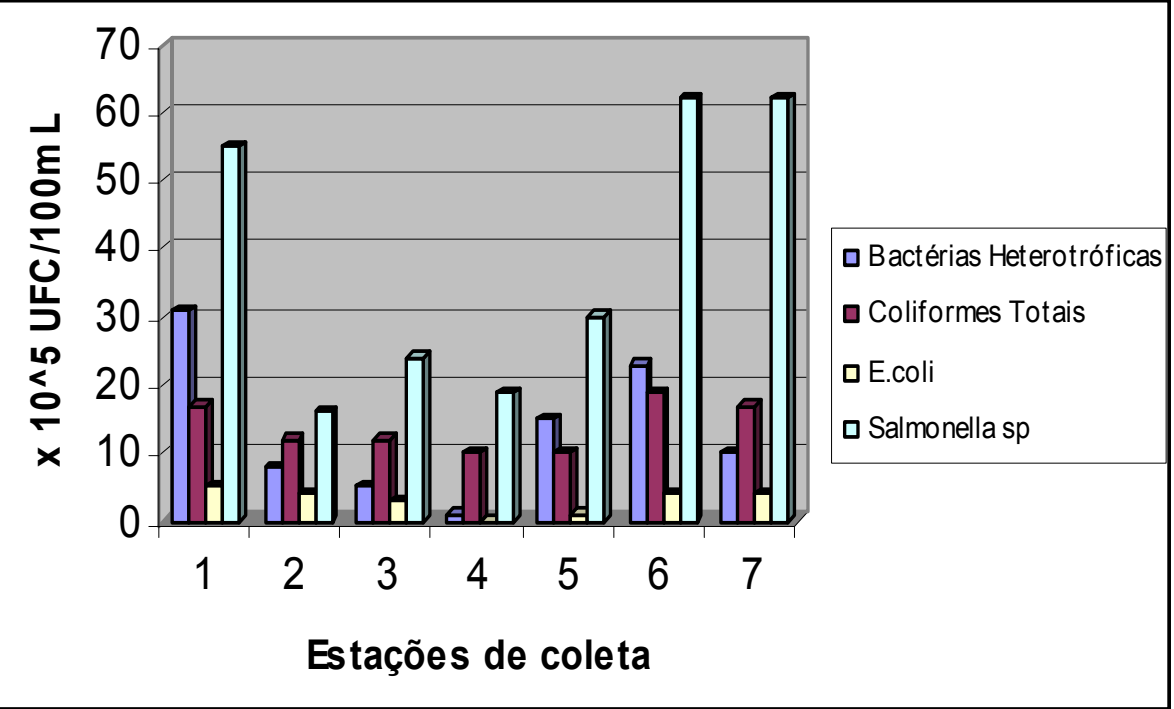

Figura 25: Densidade de bactérias nos sedimentos das diferentes estações de coleta

Verifica-se a dominância da enterobactéria patogênica Salmonella sp em todas as estações de coleta, com altas densidades variando entre $16 \times 10^{5} \mathrm{UFC} / 100 \mathrm{~mL}$ e $62 \times 10^{5}$ $\mathrm{UFC} / 100 \mathrm{~mL}$

De acordo com PELCZAR (1981), uma pessoa sadia não deveria eliminar, naturalmente, organismos patogênicos, o que faria ao desenvolver uma infecção intestinal. Assim, a presença deste tipo de coliforme no sistema é encarada como um sinal de alarme: a água está sujeita a uma poluição potencialmente perigosa.

A ocorrência de surtos de salmonelose é evidenciada em todas as partes do mundo, mas com menos freqüência em regiões onde se praticam a adequada eliminação dos despejos biológicos e a purificação das águas. Estas bactérias não se multiplicam em ambientes aquáticos, no entanto podem aí sobreviver durante 1 semana. Entre as diversas espécies e variedades de Salmonella destaca-se a Salmonella typhi, causadora 
da febre tifóide no homem, no entanto muitas espécies não oferecem riscos a saúde humana (PELCZAR, 1981).

Quanto a distribuição espacial das densidades de Salmonella sp. ao longo das estações de coleta, observa-se que as maiores densidades são verificadas nas estações iniciais (Estação 1-rio Piracicaba e Estações 6 e 7-rio Tietê).

Com relação a Escherichia coli, pode-se observar que a densidade foi inferior aos demais microrganismos, com a máxima de $5 \times 10^{5}$ UFC/100mL, na estação 1 (rio Piracicaba) e ausência do microrganismo na região de confluência entre os rios Piracicaba e Tietê. AN et al. (2002) encontraram a máxima de $5 \times 10^{5} \mathrm{UFC} / 100 \mathrm{~mL}$ nos sedimentos do Lago Texoma -EUA, e verificou que a densidade deste microrganismo no sedimento foi extremamente maior do que na água, sendo evidenciada a ressuspensão de bactérias a partir do sedimento nos meses de verão, proveniente das atividades de recreação, como a utilização de barcos e lanchas. Desta forma, em locais utilizados para recreação, a presença de Escherichia coli nem sempre indica contaminação fecal recente, podendo refletir a simples ressuspensão das bactérias depositadas nos sedimentos pelos movimentos de botes, barcos e lanchas.

A densidade máxima de coliformes totais encontradas nas amostras de sedimento foi de $19 \times 10^{5}$ UFC/100mL, na estação 6 (rio Tietê). AN et al. (2002), analisando os sedimentos do Lago Texoma- EUA, local de alta influência antrópica, detectou a densidade máxima de $28 \times 10^{5} \mathrm{UFC} / 100 \mathrm{~mL}$.

A máxima densidade observada na análise das bactérias heterotróficas (não incluindo os coliformes totais, a E.coli e Salmonella $s p$ ) foi de $31 \times 10^{5} \mathrm{UFC} / 100 \mathrm{~mL}$, na estação 1 (rio Piracicaba), a mínima observada foi de 1 x $10^{5}$ UFC/100mL.

Na Figura 26 são apresentados os resultados de abundância relativa de bactérias em cada estação de coleta. Verifica-se que a maior parte dos microrganismos presentes corresponde aos coliformes fecais, com maior incidência do patógeno Salmonella sp. Deve-se considerar o fato de que todas as salmonelas são patogênicas, no entanto nem todos os tipos causam enfermidades ao homem. A presença abundante deste microrganismo fornece indícios de baixa qualidade ambiental, já que a incidência de patógenos além de evidenciar a presença de material fecal, pode comprometer seriamente a qualidade da água. Sabe-se que o tempo de vida da Salmonella sp, em ambientes aquáticos é de aproximadamente 1 semana, desta forma o padrão encontrado no presente estudo poderá ser reflexo de uma situação pontual, embora não represente impossibilidade de contato e conseqüente dano a saúde. Práticas de recreação, pesca, 
irrigação de hortas e pomares, constituem atividades que podem promover o contato humano direto com a situação acima abordada. Para a irrigação de pomares e hortaliças, por exemplo, os maiores riscos se relacionam com a contaminação de hortaliças ingeridas cruas. Assim, não é recomendada a irrigação dessas plantas com águas que contenham elevados índices de coliformes, indicando altas concentrações de matéria fecal, dado que esta é portadora de ovos de vermes parasitas e cistos de alguns protozoários, como as amebas e a giárdias, normalmente transmitidas através das verduras.

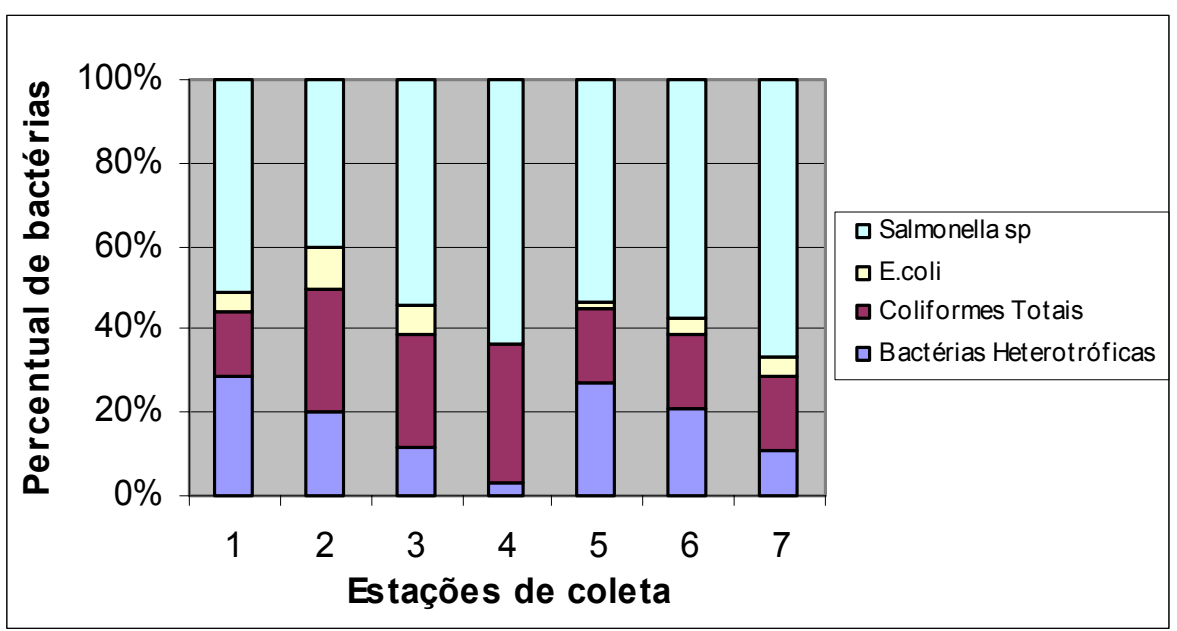

Figura 26: Abundância relativa de microrganismos nos sedimentos das diferentes estações de coleta

Embora não existam parâmetros estabelecidos de limite de coliformes em sedimentos, as densidades de organismos podem ser consideradas altas, similares aos valores encontrados por AN et al. (2002) em um lago altamente impactado (Lago Texoma -EUA). No entanto, o enfoque deve ser dado não somente a densidade de microrganismos encontrados, e sim ao tipo patogênico evidenciado em todas as estações de coleta. As maiores densidades de todos os microrganismos analisados foram observadas nas estações 1 (rio Piracicaba), 6, 7 (rio Tietê). Estas estações estão localizadas nos pontos mais distantes da região de confluência, ou seja, em um local de transição entre o ambiente lótico e lêntico. Na área influenciada pelo represamento a velocidade da corrente diminui e os microrganismos são levados a menores distâncias. 
Segundo FLINT (1987), a densidade de coliformes de origem fecal (representado neste estudo por Escherichia coli e Salmonella sp.) é influenciada por diversos fatores ambientais. Altas temperaturas, $\mathrm{pH}$ elevado e altos níveis de oxigênio dissolvido e radiação solar intensa aumentam a taxa de mortalidade destes microrganismos.

$\mathrm{O}$ ambiente sedimentar é caracterizado por apresentar temperaturas inferiores à coluna d'água, condição de anoxia e baixa (ou nenhuma) incidência de radiação solar, promovendo um ambiente adequado à vida destes microrganismos.

GOUGH \& STHAHL (2002), em estudos de densidade de bactérias em sedimentos, verificaram as maiores densidades em sedimentos contaminados por metais, em relação aos sedimentos não contaminados. Este é um indicador significativo de que as bactérias podem persistir em ambientes extremamente contaminados, no entanto outros fatores como o estoque de nutrientes, propriedades físicas do sedimento e taxas de predação por outros organismos podem influenciar consideravelmente o padrão encontrado. 


\subsection{ANÁLISE DE AGRUPAMENTO (CLUSTER)}

Na Figura 27 apresenta-se o Cluster formado a partir do agrupamento dos dados existentes de modo a reuni-los num mesmo conjunto.

Ao "corte" em 100.000 (distância euclidiana média), pode-se observar a formação de dois grupos distintos: o primeiro grupo, formado pelas estações 2,3 (rio Piracicaba), 4 (confluência) e 5 (rio Tietê); o segundo grupo, formado pelas estações 1 (rio Piracicaba), 6 e 7 (rio Tietê).

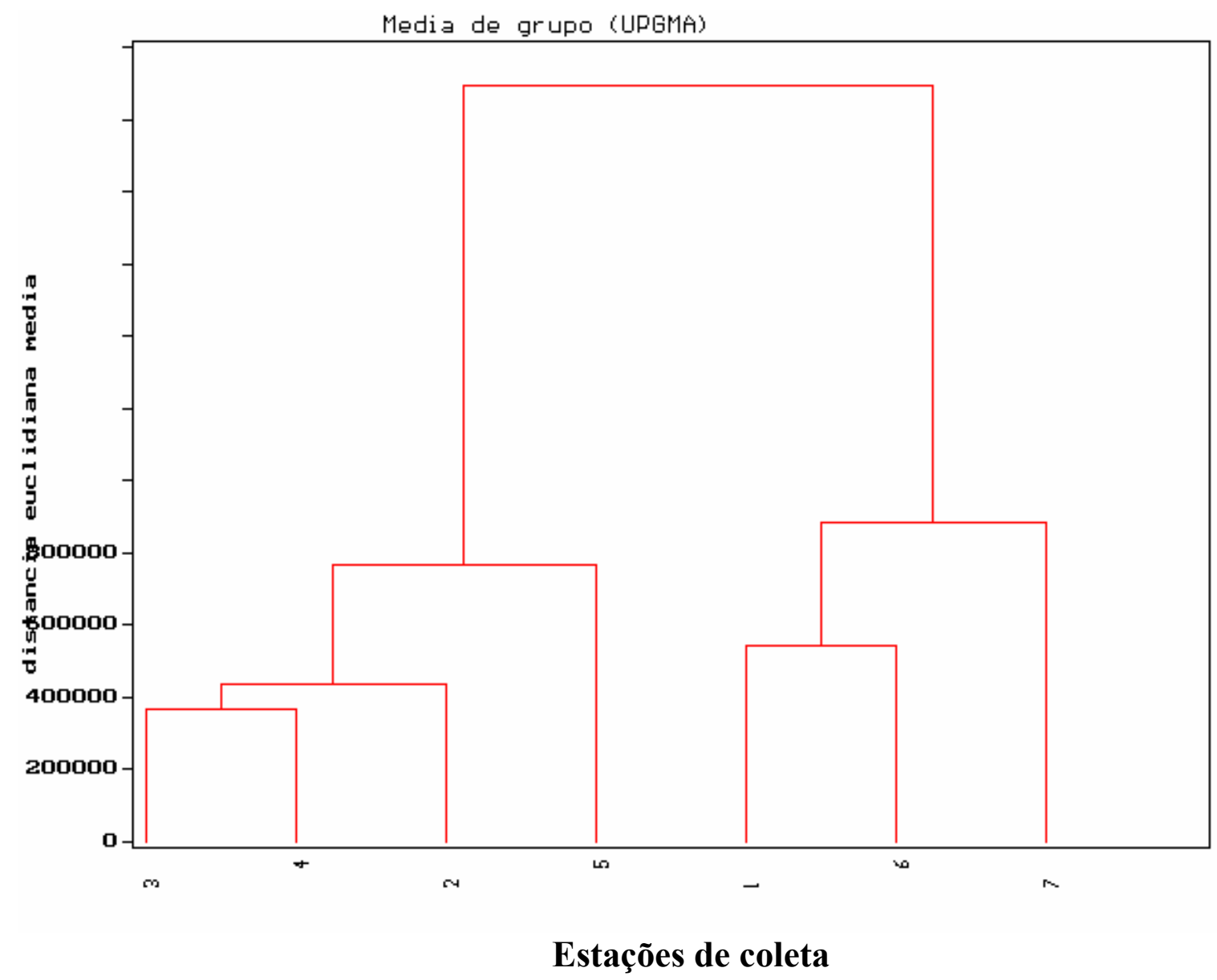

Figura 27: Cluster da densidade de microorganismos presentes nos sedimentos, em cada estação de coleta. 
Verifica-se através da análise de Cluster que os agrupamentos observados constituem duas condições distintas, sendo um grupo formado pelas estações localizadas na área influenciada pelo represamento e outro grupo formado pelas estações da zona de transição entre os ambientes lótico e lêntico. $\mathrm{O}$ ambiente lótico apresenta um fluxo de água como função de força principal, caracterizado pela alta taxa de transporte de material alóctone, já o ambiente lêntico apresenta menor turbulência, menor força de fluxo e consequentemente maior deposição de material particulado. $\mathrm{Na}$ região de transição ainda ocorrem fenômenos de transporte consideráveis, no entanto dá-se início a um processo de deposição contínuo nestes locais. Cabe ressaltar que as estações 6 e 7, localizadas no rio Tietê, além de apresentarem as maiores densidades de microrganismos, ainda apresentaram-se como os locais mais impactados, pelo acúmulo de nutrientes, contaminação por metais e efeitos tóxicos aos organismos-teste. Os mecanismos de funcionamento hidráulico, os processos de deposição de sedimentos e outros sólidos suspensos e condições físicas e químicas dos sedimentos nestas estações, possivelmente fornecem condições adequadas a manutenção e viabilidade dos microrganismos analisados neste estudo. 


\section{CONCLUSÕES}

Com base nos resultados obtidos pode-se concluir que:

- As altas cargas de esgoto in natura despejados no rio Piracicaba e no rio Tietê conferem a eles densidades consideráveis de microrganismos de interesse público, depositados nos sedimentos (Coliformes fecais);

- A alta densidade e predominância de bactérias patogênicas em todas as estações amostradas revelam péssimas condições sanitárias, com reflexos na qualidade da água deste sistema. A presença de coliformes fecais indica não somente a presença de material fecal, como também dá indício de que outros patógenos do trato intestinal de animais de sangue quente e do próprio homem poderão estar presentes;

- Os sedimentos deste sistema constituem fonte contínua de degradação da qualidade da água, já que algumas atividades (navegação, recreação e afins) podem promover a ressuspensão dos coliformes para a coluna d'água;

- O cenário apresentado compromete, entre outros, a utilização deste local para captação de água para a irrigação, principalmente de verduras e hortaliças, em geral ingeridas sem cozimento;

- Apesar dos patógenos do trato intestinal não se reproduzirem nos ecossistemas aquáticos e não sobreviverem por mais de 7 dias nestes locais, existe a possibilidade de contato com a água e alimentos utilizados pela população, constituindo fonte potencial de contaminação;

- As estações localizadas na zona de transição entre os ambientes lótico e lêntico apresentaram as maiores densidades de microrganismos, 
constituindo um grupo distinto. Acredita-se que os coliformes sejam extremamente resistentes em sedimentos de locais altamente impactados, representando, portanto, um bom indicador na avaliação da qualidade ambiental;

- As condições que proporcionam o desenvolvimento dos microrganismos não foram testadas neste estudo, no entanto sabe-se que o compartimento sedimento apresenta condições de anoxia, baixa (ou nenhuma) radiação solar e temperaturas inferiores a da coluna d'água, fatores que beneficiam a vida dos mesmos. $\mathrm{O}$ estoque de nutrientes é outro fator que pode contribuir no desenvolvimento destes microrganismos;

- O conhecimento das interações entre o compartimento sedimento e a coluna d'água, introduz mudanças substanciais em programas de monitoramento da qualidade da água, tanto para consumo, quanto para irrigação e balneabilidade. A presença de Escherichia coli (coliforme fecal) nem sempre indica contaminação fecal recente, sendo que muitas vezes reflete a simples ressuspensão das bactérias depositadas nos sedimentos por alterações turbulentas da coluna d'água. 


\section{REFERÊNCIAS BIBLIOGRÁFICAS}

AN, Y.; KAMPBELL, D. H.; BREIDENBACH, G. P. (2002). Escherichia coli and total coliforms in water and sediment at lake marinas. Environmental Pollution v.120, p. 771-778.

COLLINS, C. H.; LYNE, P. M.; GRANGE, J. M. (1995). Microbiolocal methods. 7 ed. Oxford :Butterworth-Heinemann. 493p.

CRABILL, C.; DONALD, R.; SNELLING, J.; FOUST, R.; SOUTHAM, G. (1999) The impact of sediment fecal coliform reservoirs on seasonal water quality in Oak Creek, Arizona. Water Research. v.33 p.2163-2171.

DAVIES, C. M.; EVISON, L. M. (1991). Sunlight and the survival of enteric bacteria in natural waters. J. Appl. Bacteriology v.70 p. 265-274.

DOYLE, J. D.; TUNNICLIFF, B.; KRAMER, R.; KUEHL, R.; BRICKLER, S. K. (1992). Instability of fecal coliform populations in water and bottom sediments at recreational beaches in Arizona. Water Research. v. 26 p. 979-988.

FLINT, K. P. (1987). The long-term survival of Escherichia coli in river water. J. Appl. Bacteriology.v.63 p. 261-270.

GOUGH, H. L.; STHAL, D. A. (2002). Optimization of direct cell counting in sediment. Journal of Microbiological Methods v.52 p 39-46.

LEGENDRE, L. (1983). Measures of ecological resemblance. In: Numerical Ecology: Developments in Environmental Modelling. E. Scientific Publishing Company, $317 \mathrm{p}$. 
LIMA, C. L. S; BRAZ, V. N.; RIVERA, I. G. (1999). Pesquisa de coliformes e estreptococos fecais em um ambiente aquático protegido. Engenharia Sanitária e Ambiental v.4 n.3 e 4 p.127-132.

PELCZAR, M. J.; REID, R.; CHAN, E. C. S. (1980). Microbiologia v.1. São Paulo: McGraw-Hill do Brasil 546p.

PELCZAR, M. J.; REID, R.; CHAN, E. C. S. (1981). Microbiologia v.2. São Paulo: McGraw-Hill do Brasil 1065p.

PELCZAR, M. J. (1996) Microbiologia das águas naturais, potáveis e dos esgotos. In: Microbiologia, Conceitos e Aplicações . v.2. Makron Books. p.337-61.

RIVERA, I. N. G; MARTINS, M. T. (1999). Bactérias enteropatoG6enicas no ambiente aquático. Rev. Ciên. Farm., v.64, p.24-28. 


\section{Capítulo 6}

\section{"Considerações Finais"}

Com base nos resultados obtidos a partir da análise da qualidade dos sedimentos dos principais compartimentos iniciais do Reservatório de Barra Bonita, pode-se concluir:

A partir da década de 60, houve grandes mudanças em relação ao desenvolvimento da região do Médio Tietê Superior e da Bacia do Piracicaba, como a transformação dos cenários urbanos (proporcionado em grande parte pelo êxodo rural) e a melhoria na infra-estrutura regional, facilitando a implantação de grandes pólos industriais. Tais processos de uso e ocupação dos solos trouxeram impactos diretos sobre a qualidade das águas dos rios Piracicaba e Tietê, conferindo aos depósitos sedimentares altas concentrações de poluentes e de microorganismos de interesse público. 
Dos tributários que afluem diretamente ao reservatório, o rio Tietê é o mais intensamente impactado, fornecendo altas concentrações de nutrientes e, apresentando altas densidades de microrganismos indicadores de poluição fecal, provenientes de despejos de esgotos domésticos de inúmeras cidades da região e da grande São Paulo. Além disso, apresenta-se altamente poluído por metais como o manganês, cádmio, chumbo e níquel, com grandes frações fracamente ligadas aos sedimentos. A situação verificada no rio Tietê confere toxicidade a organismos utilizados em teste (Daphnis similis e Chironomus xanthus), caracterizando possíveis riscos a biota aquática;

O rio Piracicaba apresentou menor grau de impacto, no entanto registrou-se indícios de toxicidade e concentrações de metais no sedimento que representam futuros riscos de poluição. As concentrações de metais fracamente ligados aos sedimentos apresentaram valores altos, o que pode conferir toxicidade a organismos expostos por um período de tempo maior (toxicidade crônica). Acredita-se que o rio Piracicaba tenha seus impactos minimizados pelo Reservatório de Salto Grande, localizado a montante;

Pode-se também observar certa sincronicidade entre o desenvolvimento antropogênico das regiões do Médio Tietê Superior e Bacia do Piracicaba e a magnitude da degradação ambiental do compartimento inicial do reservatório, visto que a partir da década de 70 os processos de uso e ocupação dos solos apresentaram mudanças substanciais, verificada nos depósitos sedimentares. $\mathrm{O}$ crescimento industrial e o intenso processo de eutrofização das água do reservatório são evidenciados nas camadas sedimentares, pois a partir deste período foram registradas altas concentrações de cobre nas camadas sedimentares. Isto pode ser reflexo do intenso crescimento da indústria metalúrgica e conseqüente despejo de seus efluentes não tratados como também do uso constante de algicidas (por exemplo, sulfato de cobre), utilizado na contenção do crescimento de algas típicas do processo de eutrofização, iniciado durante este período e reflexo da acelerada ocupação urbana registrada a partir de então.

Os resultados obtidos neste estudo reforçam a necessidade de adoção de medidas de manejo e recuperação, principalmente no rio Tietê, de forma a integrar tanto os tributários que drenam suas águas para este rio de maior porte como a racionalização 
dos processos de uso e ocupação dos solos, face ao desenvolvimento urbano acelerado. A melhoria das condições ambientais e a manutenção da qualidade dos recursos hídricos disponíveis, em uma abordagem integrada entre água e sedimento, virá a contribuir de forma efetiva na elaboração de planos de manejo/gestão e a implantação eficaz de programas de recuperação. 


\section{Anexos}

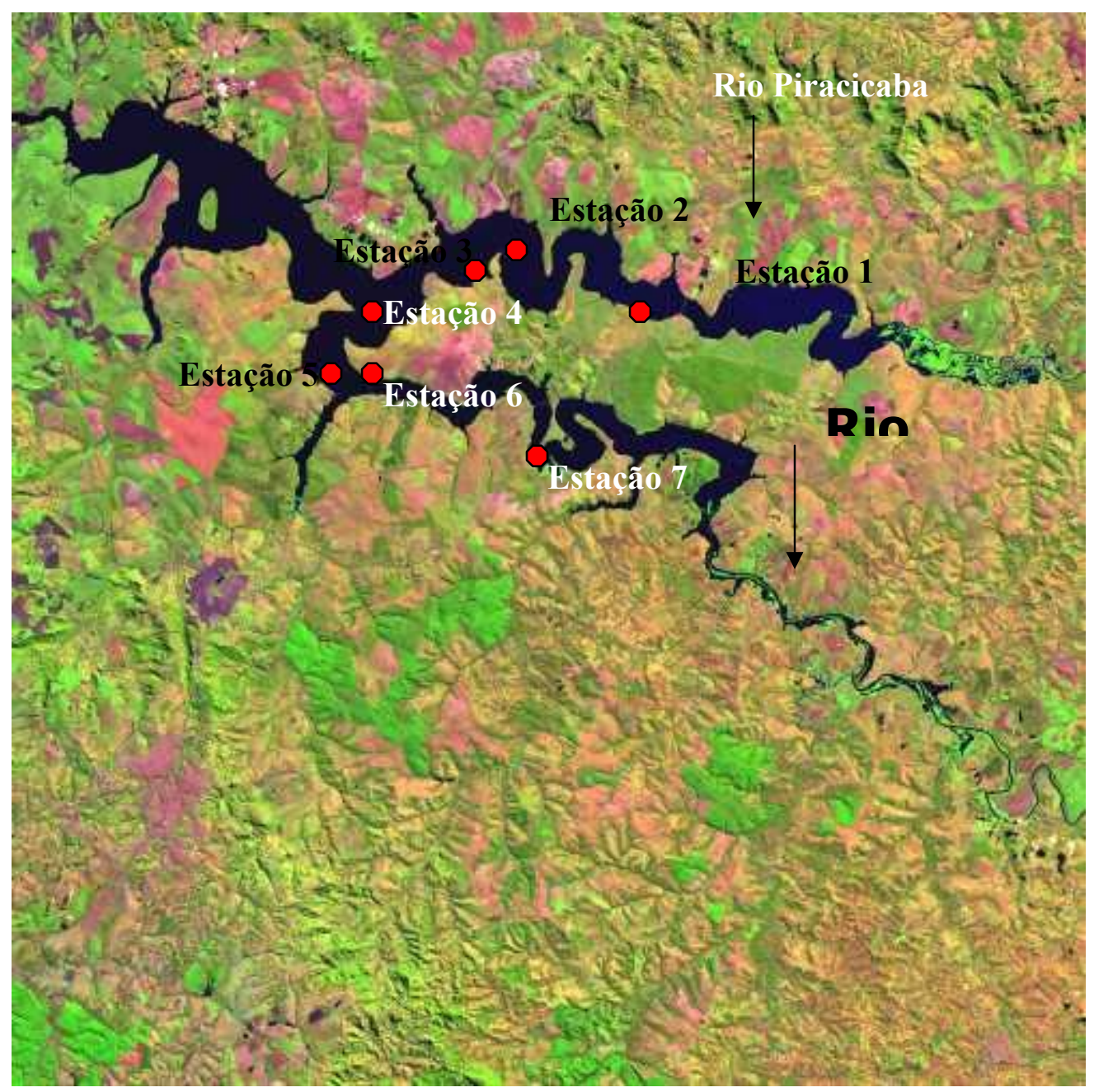

ANEXO 01: Imagem do satélite LANDSAT em escala 1: 100.000 do Reservatório de Barra Bonita e a localização das estações de coleta

(Fonte : www.cdbrasil.cnpm.embrapa.br) 


\begin{tabular}{|c|c|c|c|}
\hline Estação de coleta & Tributário & \multicolumn{2}{|c|}{ Coorde Coordenadas geográficas } \\
\hline Estação 1 & rio Piracicaba & $22^{\circ} 37^{\prime} 10.51^{\prime \prime} \mathrm{S}$ & $48^{\circ} 12^{\prime} 24.41^{\prime \prime} \mathrm{W}$ \\
\hline Estação 2 & rio Piracicaba & $22^{\circ} 35^{\prime} 38.26^{\prime \prime} \mathrm{S}$ & $48^{\circ} 14^{\prime} 50.48^{\prime \prime} \mathrm{W}$ \\
\hline Estação 3 & rio Piracicaba & $22^{\circ} 35^{\prime} 59.17^{\prime \prime} \mathrm{S}$ & $48^{\circ} 17^{\prime} 14.07^{\prime \prime} \mathrm{W}$ \\
\hline Estação 4 & região de confluência & $22^{\circ} 36^{\prime} 55.76^{\prime \prime} \mathrm{S}$ & $48^{\circ} 20^{\prime} 13.01^{\prime \prime} \mathrm{W}$ \\
\hline Estação 5 & rio Tietê & $22^{\circ} 40^{\prime} 2.75^{\prime \prime} \mathrm{S}$ & $48^{\circ} 20^{\prime} 57.14^{\prime \prime} \mathrm{W}$ \\
\hline Estação 6 & rio Tietê & $22^{\circ} 40^{\prime} 10.70^{\prime \prime} \mathrm{S}$ & $48^{\circ} 19^{\prime} 26.41^{\prime \prime} \mathrm{W}$ \\
\hline Estação 7 & rio Tietê & $22^{\circ} 42^{\prime} 15.82^{\prime \prime} \mathrm{S}$ & $48^{\circ} 14^{\prime} 48.91^{\prime \prime} \mathrm{W}$ \\
\hline
\end{tabular}

ANEXO 02: Coordenadas geográficas das estações de coleta 

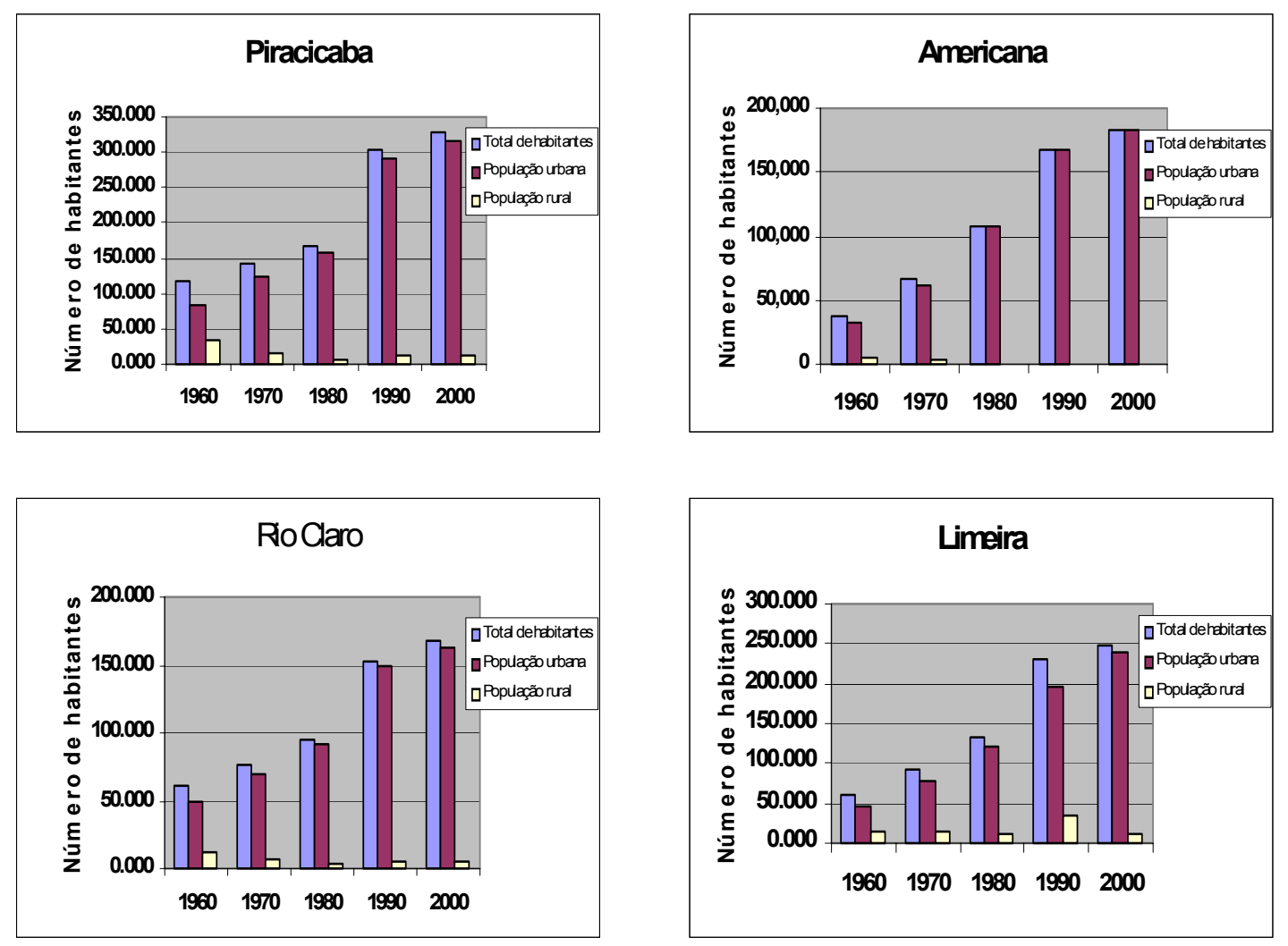

ANEXO 03 A: Demografia dos municípios selecionados, da bacia do Piracicaba, a partir de 1960. 

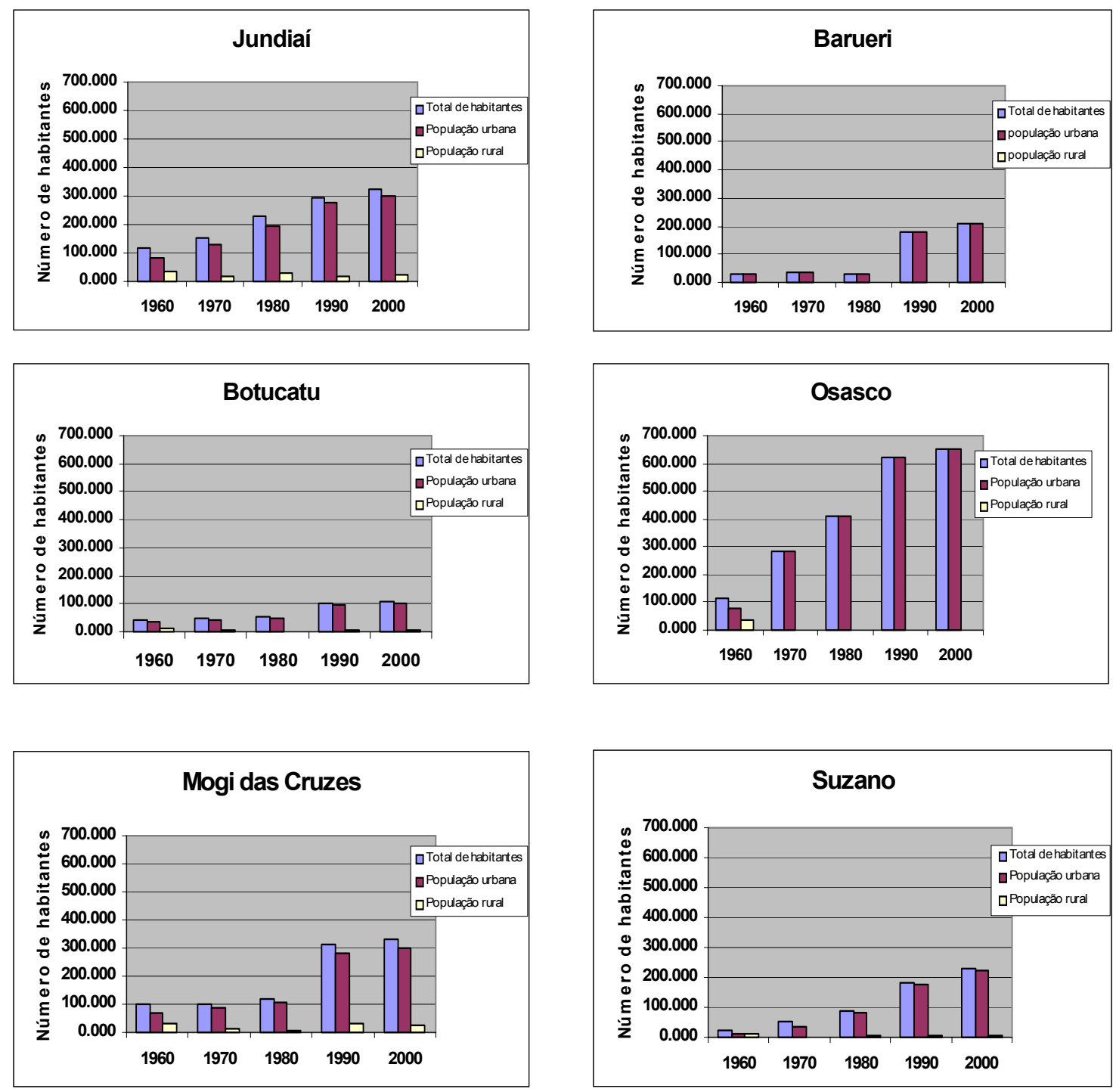

ANEXO 03 B: Demografia dos municípios selecionados, da bacia do Médio Tietê Superior, a partir de 1960. 

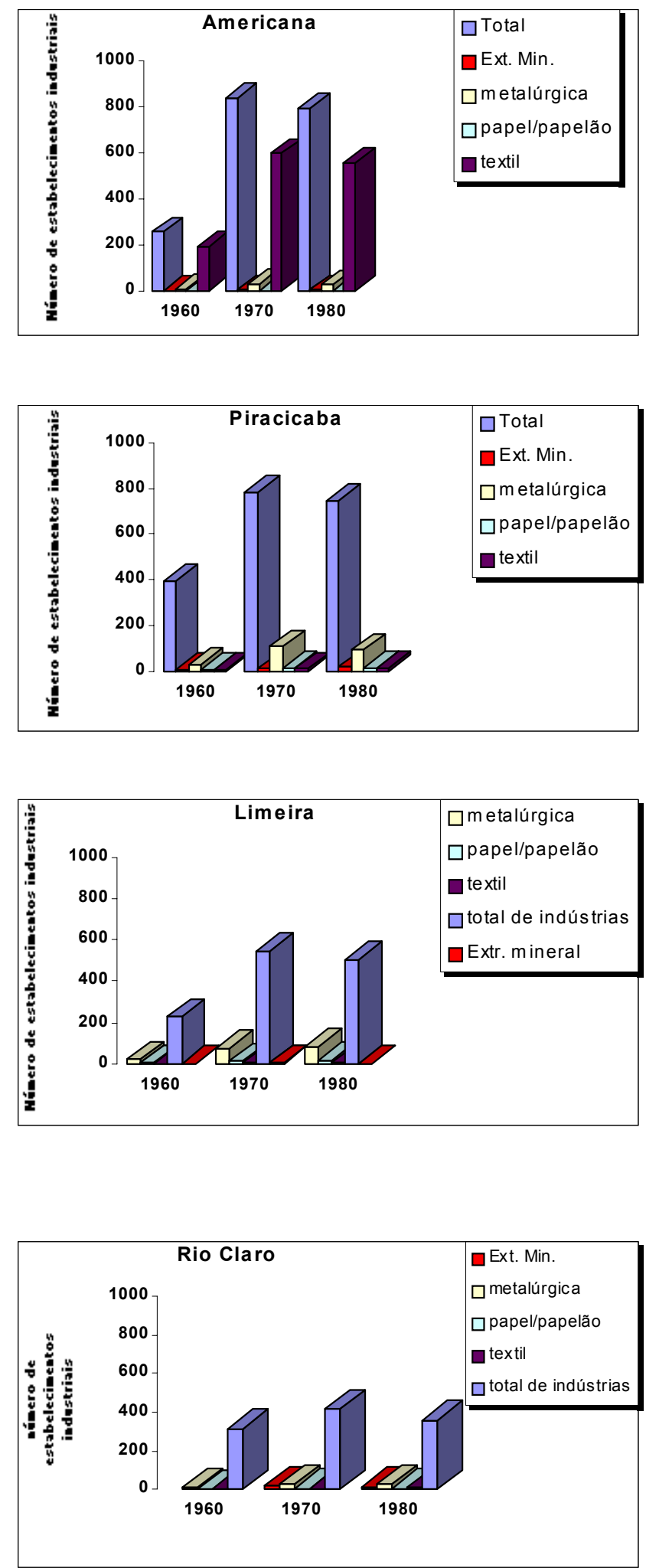

ANEXO 03 C: Número de indústrias, por gênero, nas cidades selecionadas na bacia do Piracicaba, a partir de 1960. 

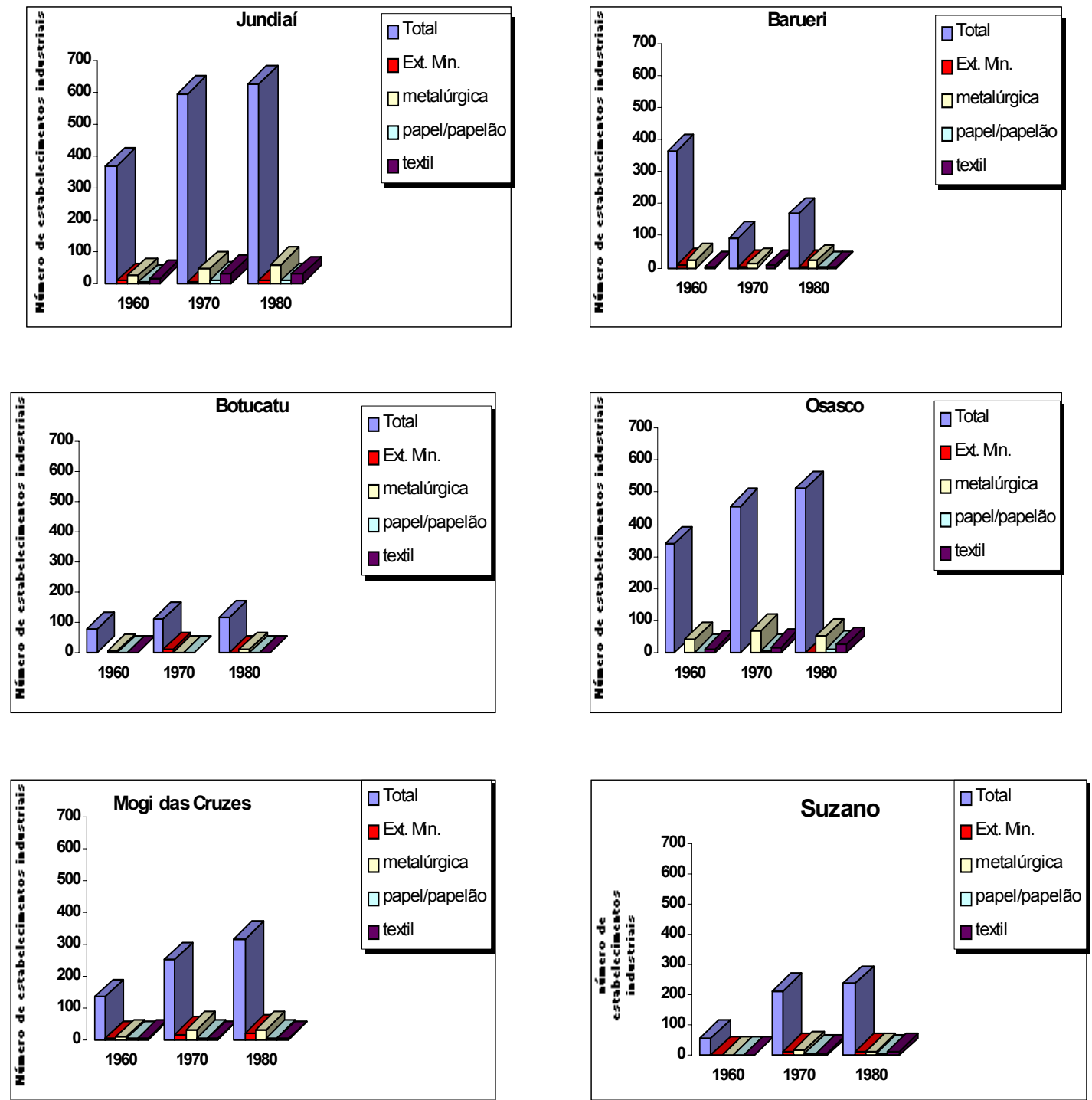

ANEXO 03 D: Número de indústrias, por gênero, nas cidades selecionadas na bacia do Médio Tietê Superior, a partir de 1960. 

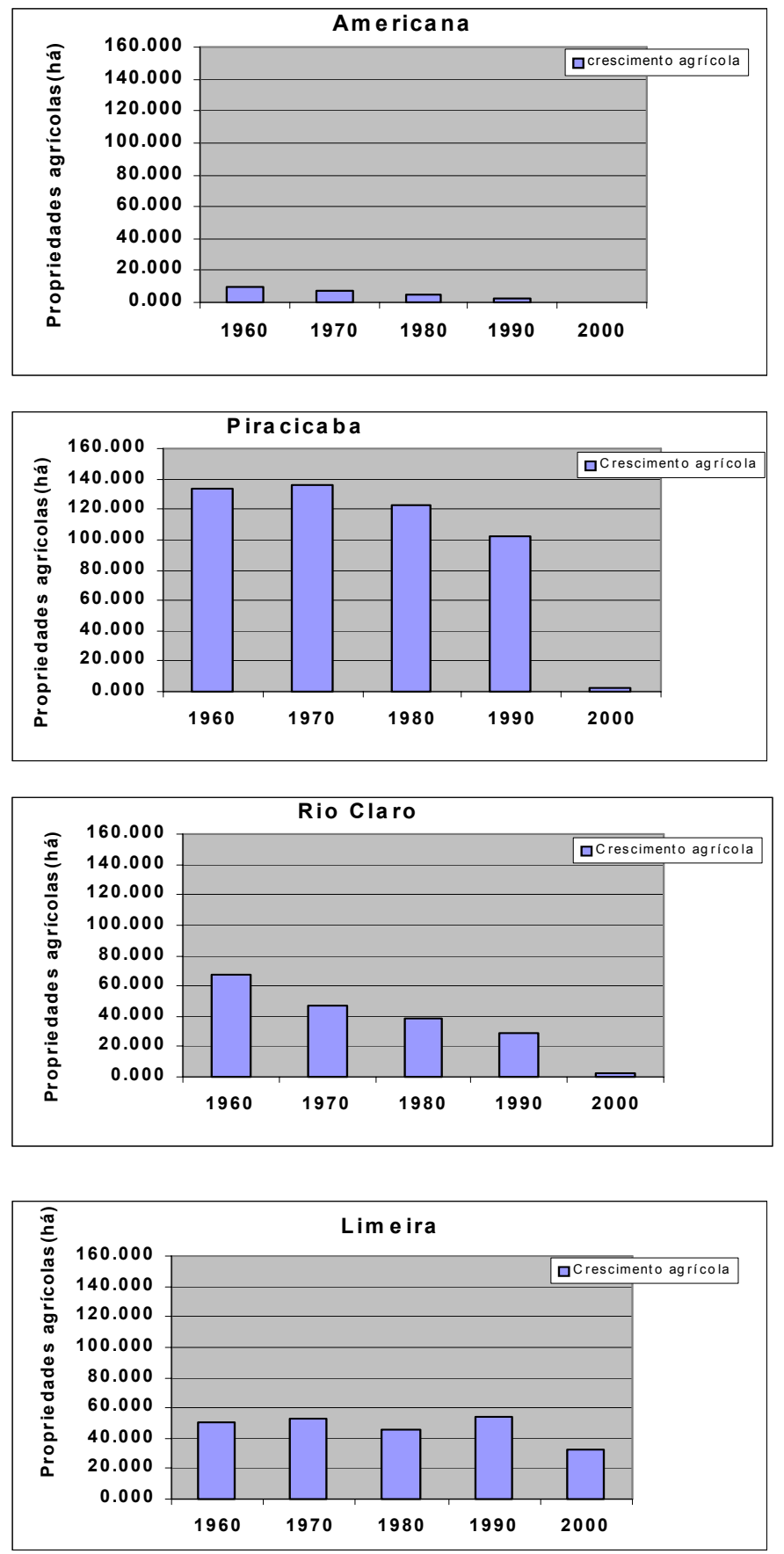

ANEXO 03 E: Propriedades agrícolas, em hectares, ocupadas por cultura permanente,nas cidades selecionadas na bacia do Piracicaba 

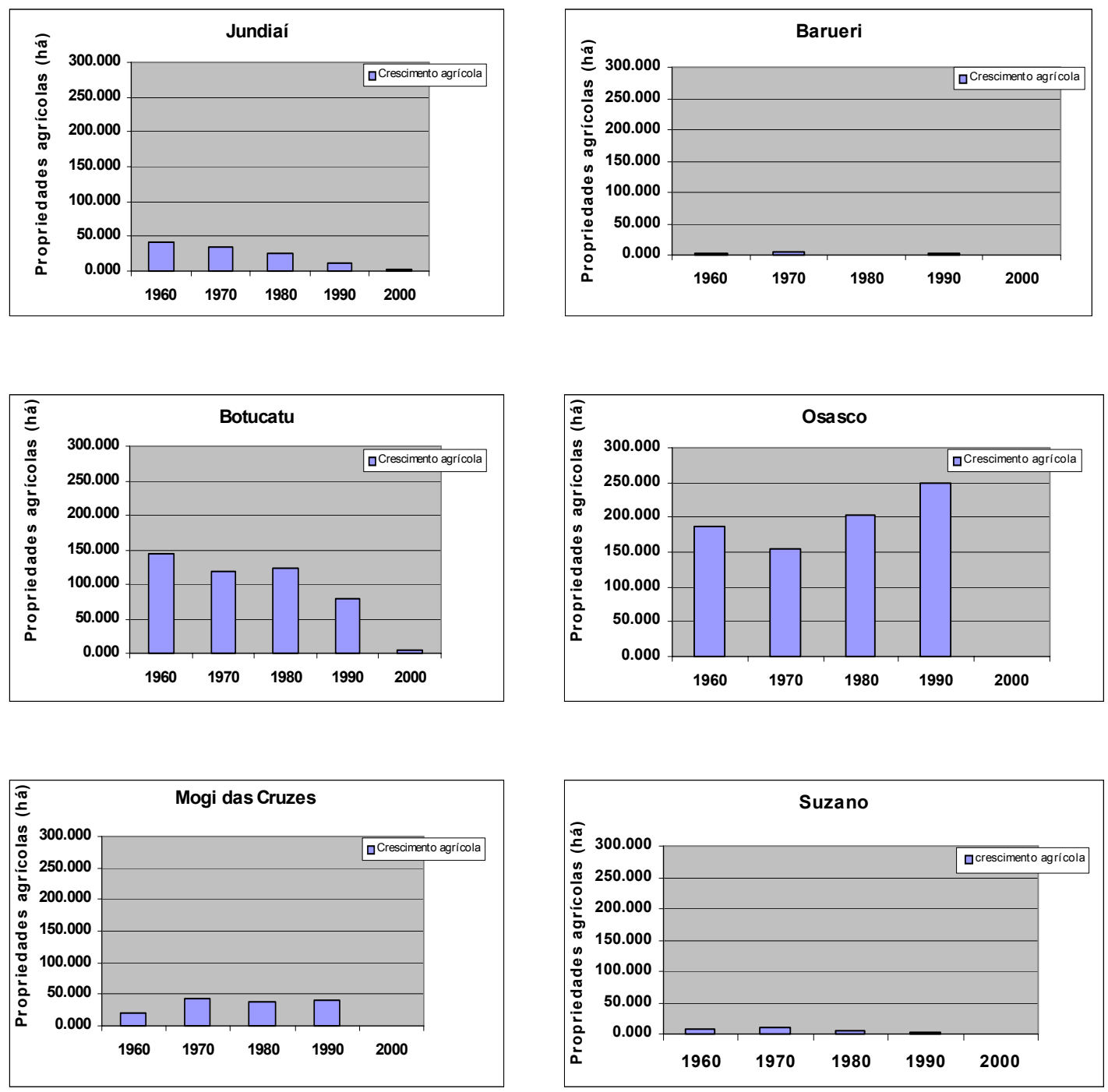

ANEXO 03 F: Propriedades agrícolas, em hectares, ocupadas por cultura permanente nas cidade selecionadas do Médio Tietê Superior 


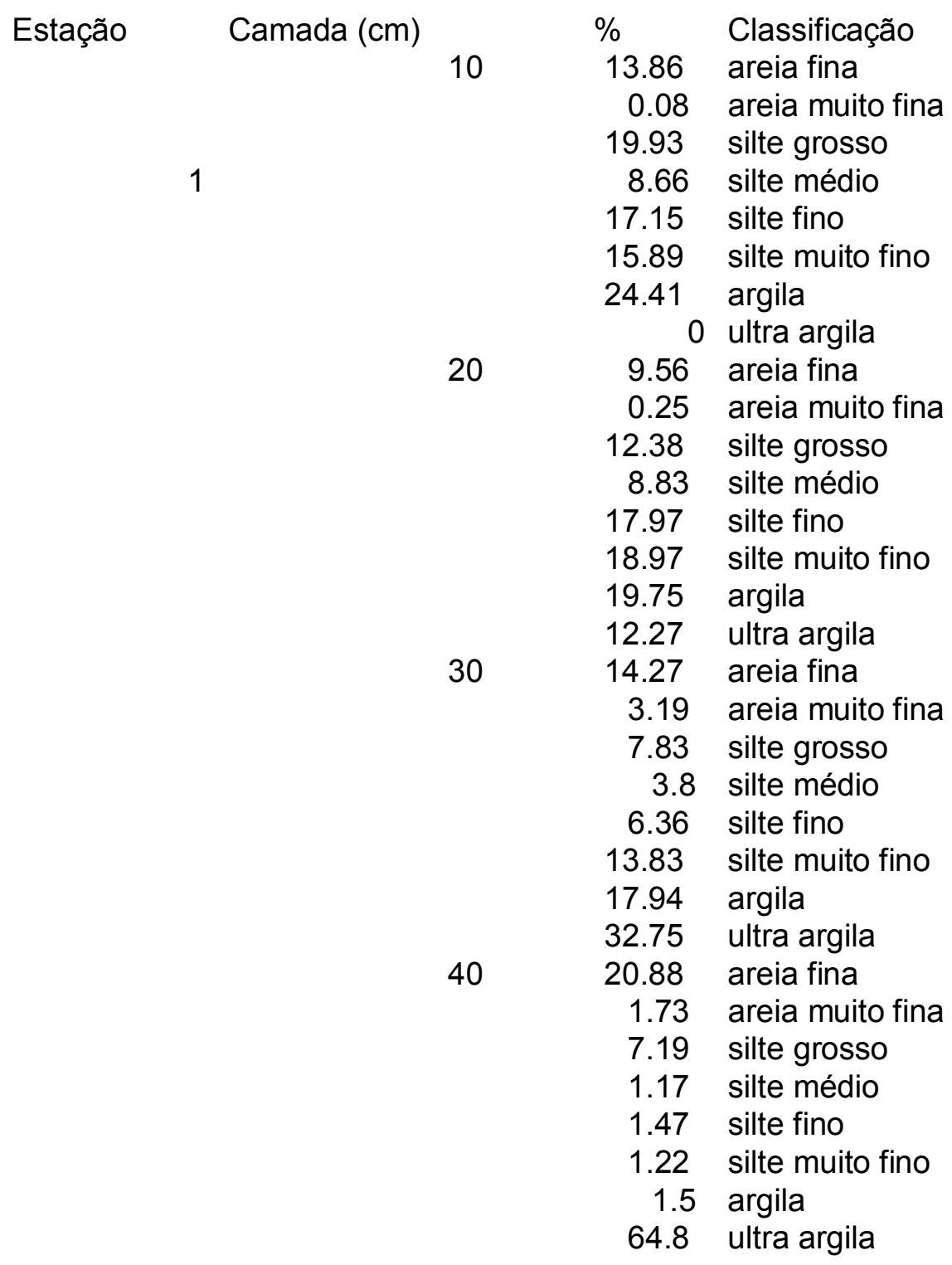




\begin{tabular}{|c|c|c|c|c|}
\hline Estação & Camada $(\mathrm{cm})$ & $\begin{array}{l}20 \\
30\end{array}$ & $\begin{array}{r}\% \\
12.85 \\
8.08 \\
11.54 \\
13.62 \\
17.25 \\
23.99 \\
6.62 \\
6.02 \\
4.99 \\
4.83 \\
10.66 \\
13.19 \\
7.72 \\
9.52 \\
9.88 \\
39.17 \\
13.92 \\
2.11 \\
20.8 \\
25.49 \\
4.58 \\
13.55 \\
20.25 \\
\end{array}$ & $\begin{array}{l}\text { Classificação } \\
\text { areia fina } \\
\text { areia muito fina } \\
\text { silte grosso } \\
\text { silte médio } \\
\text { silte fino } \\
\text { silte muito fino } \\
\text { argila } \\
\text { ultra argila } \\
\text { areia fina } \\
\text { areia muito fina } \\
\text { silte grosso } \\
\text { silte médio } \\
\text { silte fino } \\
\text { silte muito fino } \\
\text { argila } \\
\text { ultra argila } \\
\text { areia fina } \\
\text { areia muito fina } \\
\text { silte grosso } \\
\text { silte médio } \\
\text { silte fino } \\
\text { silte muito fino } \\
\text { argila } \\
\text { ultra argila }\end{array}$ \\
\hline tação & Camada $(\mathrm{cm})$ & 10 & $\begin{array}{r}\% \\
4.14 \\
2.11 \\
16.58 \\
17.69 \\
12.22 \\
14.66 \\
18.05 \\
14.52 \\
6.2 \\
0.69 \\
9.38 \\
8.69 \\
8.3 \\
11.05 \\
12.86 \\
42.8\end{array}$ & $\begin{array}{l}\text { Classificação } \\
\text { areia fina } \\
\text { areia muito fina } \\
\text { silte grosso } \\
\text { silte médio } \\
\text { silte fino } \\
\text { silte muito fino } \\
\text { argila } \\
\text { ultra argila } \\
\text { areia fina } \\
\text { areia muito fina } \\
\text { silte grosso } \\
\text { silte médio } \\
\text { silte fino } \\
\text { silte muito fino } \\
\text { argila } \\
\text { ultra argila }\end{array}$ \\
\hline
\end{tabular}

ANEXO 04: Análise granulométrica (continuação) 


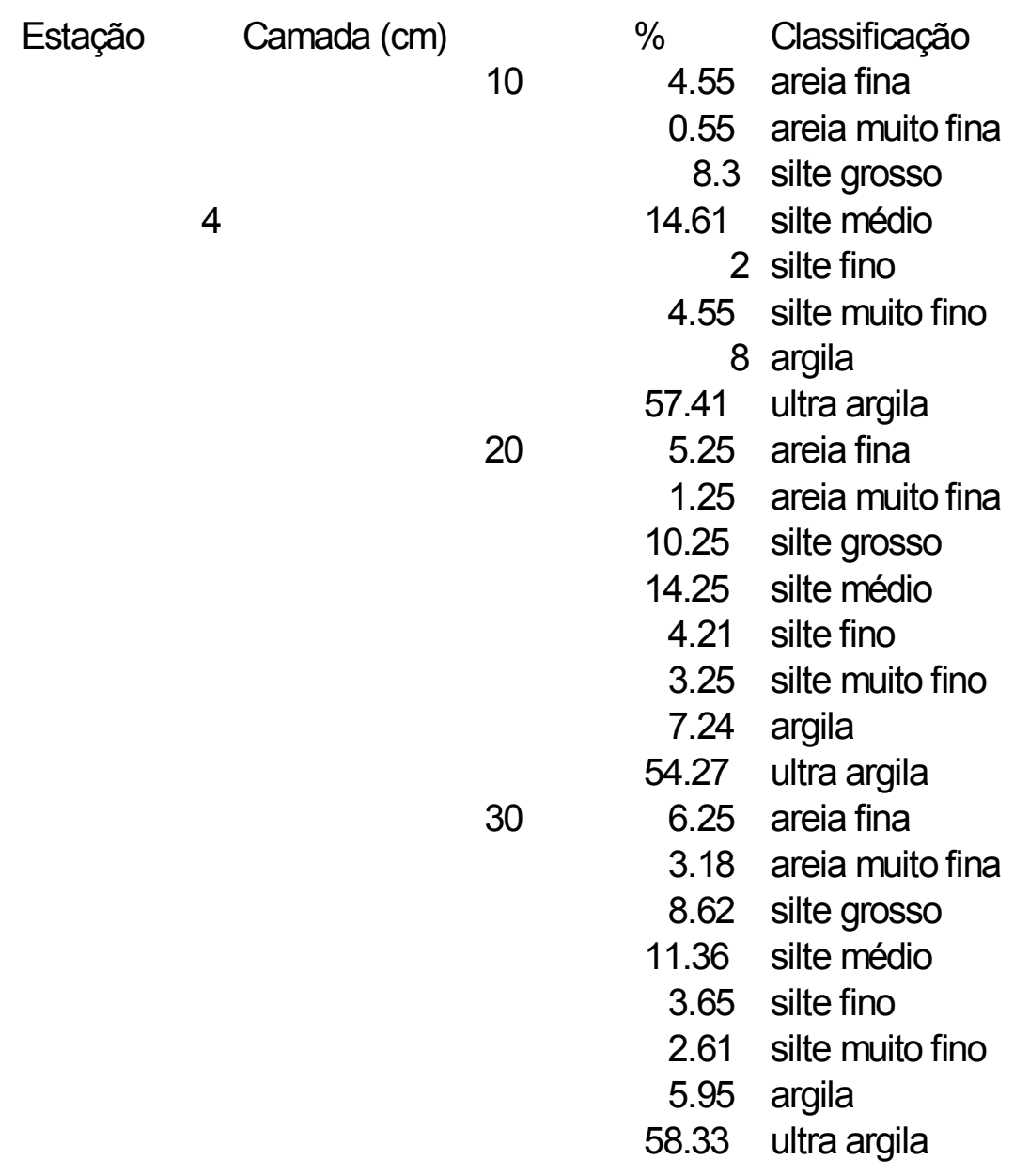

ANEXO 04: Análise granulométrica (continuação) 


\begin{tabular}{|c|c|c|c|}
\hline \multirow[t]{5}{*}{ Estação } & Camada $(\mathrm{cm})$ & $\%$ & Classificação \\
\hline & 10 & 2.3 & areia fina \\
\hline & & 1.62 & areia muito fina \\
\hline & & 14.23 & silte grosso \\
\hline & & 4.23 & silte médio \\
\hline \multirow{28}{*}{5} & & 7.68 & silte fino \\
\hline & & 35.39 & silte muito fino \\
\hline & & 23.54 & argila \\
\hline & & 10.91 & ultra argila \\
\hline & 20 & 0.99 & areia fina \\
\hline & & 0.94 & areia muito fina \\
\hline & & 18.77 & silte grosso \\
\hline & & 6.72 & silte médio \\
\hline & & 6.72 & silte fino \\
\hline & & 51.69 & silte muito fino \\
\hline & & 1.027 & argila \\
\hline & & 13.11 & ultra argila \\
\hline & 30 & 3.62 & areia fina \\
\hline & & 2.63 & areia muito fina \\
\hline & & 12.69 & silte grosso \\
\hline & & 6.28 & silte médio \\
\hline & & 6.29 & silte fino \\
\hline & & 25.39 & silte muito fino \\
\hline & & 17.25 & argila \\
\hline & & 25.8 & ultra argila \\
\hline & 40 & 3.25 & areia fina \\
\hline & & 1.5842 & areia muito fina \\
\hline & & 7.95 & silte grosso \\
\hline & & 10.95 & silte médio \\
\hline & & 14.26 & silte fino \\
\hline & & 20.36 & silte muito fino \\
\hline & & 37.62 & argila \\
\hline & & 3.99 & ultra argila \\
\hline
\end{tabular}

ANEXO 04: Análise granulométrica (continuação) 


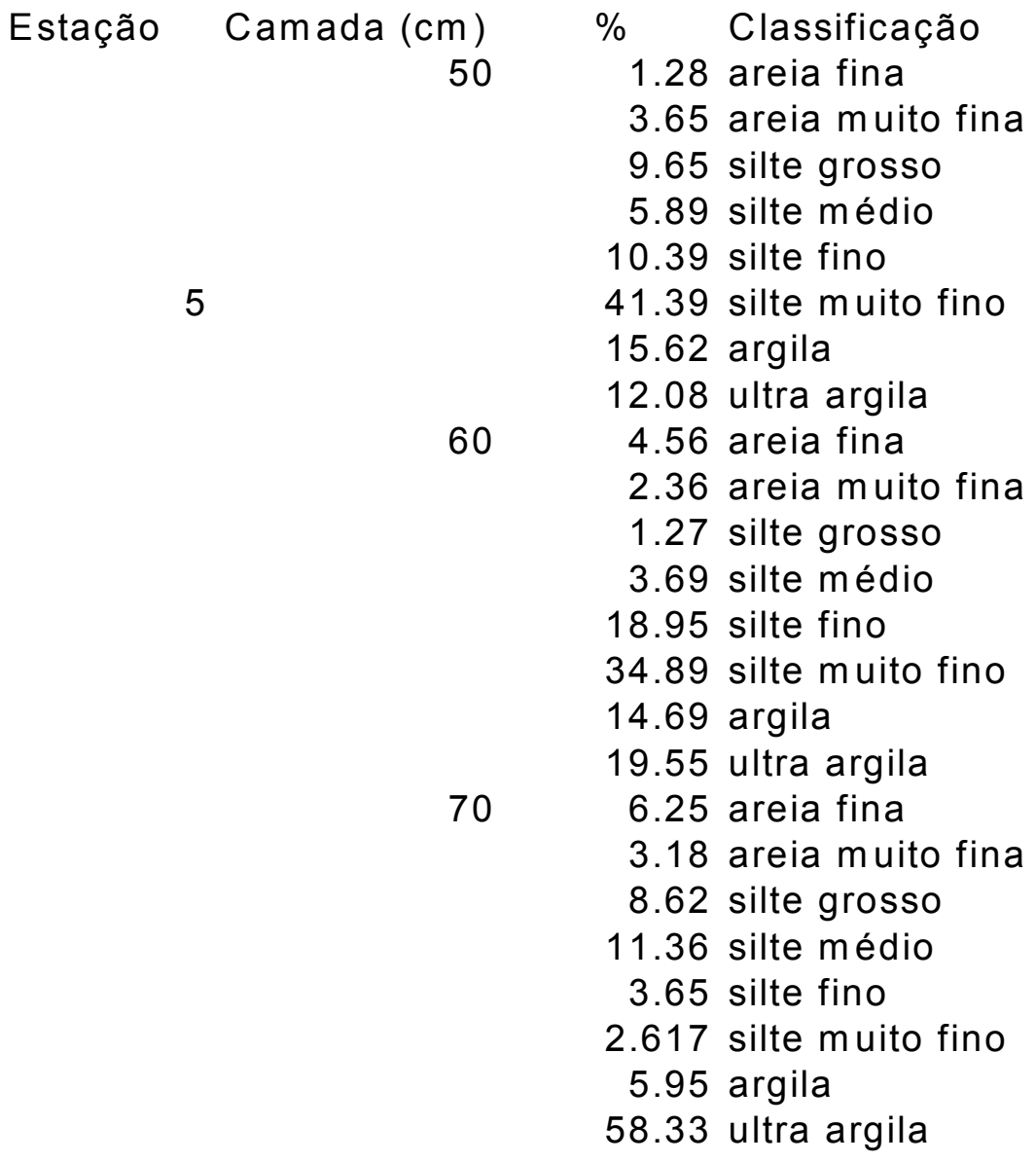

ANEXO 04: Análise granulométrica (continuação) 


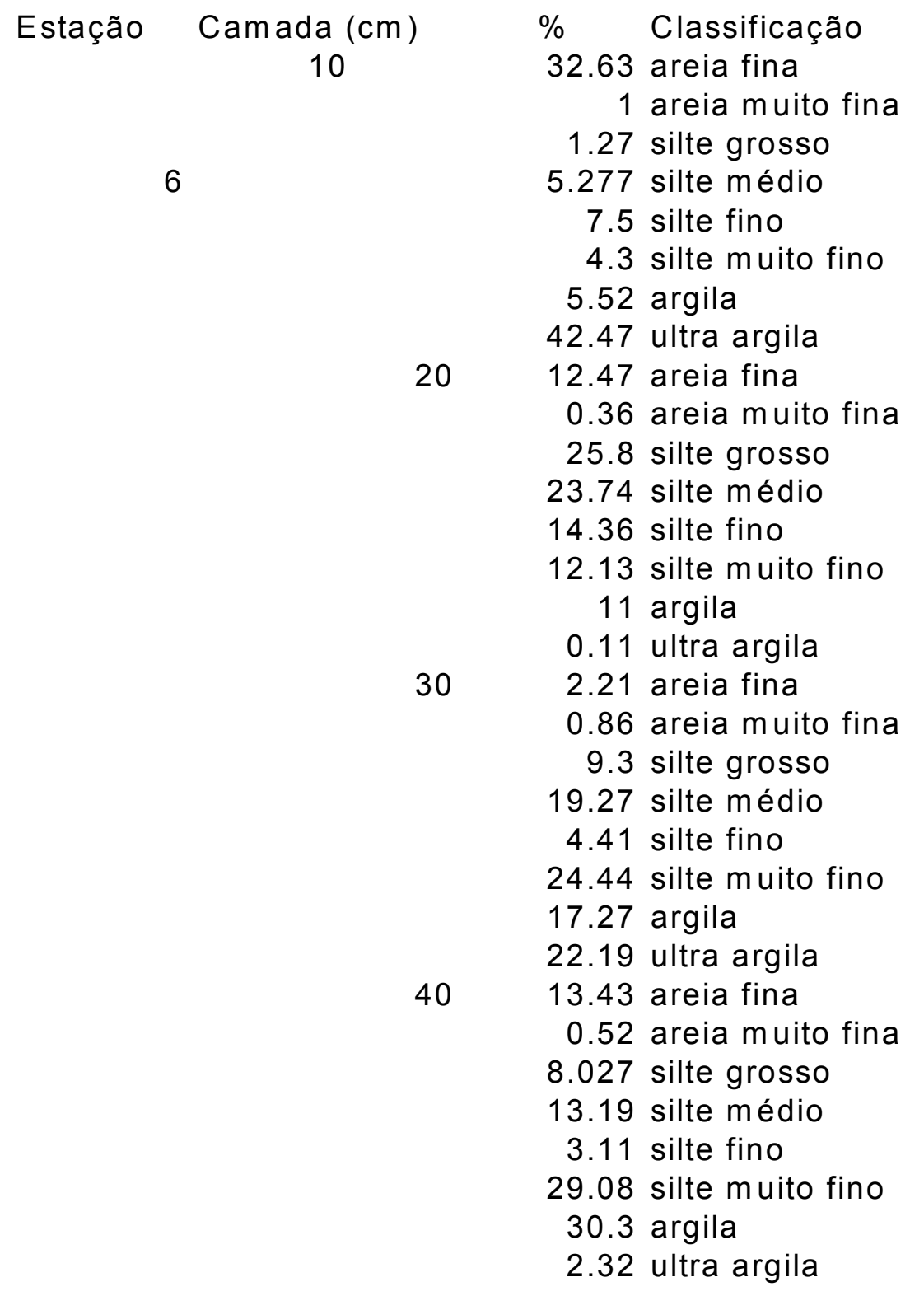

ANEXO 04: Análise granulométrica (continuação) 


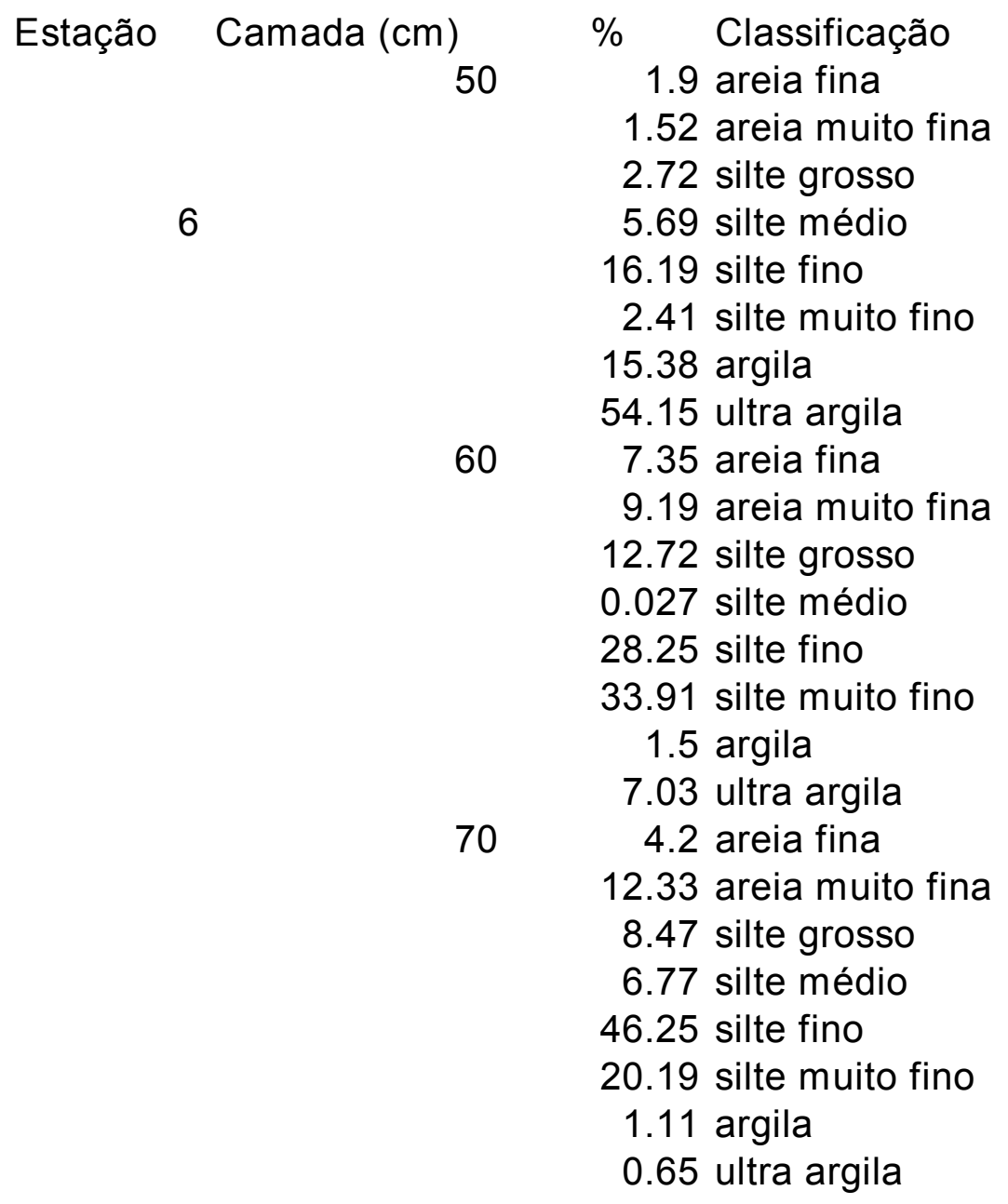

ANEXO 04: Análise granulométrica (continuação) 


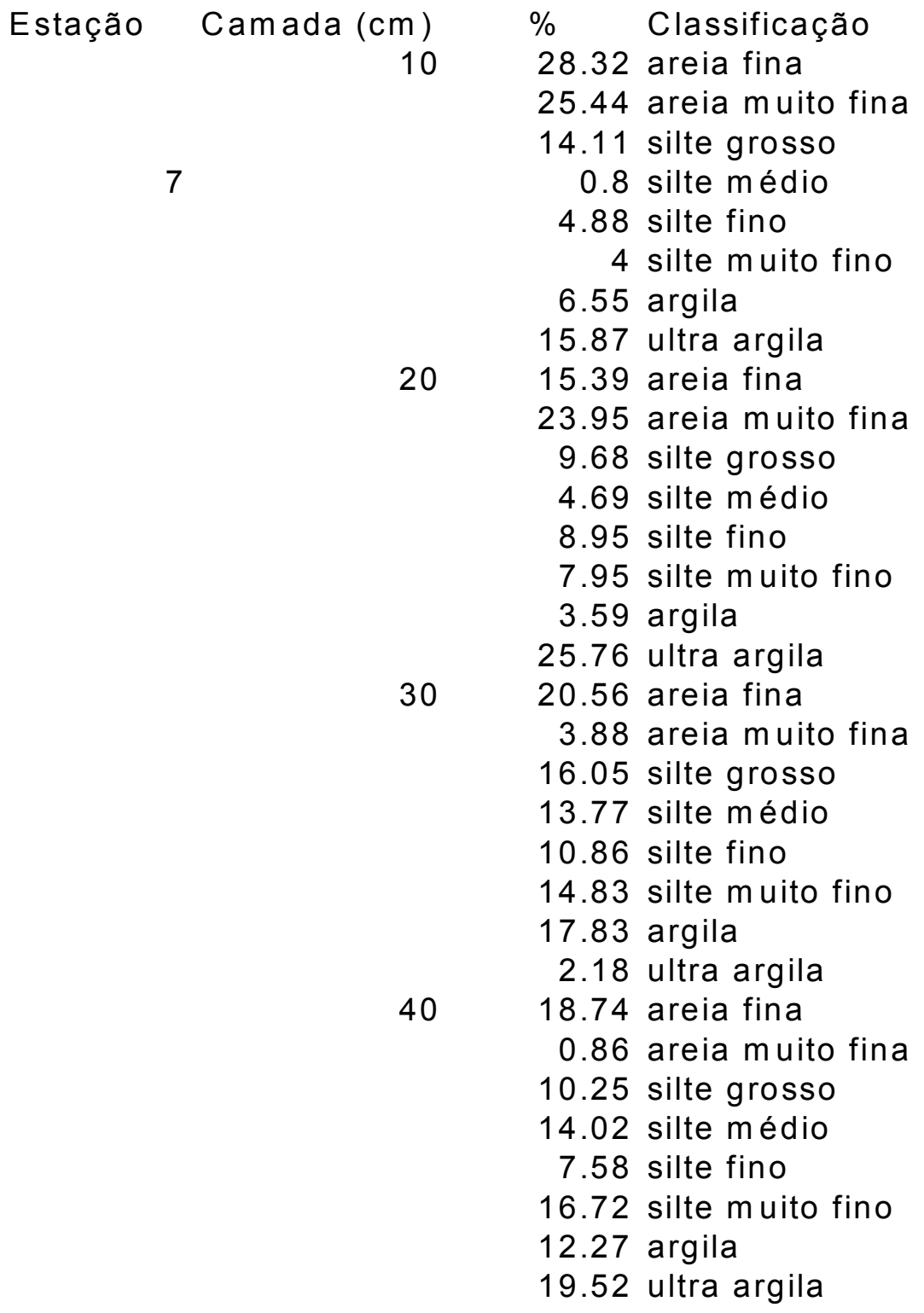




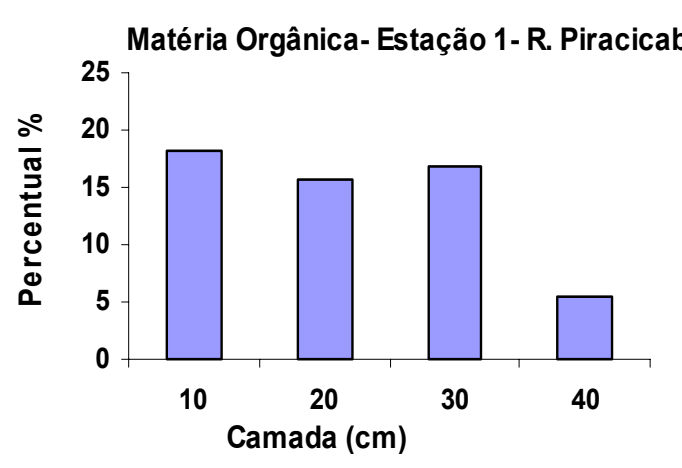

Matéria Orgânica- Estação 2- R. Piracicaba
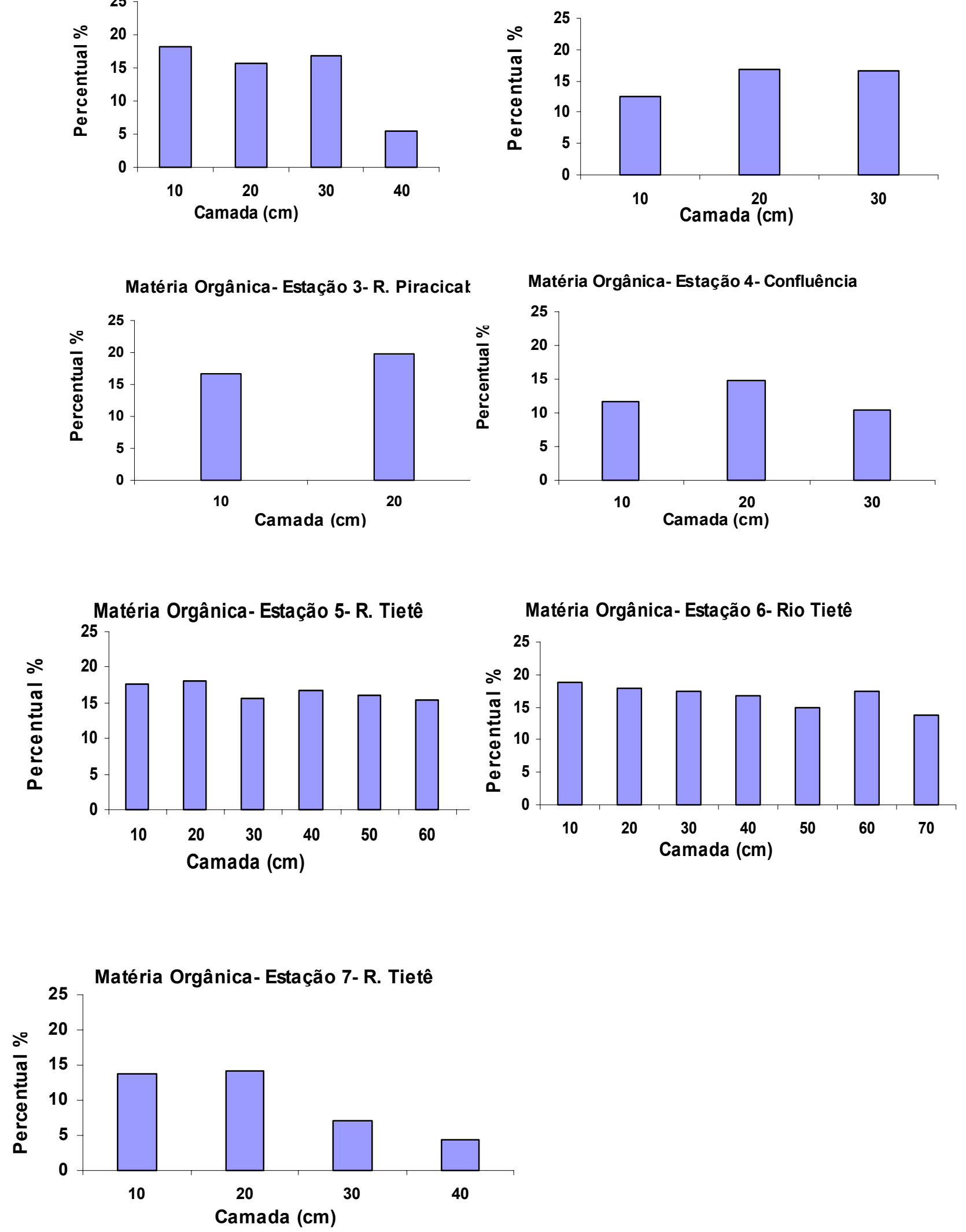

ANEXO 05: Percentual de matéria orgânica no perfil de sedimento, nas diferentes estações de coleta 
